\title{
Hydrogeology, Model Description, and Flow Analysis of the Mississippi River Alluvial Aquifer in Northwestern Mississippi
}

U.S. GEOLOGICAL SURVEY

Water-Resources Investigations Report 01-4035

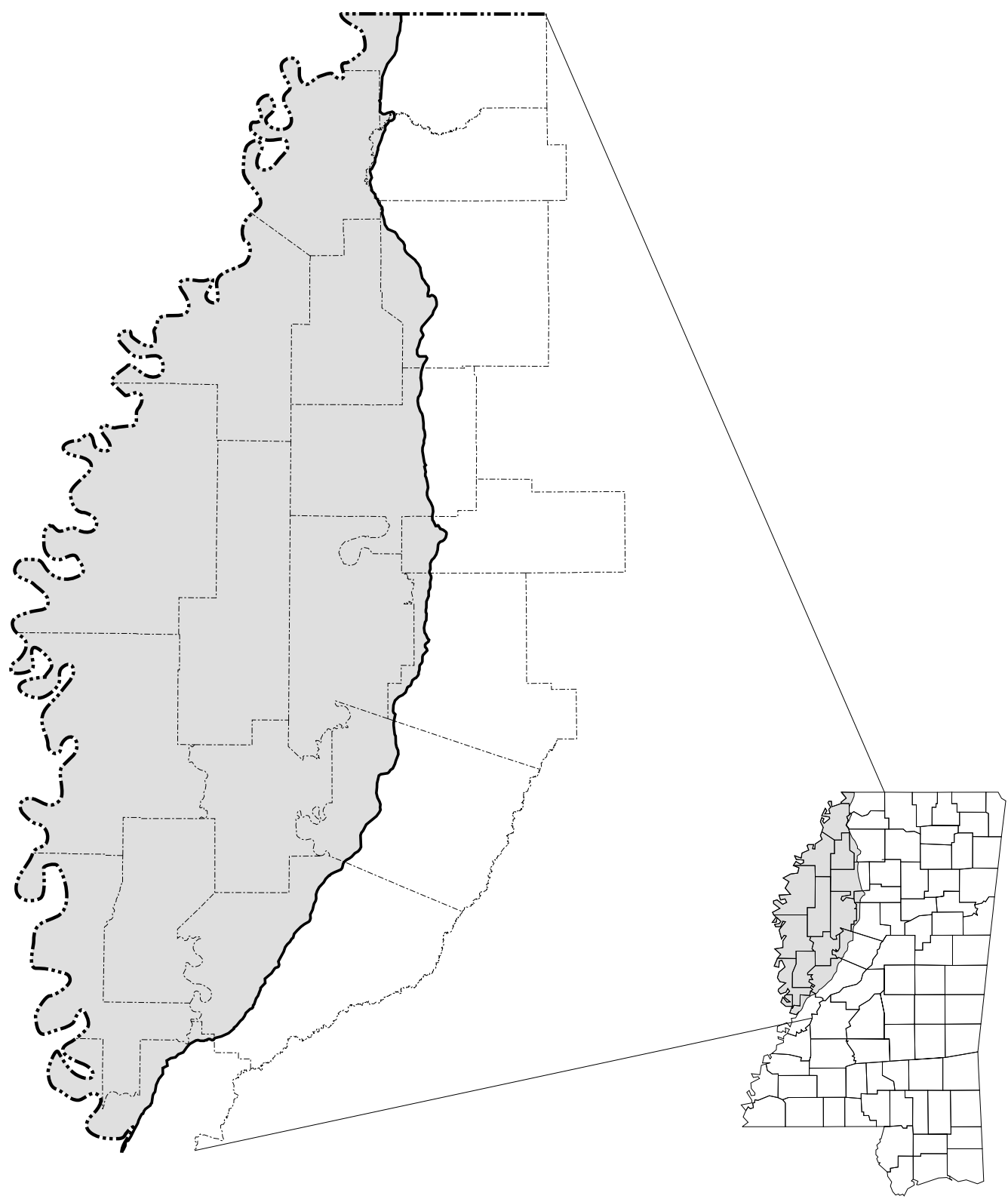

Prepared in cooperation with the MISSISSIPPI DEPARTMENT OF ENVIRONMENTAL QUALITY, OFFICE OF LAND AND WATER RESOURCES 


\section{HYDROGEOLOGY, MODEL DESCRIPTION, AND FLOW ANALYSIS OF THE MISSISSIPPI RIVER ALLUVIAL AQUIFER IN NORTHWESTERN MISSISSIPPI}

by J. Kerry Arthur

U.S. Geological Survey

Water-Resources Investigations Report 01-4035

Prepared in cooperation with the

Mississippi Department of Environmental Quality

Office of Land and Water Resources

Pearl, Mississippi 


\section{U.S. DEPARTMENT OF THE INTERIOR}

GALE A. NORTON, Secretary

U.S. GEOLOGICAL SURVEY

Charles G. Groat, Director

For additional information write to:

District Chief

U.S. Geological Survey, WRD

308 South Airport Road

Jackson, Mississippi 39208-6649
Copies of this report can be purchased from:

U.S. Geological Survey

Branch of Information Services

Box 25286

Denver, Colorado 80225 


\section{CONTENTS}

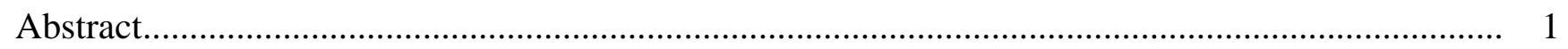

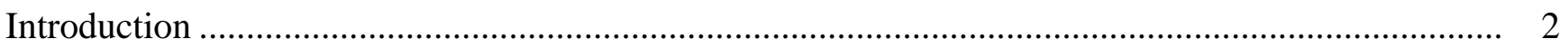

Hydrogeology of the Mississippi River Alluvial Aquifer ................................................. 4

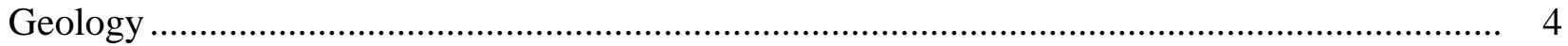

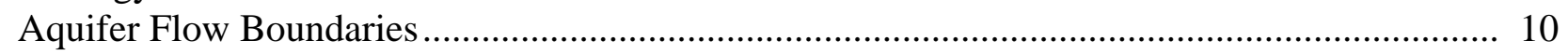

Aquifer Characteristics........................................................................................ 11

Water-Level Measurements, Potentiometric Surfaces, and Direction of Flow ......................... 12

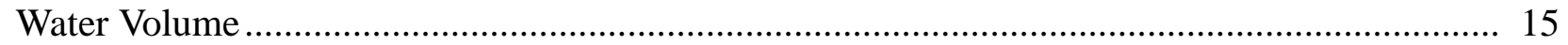

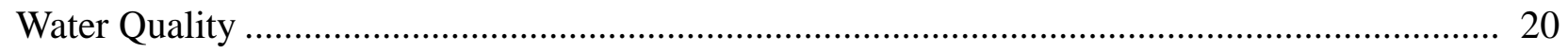

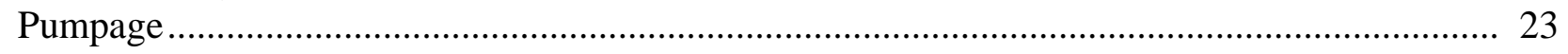

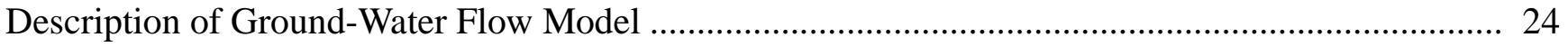

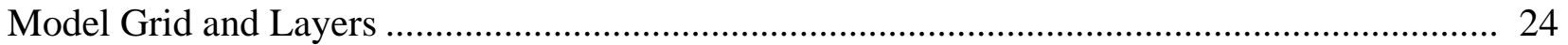

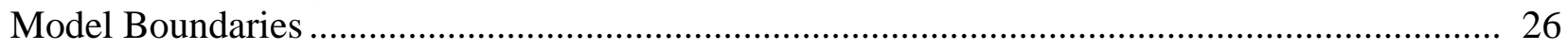

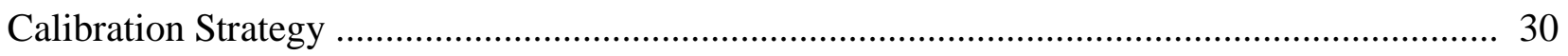

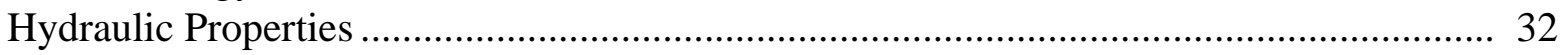

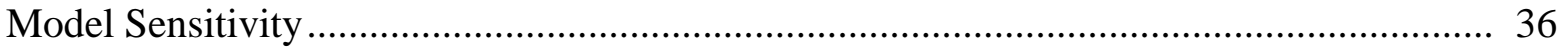

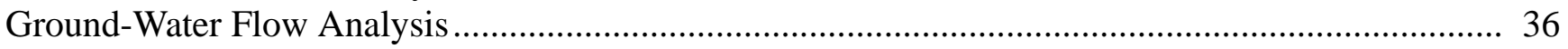

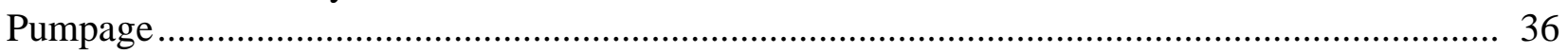

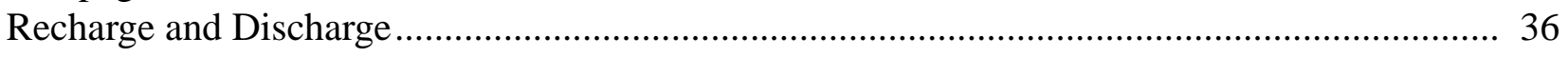

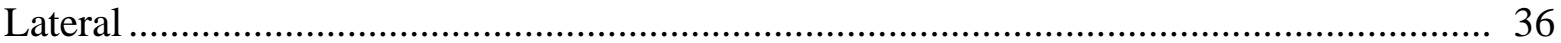

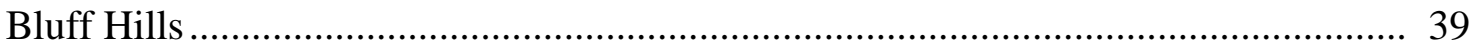

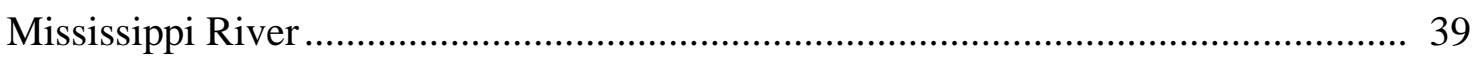

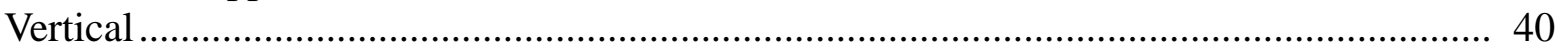

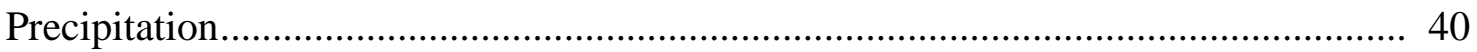

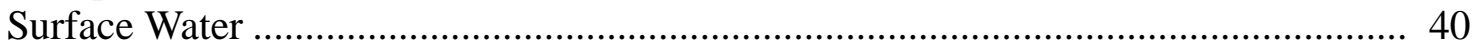

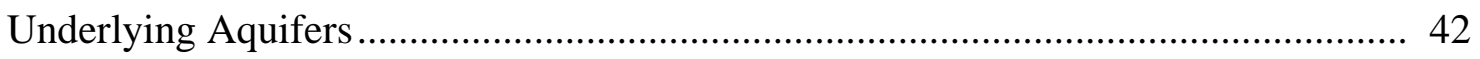

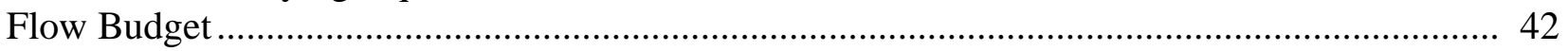

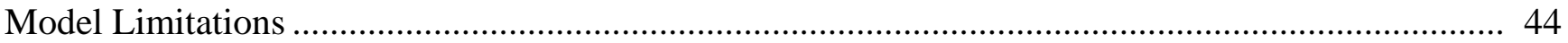

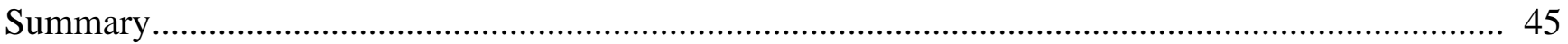

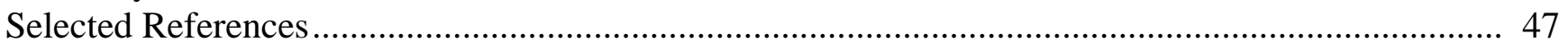

\section{FIGURES}

1-3. Maps showing:

1. Location of study area, northwestern Mississippi ............................................... 3

2. Generalized thickness of the Mississippi River alluvium ......................................... 5

3. Geologic units underlying the Mississippi River alluvial aquifer................................ 7 
4. Geologic sections A-A' and B-B' from west to east across the Delta.....

5. Graph showing relation of water levels in the Mississippi River to water levels in the Mississippi River alluvial aquifer

6. Graph showing average depth to water during spring and fall in the Mississippi River alluvial aquifer

7. Maps showing lowest and highest potentiometric surfaces of the Mississippi River alluvial aquifer since 1980

8. Schematic showing hydrologic and climatic processes in the Delta................................ 16

9. Map showing volume of water in the Mississippi River alluvial aquifer during fall 1999... 17

10. Graph showing estimated rate of gain and loss of water from the Mississippi River alluvial aquifer based on changes in potentiometric surfaces.

11. Graph showing relation of specific conductance to dissolved solids in the Mississippi River alluvial aquifer

12-16. Maps showing:

12. Specific conductance of water in the Mississippi River alluvial aquifer in 1992 and 1998

13. Model grid orientation 25

14. Specified heads at eastern model boundary.

15. Potentiometric surface representing specified heads at the lower boundary (Sparta and Cockfield aquifers)

16. Location of river and lake head-dependent-flux cells (river package) in model

17. Hydrograph showing simulated and measured water levels at selected observation wells completed in the Mississippi River alluvial aquifer

18. Graph showing simulated and measured west-to-east water-level sections across the Delta for spring and fall 1994

19. Map showing observed and simulated spring and fall 1996 potentiometric surfaces of the Mississippi River alluvial aquifer

20. Map showing simulated transmissivity of the Mississippi River alluvial aquifer for fall 1996

21. Graph showing model sensitivity to independent changes in selected calibration parameters

22. Graph showing annual pumpage rate from the Mississippi River alluvial aquifer used in the calibrated model.

23. Map showing areas of concentrated pumpage from the Mississippi River alluvial aquifer in 1996

24. Graph showing relation between average annual stage of the Mississippi River at Greenville, Mississippi, and simulated recharge to the Mississippi River alluvial aquifer from the Mississippi River

25. Graph showing simulated areal recharge to the Mississippi River alluvial aquifer, 1988-96

26. Graph showing simulated recharge to the Mississippi River alluvial aquifer from surfacewater bodies within the Delta

27. Map showing area where water levels in underlying aquifers are greater than water levels in the Mississippi River alluvial aquifer

28. Graph showing average flow budget of the Mississippi River alluvial aquifer for the simulation period (1988-96) 


\section{TABLES}

1. Description of the geologic units underlying the Mississippi River alluvial aquifer .......... 6

2. Rainfall during 1981-96 at Stoneville, Mississippi ..................................................... 13

3. Average monthly stage, in feet above sea level, at selected gage sites on the Mississippi River, 1988-96.

4. Root-mean-square error of simulated water levels in the Mississippi River alluvial aquifer

5. Summary of the principal hydraulic values used in the calibrated model

\section{CONVERSION FACTORS AND VERTICAL DATUM}

\begin{tabular}{|c|c|c|}
\hline Multiply & By & To obtain \\
\hline \multicolumn{3}{|c|}{ Length } \\
\hline inch (in.) & 2.54 & centimeter \\
\hline inch (in.) & 25.4 & millimeter \\
\hline foot $(\mathrm{ft})$ & 0.3048 & meter \\
\hline mile (mi) & 1.609 & kilometer \\
\hline \multicolumn{3}{|c|}{ Area } \\
\hline acre & 4,047 & square meter \\
\hline foot squared per day $\left.\left(\mathrm{ft}^{2} / \mathrm{d}\right)\right)$ & 0.09290 & square meter per day \\
\hline square mile $\left(\mathrm{mi}^{2}\right)$ & 2.590 & square kilometer \\
\hline \multicolumn{3}{|c|}{ Volume } \\
\hline gallon (gal) & 3.785 & liter \\
\hline gallon (gal) & 0.003785 & cubic meter \\
\hline gallon (gal) & 3.785 & cubic decimeter \\
\hline \multicolumn{3}{|c|}{ Flow rate } \\
\hline cubic foot per second $\left(\mathrm{ft}^{3} / \mathrm{d}\right)$ & 0.02832 & cubic meter per second \\
\hline foot per second $(\mathrm{ft} / \mathrm{s})$ & 0.3048 & meter per second \\
\hline foot per day $(\mathrm{ft} / \mathrm{d})$ & 0.3048 & meter per day \\
\hline foot per year (ft/yr) & 0.3048 & meter per year \\
\hline gallon per minute (gal/min) & 0.06308 & liter per second \\
\hline million gallons per day $(\mathrm{Mgal} / \mathrm{d})$ & 0.04381 & cubic meter per second \\
\hline inch per year (in/yr) & 25.4 & millimeter per year \\
\hline \multicolumn{3}{|c|}{ Hydraulic conductivity } \\
\hline foot per day $(\mathrm{ft} / \mathrm{d})$ & 0.3048 & meter per day \\
\hline \multicolumn{3}{|c|}{ Hydraulic gradient } \\
\hline foot per mile (ft/mi) & 0.1894 & meter per kilometer \\
\hline
\end{tabular}


Temperature in degrees Celsius $\left({ }^{\circ} \mathrm{C}\right)$ may be converted to degrees Fahrenheit $\left({ }^{\circ} \mathrm{F}\right)$ as follows:

$$
{ }^{\circ} \mathrm{F}=\left(1.8 \times{ }^{\circ} \mathrm{C}\right)+32
$$

Temperature in degrees Fahrenheit $\left({ }^{\circ} \mathrm{F}\right)$ may be converted to degrees Celsius $\left({ }^{\circ} \mathrm{C}\right)$ as follows:

$$
{ }^{\circ} \mathrm{C}=\left({ }^{\circ} \mathrm{F}-32\right) / 1.8
$$

Sea level: In this report, "sea level" refers to the National Geodetic Vertical Datum of 1929 (NGVD of 1929) — a geodetic datum derived from a general adjustment of the first-order level nets of both the United States and Canada, formerly called Sea Level Datum of 1929.

Altitude, as used in this report, refers to distance above or below sea level.

*Transmissivity: The standard unit for transmissivity is cubic foot per day per square foot times foot of aquifer thickness $\left[\left(\mathrm{ft}^{3} / \mathrm{d}\right) / \mathrm{ft}^{2}\right] \mathrm{ft}$. In this report, the mathematically reduced form, foot squared per day $\left(\mathrm{ft}^{2} / \mathrm{d}\right)$, is used for convenience.

Specific conductance is given in microsiemens per centimeter at 25 degrees Celsius $(\mu \mathrm{S} / \mathrm{cm}$ at $\left.25^{\circ} \mathrm{C}\right)$.

Concentrations of chemical constituents in water are given either in milligrams per liter $(\mathrm{mg} / \mathrm{L})$, micrograms per liter $(\mu \mathrm{g} / \mathrm{L})$, or picograms per kilogram of water $(\mathrm{pg} / \mathrm{kg})$.

1 liter of water by volume is approximately 1 kilogram by mass.

1,000 grams $(\mathrm{g})=1$ kilogram $(\mathrm{kg})$

1,000 milligrams $(\mathrm{mg})=1$ gram

1,000 micrograms $(\mu \mathrm{g})=1$ milligram 


\title{
Hydrogeology, Model Description, and Flow Analysis of the Mississippi River Alluvial Aquifer in Northwestern Mississippi
}

\author{
By J. Kerry Arthur
}

\section{ABSTRACT}

The Mississippi River alluvial aquifer underlies a 7,000-square-mile area of the Mississippi River alluvial plain in northwestern Mississippi, an area locally known as the Delta. The alluvial aquifer is the most heavily pumped aquifer in Mississippi, and wells yielding more than 2,000 gallons per minute are common. About 98 percent of the pumpage from the alluvial aquifer is for agriculture. The sand and gravel that form the alluvial aquifer averages about 110 feet in thickness. The aquifer is confined over most of the Delta, and the upper confining unit averages about 25 feet in thickness. The average depth to water in the alluvial aquifer during fall 1999 was about 25 feet.

The alluvial aquifer receives lateral recharge at the western boundary from the Mississippi River and at the eastern boundary from aquifers that directly underlie the Bluff Hills. The alluvial aquifer receives water vertically from precipitation, internal streams and lakes, and locally from the Cockfield and Sparta aquifers where they directly underlie the alluvial aquifer. The alluvial aquifer also discharges water to the underlying aquifers, and during extended periods with no surface runoff, to the Mississippi River and to the internal streams and lakes. The magnitude of recharge from the Mississippi River, precipitation, and internal lakes and streams can vary greatly depending upon hydrologic and climatic conditions.
The U.S. Geological Survey modular threedimensional finite-difference ground-water flow model, MODFLOW, was used to simulate the Mississippi River alluvial aquifer flow system in northwestern Mississippi. The model uses one layer with a rectangular-grid and 1-mile square cells to represent the alluvial aquifer. The model was calibrated and verified by using spring and fall water-level measurements from January 1988 through December 1996. The values of selected model calibration-derived parameters for the alluvial aquifer are hydraulic conductivity, 425 feet per day; specific yield, 0.32 ; and storage coefficient, 0.016 .

The model showed that the aquifer lost water from storage at an average rate of 404 cubic feet per second during the 9-year simulation period. During this period, the average pumpage rate was 1,270 million gallons per day $(1,980$ cubic feet per second). Simulated areal recharge from precipitation averaged 2.6 inches per year ( 1,360 cubic feet per second). Vertical recharge from the internal streams and lakes and lateral recharge from aquifers underlying the Bluff Hills averaged 113 and 108 cubic feet per second, respectively. Model results indicated that net recharge from the Mississippi River and from aquifers directly underlying the alluvial aquifer was small. 


\section{INTRODUCTION}

The Mississippi River alluvial aquifer in northwestern Mississippi is part of the large aquifer system formed by the Mississippi River and its tributaries that underlies the Mississippi River alluvial plain in parts of six States in the Mississippi embayment. In northwestern Mississippi, the Mississippi alluvial plain is a lensshaped area that includes all or part of 19 counties covering about 7,000 square miles (fig. 1). Locally this area is known as the Delta. The Delta extends from the Mississippi-Tennessee border at Memphis, Tennessee, about 200 miles southward to Vicksburg, Mississippi. At the widest point, about midway between Memphis and Vicksburg, the Delta is about 70 miles wide. The western extent of the Delta is the Mississippi River, and the eastern extent is the loess-capped Bluff Hills. The Delta land surface has very little relief, and slopes gently at about $1 / 2$ foot per mile from about 200 feet above sea level at the northern end near Memphis to about 80 feet above sea level near Vicksburg. The Bluff Hills escarpment provides an abrupt transition in topography from the alluvial plain by rising 100 to 200 feet above the alluvial plain. The present day Mississippi River channel, which generally follows the western Mississippi State boundary in the Delta, penetrates, in most locations, about the entire thickness of the Mississippi alluvial plain. The river is a hydraulic as well as a physical boundary of the Delta. The Yazoo-YalobushaTallahatchie-Yocona-Coldwater River system drains the eastern part of the Delta and a large upland area to the east of the alluvial plain. The Sunflower-Bogue Phalia River system drains most of the central and western part of the alluvial plain outside of the Mississippi River levee system. All the water drained by the Sunflower-Bogue Phalia River system originates within the Delta and flows into the Yazoo River just north of Vicksburg. The Delta has many oxbow lakes that store large quantities of water, but the largest of these crescent-shaped lakes are old meanders of the Mississippi River. Five of the largest lakes are Horn Lake in DeSoto County, Moon Lake in Coahoma County, Lake Bolivar in Bolivar County, Lake Washington in Washington County, and Eagle Lake in Warren County (fig. 1).

The climate in the Delta is humid subtropical. Average annual temperature ranges from 62 degrees Fahrenheit near Memphis to 66 degrees Fahrenheit near Vicksburg (Krinitzsky and Wire, 1964). Average annual precipitation in the Delta is about 52 inches with very little spatial variation. Most of the precipitation, about 62 percent, occurs in the winter and spring. The fall season has the least precipitation comprising about 17 percent of the annual total.

The Mississippi River alluvial aquifer (hereafter referred to as the alluvial aquifer) is the most heavily pumped aquifer in Mississippi and supplies most of the water used for agriculture and industry in the Mississippi Delta. All the municipal and water association withdrawals in the Delta, except for the city of Vicksburg and the Eagle Lake Water Association, are derived from the deeper Tertiary aquifers. The city of Vicksburg uses the alluvial aquifer as its municipal water source, but the city's annual use is less than 1 percent of the total water pumped from the alluvial aquifer. About 98 percent of the withdrawal from the alluvial aquifer is for agriculture. The Delta is the economic center for agriculture in Mississippi, producing 99 percent of the rice, 96 percent of the catfish, 79 percent of the soybeans, and 72 percent of the cotton grown in the State. Water required for catfish and rice production accounts for most of the ground-water demand in the Delta. Humphreys, Sunflower, and Leflore Counties contain more than half of the catfish pond acreage in the Delta. Bolivar, Sunflower, and Washington Counties account for more than half of the rice produced in the Delta. Irrigation of cotton, soybeans, and corn during periods of deficient rainfall also contributes to the demand for water from the alluvial aquifer.

Since fall 1980, personnel from the U.S. Geological Survey (USGS), the Mississippi Department of Environmental Quality, Office of Land and Water Resources (OLWR), and the Yazoo Mississippi Delta Joint Water Management District (YMD) have made water-level measurements at more than 300 observation wells in the alluvial aquifer during the spring and fall of each year except in 1987 and 1988 when only fall measurements were made. These measurements indicate that water levels in the alluvial aquifer fluctuate seasonally with the highest levels occurring in the spring and the lowest levels occurring in the fall. The magnitude of the fluctuation depends upon rainfall, hydrologic conditions, and the amount of water pumped from the aquifer between the measuring periods. Also, the water-level measurements indicate a decreasing trend in the total volume of water in the alluvial aquifer since 1980 .

From 1995 to 2000, the USGS, in cooperation with the OLWR, conducted a study to better understand the hydrogeology of the Mississippi River alluvial aquifer flow system in northwestern Mississippi and to 


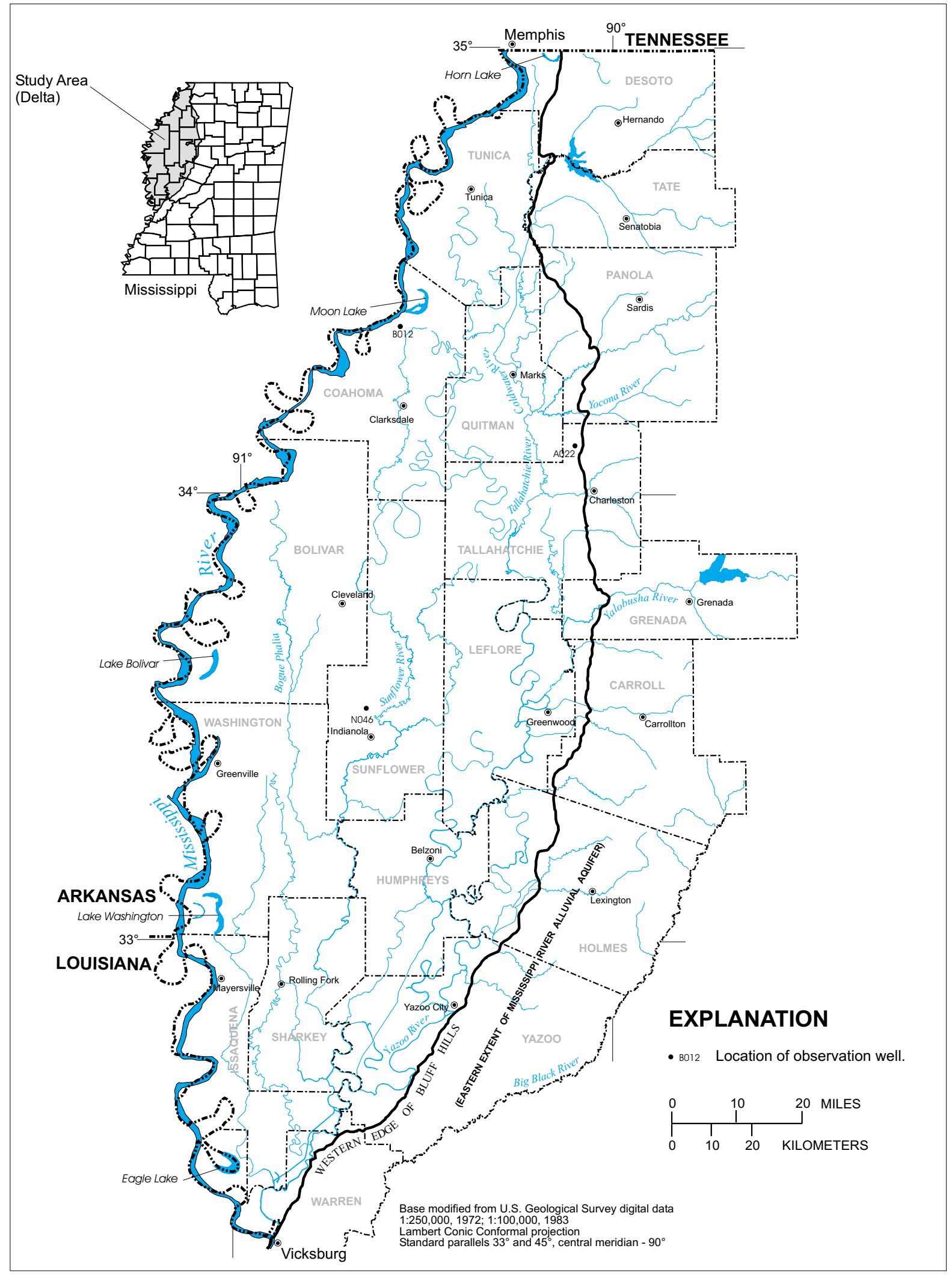

Figure 1. Location of study area, northwestern Mississippi. 
construct a computer model of the flow system. The study of the hydrogeology and flow analysis of the alluvial aquifer may provide better insight into the recharge/discharge processes for the aquifer, and help determine the effects that different hydrologic conditions and pumpage have on the capacity of the aquifer to yield sufficient quantities of water for continuing agricultural and industrial growth in the Delta. Hydrologic information and field assistance was provided by the OLWR, the YMD, and the Natural Resources Conservation Service. This report describes the hydrogeology, the computer model, and the flow system of the alluvial aquifer as determined by field investigations, data review, and computer modeling results.

\section{HYDROGEOLOGY OF THE MISSISSIPPI RIVER ALLUVIAL AQUIFER}

The Mississippi River alluvial aquifer flow system is a dynamic, rapidly responding flow system. The flow system is probably the most complex of the major aquifers in Mississippi with regard to changes in recharge and natural discharge as a result of fluctuations in hydrologic and climatic conditions. The aquifer is recharged by water from the Mississippi River and rivers within the Delta during periods of high river stages; by natural and man-made lakes, both inside and outside the Mississippi River levee system; by aquifers and sediments abutting the eastern edge of the alluvial plain; by rainfall that does not run off, evaporate, or transpire; and by water in aquifers directly underlying the alluvial aquifer. The aquifer discharges water to the Mississippi River and to streams within the Delta during periods of low river stages; to lakes during the summer and fall when lake levels are low; to aquifers underlying the alluvial aquifer when heads in the alluvial aquifer are greater than heads in the underlying aquifer; and to pumpage for agricultural, industrial, and municipal uses. The components of recharge and discharge vary greatly in time and space depending upon the depositional environment and climatic and economic conditions, not only within the Delta but also outside the Delta area.

The alluvial aquifer consists of sand and gravel deposits of Quaternary age. The alluvial sediments were deposited in an entrenchment into Tertiary-age rocks in the Mississippi River Valley. Pleistocene glaciation caused a lowering of sea level and increased stream gradients, which resulted in incisement of the Mississippi River Valley as water from the melting gla- ciers rushed toward the Gulf of Mexico. The valley was eroded more than 100 feet deeper than the present surface of the alluvial plain (Krinitzsky and Wire, 1964). As sea level rose, stream gradients decreased and the entrenched valley was filled with sediment. Since the initial formation of the alluvial plain, the deposition of eroded Coastal Plain deposits and the continued erosion and deposition of materials by the Mississippi River and other streams within the alluvial plain has resulted in a diverse sequence of deposits forming the alluvial plain.

\section{Geology}

The Mississippi River alluvium in northwestern Mississippi was deposited on an erosional Tertiary-age surface having a system of north-south valleys (Fisk, 1944). The average thickness of the alluvium in Mississippi is about 135 feet. Locally, the thickness ranges from 75 to greater than 200 feet (Arthur and Strom, 1996); throughout most of the Delta, the thickness ranges from 120 to 160 feet (fig. 2). The coarsest sediments, consisting of gravel and coarse sand, generally occur at or near the base of the alluvium and tend to be thicker where the alluvium is thickest. The finer clay, silt, and sand sediments generally occur in the upper part of the alluvium, but these sediments can occur to varying degrees throughout the entire thickness of the alluvium. The sand and gravel that form the alluvial aquifer average about 110 feet in thickness. The aquifer is generally thickest in the central part of the alluvial plain and thinnest adjacent to the Bluff Hills and in west-central Washington County (Arthur and Strom, 1996). The various combinations of sand, silt, and clay that occur near the surface of the alluvial plain make up a low permeability topstratum (Fisk, 1944). The topstratum consists largely of alternating interbedded silty sand and silty clay of natural levees along stream channels and sand bars. The topstratum also consists of clay plugs, which were formed by the deposition of finegrained, relatively impermeable sediments in abandoned river channels and sloughs. The topstratum, which will be referred to in this report as the upper confining unit, overlies the alluvial aquifer throughout about 99 percent of the Delta. Over most of the Delta, where present, the upper confining unit ranges from 10 to 50 feet thick and averages about 25 feet in thickness. A detailed description of the spatial distribution of the thickness of the upper confining unit and sand and gravel in the Mississippi River alluvium in northwest- 


\section{EXPLANATION}

-140 - Line of equal thickness of the alluvium. Interval 20 feet

Eastern extent of Mississippi River alluvial aquifer (study area)
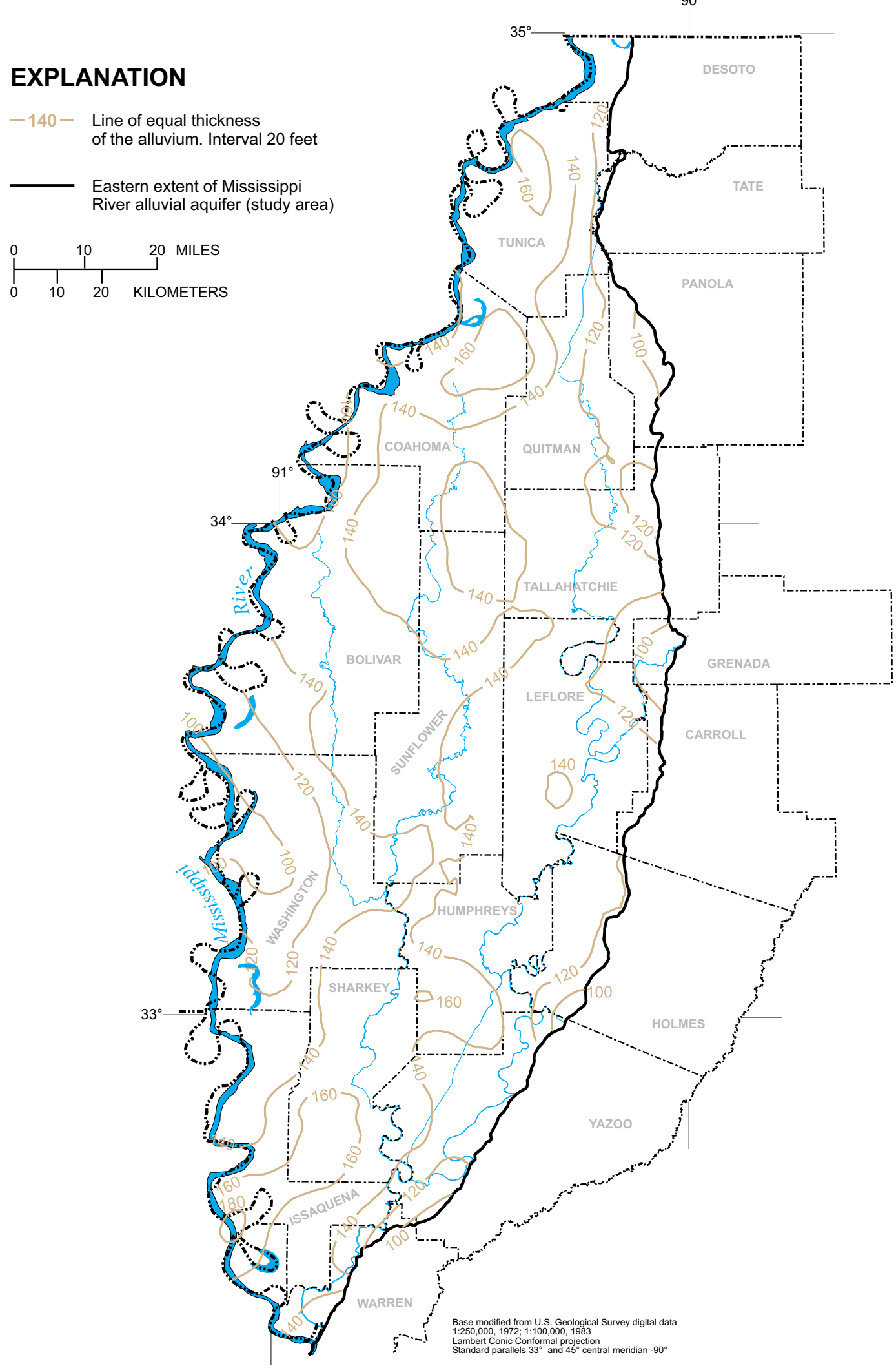

Figure 2. Generalized thickness of the Mississippi River alluvium. 
ern Mississippi is given in reports by Arthur (1994) and by Arthur and Strom (1996).

The geologic units of Tertiary age underlying the Mississippi River alluvial aquifer dip 15 to 40 feet per mile to the west in the northern part of the Delta and to the southwest in the southern part of the Delta toward the axis of the Mississippi River embayment trough.

The axis of the embayment approximately parallels the Mississippi River. The underlying units from the oldest to the youngest are as follows: Zilpha Clay, Sparta Sand, Cook Mountain Formation, Cockfield Formation, Yazoo Clay, and the Forest Hill Formation. A map (modified from Jennings, 2001) showing the areas where these geologic units subcrop the alluvial aquifer is shown in figure 3 .

Two geologic sections (modified from Jennings, 2001) showing the relation of these units to each other and to the overlying alluvial aquifer are shown in figure 4. The sediments of these units in contact with the alluvial aquifer consist of unconsolidated sand, silt, and clay beds of varying thickness. In areas where the underlying-unit contact consists of clay or silty clay, the contact impedes the vertical movement of water between the alluvial aquifer and the underlying aquifer. The Zilpha Clay and Yazoo Clay are low permeability marine clays. The Cook Mountain Formation is mostly clay, but has substantial sand thickness in the northern half of the Delta. The Cockfield Formation and the Sparta Sand are mostly sand with clay beds separating individual sand beds. The sand beds within the Cockfield and Sparta form two of the major aquifers that supply drinking water in the State. In areas where sand beds of the Cockfield Formation or Sparta Sand are in contact with the alluvial aquifer, hydraulic connection exists between the alluvial aquifer and the deeper aquifer. The Forest Hill Formation underlies the alluvial aquifer in a small area (about 3 square miles) in Warren County at the edge of the Bluff Hills. The Forest Hill Formation consists mostly of sand and clay and is a minor aquifer in Mississippi. The geologic units underlying the Mississippi River alluvial aquifer are described in table 1 .

Table 1. Description of the geologic units underlying the Mississippi River alluvial aquifer

\begin{tabular}{|c|c|c|c|}
\hline Geologic unit & $\begin{array}{l}\text { Maximum thickness } \\
\text { (feet) }\end{array}$ & Lithology & $\begin{array}{l}\text { Water-bearing } \\
\text { characteristics }\end{array}$ \\
\hline Forest Hill Formation & 50 & Sand and clay & $\begin{array}{l}\text { Minor aquifer } \\
\text { (Gandi, 1979). }\end{array}$ \\
\hline Yazoo Clay & 500 & Clay & Not an aquifer. \\
\hline Cockfield Formation & 500 & Sand and clay & $\begin{array}{l}\text { Major aquifer } \\
\text { (Spiers, 1977). In } \\
\text { the Greenville area, water } \\
\text { levels are lower than in } \\
\text { the alluvial aquifer. } \\
\text { In other areas, water } \\
\text { levels are about the } \\
\text { same as in the alluvial } \\
\text { aquifer. }\end{array}$ \\
\hline Cook Mountain Formation & 170 & $\begin{array}{l}\text { Clay and sandy clay } \\
\text { Mostly sandy clay } \\
\text { in northern part of } \\
\text { Delta }\end{array}$ & Not an aquifer. \\
\hline Sparta Sand & 700 & Sand and clay & $\begin{array}{l}\text { Major aquifer } \\
\text { (Newcome, 1976). Water } \\
\text { levels are about the same as } \\
\text { in the alluvial aquifer except } \\
\text { near Bluff Hills where they are } \\
\text { higher. }\end{array}$ \\
\hline Zilpha Clay & 150 & $\begin{array}{l}\text { Clay; becomes } \\
\text { sandy northward }\end{array}$ & Not an aquifer. \\
\hline
\end{tabular}




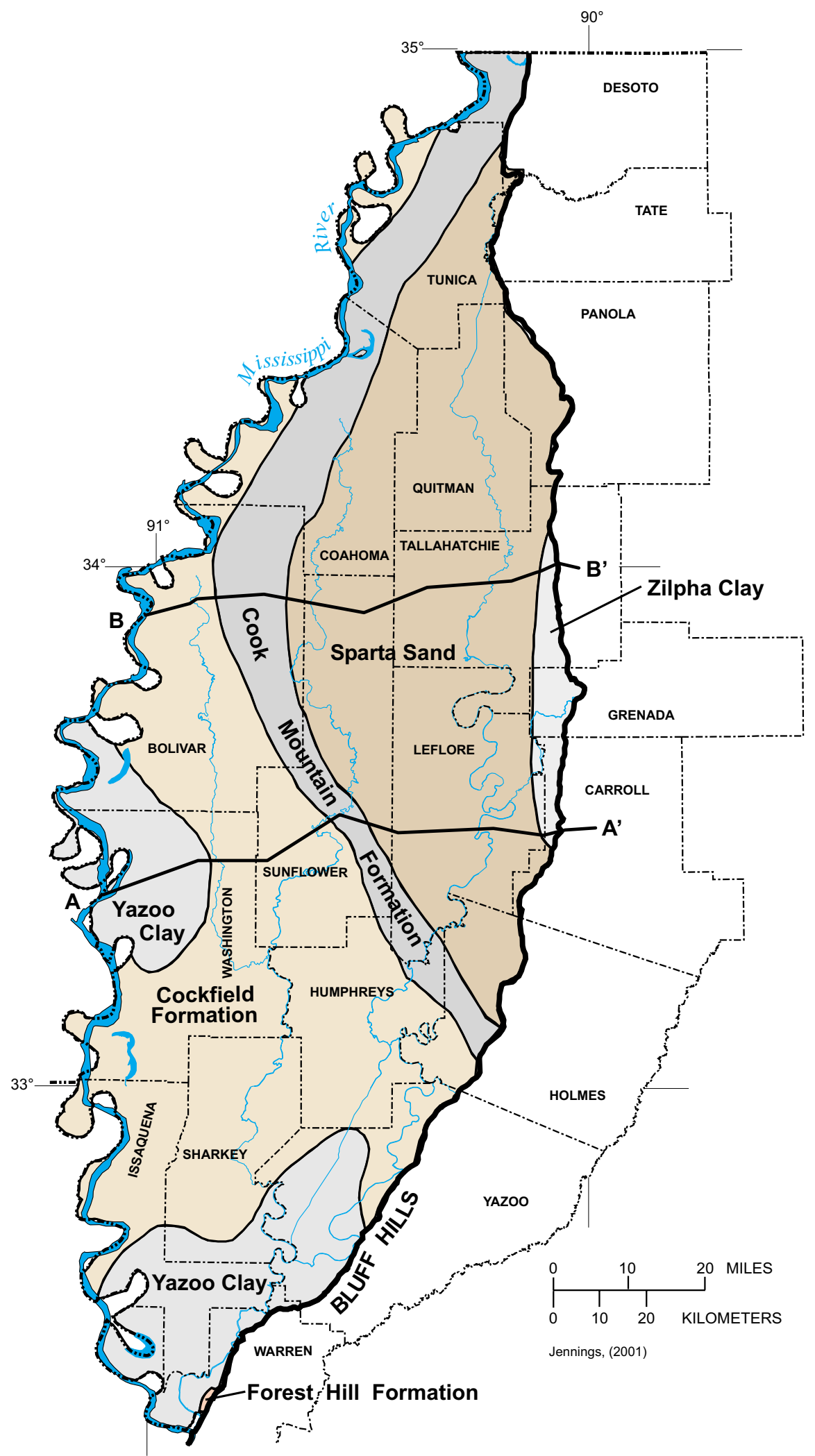

Figure 3. Geologic units underlying the Mississippi River alluvial aquifer. 


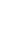

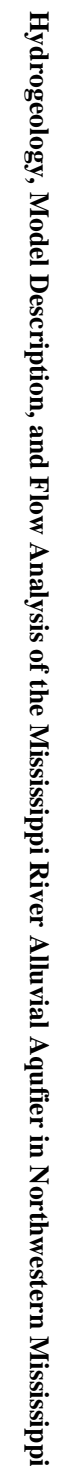

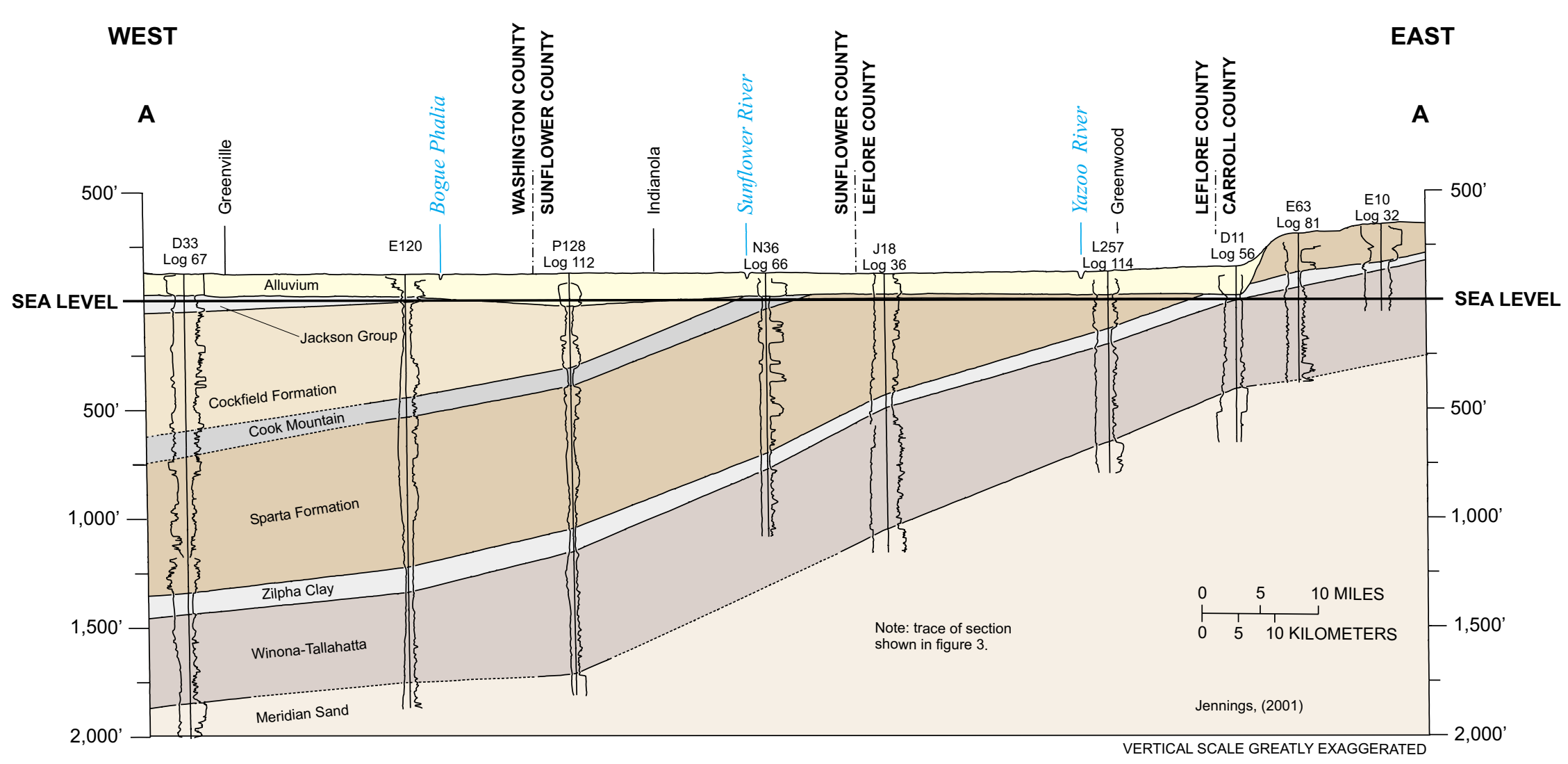

Figure 4a. Geologic section A-A' from west to east across the Delta. 


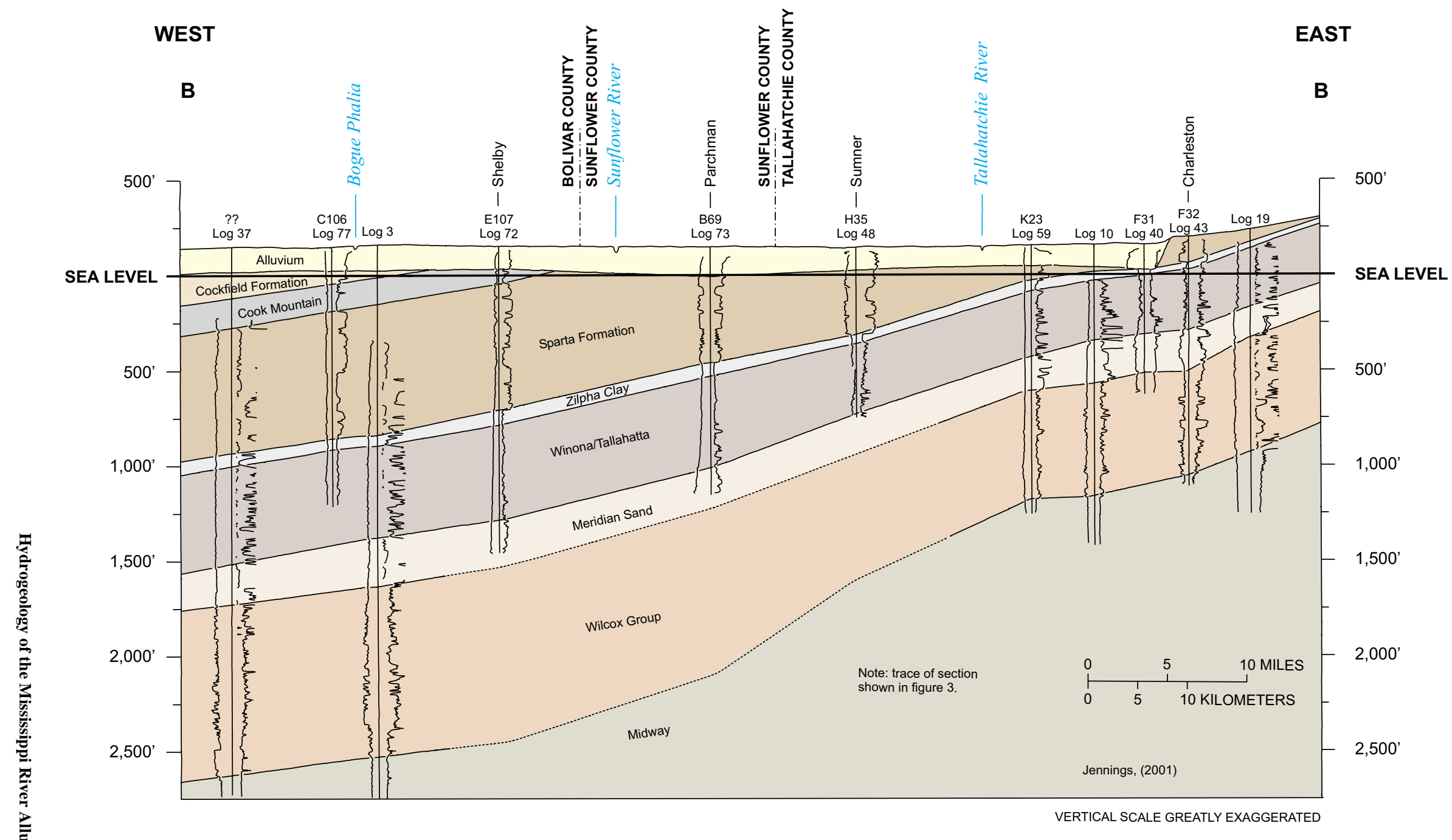

Figure 4b. Geologic section B-B' from west to east across the Delta. 


\section{Aquifer Flow Boundaries}

The Mississippi River alluvial aquifer in northwestern Mississippi functions as an independent flow system from the Mississippi River alluvial aquifer west of the Mississippi River in Arkansas and Louisiana. In most locations, the present day Mississippi River channel penetrates nearly the entire thickness of the alluvium and serves as a hydraulic boundary that separates flow in the alluvial aquifer east of the river from flow in the alluvial aquifer west of the river. Stresses applied to the Mississippi River alluvial aquifer on the western side of the river have no effect on the alluvial aquifer underlying the Delta in Mississippi. The Mississippi River, the western flow boundary, serves as a variablehead hydraulic barrier and both a recharge source and discharge area for the alluvial aquifer. When the Mississippi River is at a high stage, water flows from the river into the aquifer; conversely, when the river is at a low stage, water flows from the aquifer to the river (fig. 5). The stage of the Mississippi River can vary as much as 50 feet from extreme flood to severe drought conditions. As a result, the alluvial aquifer water levels adjacent to the river are buffered within this range of river-stage changes, and the aquifer is recharged and drained locally by the Mississippi River seasonally. However, because of the cyclic recharging and draining of the aquifer adjacent to the river, the net long-term contribution to ground water from the river is probably small compared to the other recharge sources.

The eastern flow boundary of the Mississippi River alluvial aquifer occurs at the western edge of the loess-capped Bluff Hills. The western edge of the Bluff Hills marks the eastern extent of the Mississippi River alluvial plain and the alluvial aquifer (fig. 1). The Mississippi River valley is incised into the underlying Tertiary-age deposits along the eastern edge of the Delta adjacent to the Bluff Hills (fig. 2). At the eastern edge of the Delta, along the contact between the alluvial aquifer and the Cockfield and Sparta aquifers, a substantial upward hydraulic gradient between the Tertiary aquifers and the alluvial aquifer produces a correspondingly large lateral and upward flow into the alluvial aquifer. The water-bearing units underlying the western edge of the Bluff Hills are a major recharge source for the Mississippi River alluvial aquifer.

The upper boundary of the alluvial aquifer is the low permeability topstratum, which is present over about 99 percent of the Delta. The topstratum consists of interbedded clay, silt, and sand. A detailed description of the topstratum (upper confining unit) is given by Arthur (1994). Where present, the topstratum impedes vertical recharge to the alluvial aquifer from precipitation and from surface-water bodies (rivers, lakes, ponds, and agricultural applications). About 20 inches of the annual precipitation is runoff, leaving about 32 inches for evaporation, transpiration by vegetation, and replenishment of the ground-water reservoir. Usually only about 5 percent of the total rainfall (about 2.6 inches) replenishes the ground-water reservoir (Krinitzsky and Wire, 1964). Infiltration of precipitation is the chief source of recharge to the alluvial aquifer (Boswell and others, 1968).

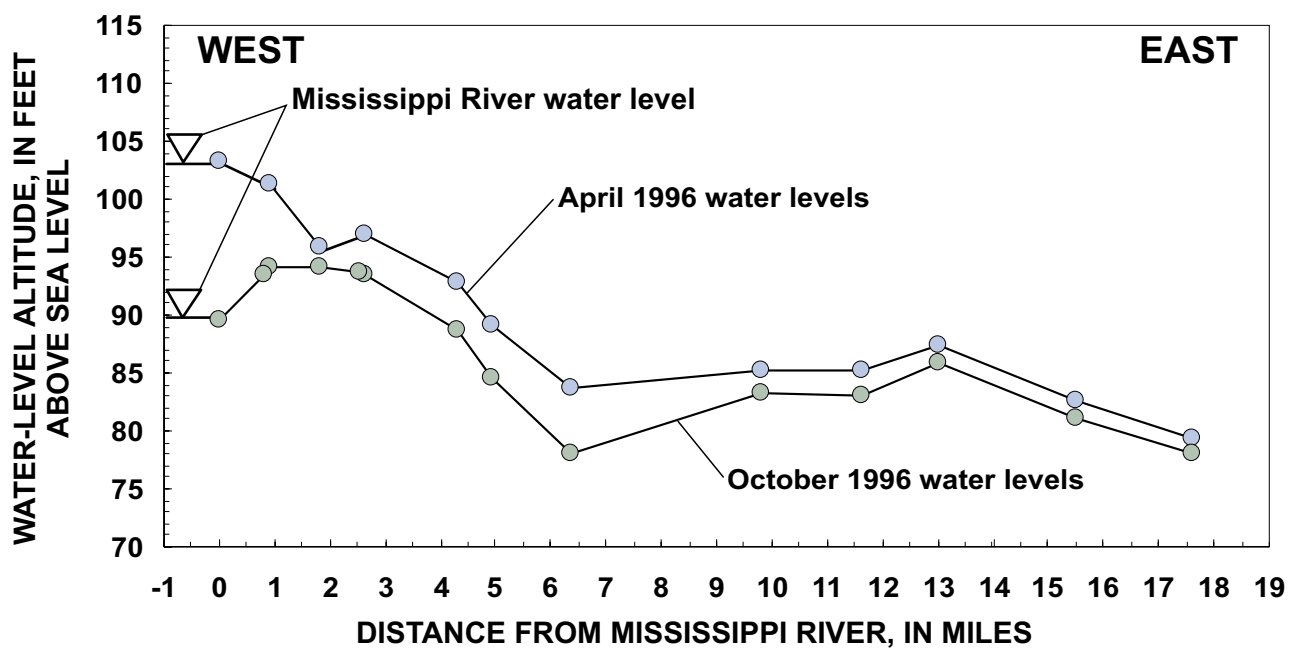

Figure 5. Relation of water levels in the Mississippi River to water levels in the Mississippi River alluvial aquifer. 
The lower flow boundary of the Mississippi River alluvial aquifer is the contact between the underlying Tertiary-age deposits and the alluvial aquifer (fig. 2). The Sparta Sand and Cockfield Formation underlie most of the alluvial aquifer in the Delta. In these areas, flow between the alluvial aquifer and the two underlying aquifers is probable. The most likely area for flow upward into the alluvial aquifer is near the eastern edge of the Delta where water levels in the underlying aquifers are higher than in other parts of the Delta. The most likely area for flow from the alluvial aquifer downward into the underlying unit is in the western part of the Delta where the Cockfield Formation underlies the alluvial aquifer, and where heads in the Cockfield aquifer are lower than the heads in the alluvial aquifer. In areas where the Yazoo Clay, Zilpha Clay, and Cook Mountain Formation underlie the alluvial aquifer, the low permeability characteristics of these deposits impede vertical flow. In recent times, net recharge at the lower boundary is probably small, but could be important locally where the alluvium is in direct contact with the underlying water-bearing sand beds, and where the water level in the alluvial aquifer is lower than the water level in the underlying aquifer. Sumner and Wasson (1990) assumed that flow interaction between the underlying Tertiary aquifers and the alluvial aquifer was negligible during the model simulation period 1981-83, and they simulated the lower boundary as a no-flow boundary. Before extensive development of the Cockfield and Sparta aquifers, water levels in these two underlying aquifers were substantially higher than water levels in the alluvial aquifer, and recharge from the underlying aquifers was probably greater. Predevelopment upward flow from the Cockfield aquifer is indicated by the greater concentration of dissolved solids in the alluvial water in the southwestern part of the Delta.

\section{Aquifer Characteristics}

The Mississippi River alluvial aquifer is capable of storing and yielding large quantities of water almost everywhere in the Delta. The average thickness of the sand and gravel in the alluvial aquifer in the Delta is about 110 feet. Wells in the Delta commonly yield more than 2,000 gallons per minute from the alluvial aquifer.

Aquifer characteristics that indicate the capacity of an aquifer to store and transmit water are specific yield, storage coefficient, hydraulic conductivity, and transmissivity. The specific yield of the aquifer is the volume of water that a unit volume of aquifer material will yield by gravity drainage from a saturated state.

Storage coefficient is the volume of water that an aquifer releases or takes into storage per unit surface area of the aquifer per unit change in head. The size of the storage coefficient depends on whether the aquifer is confined (water level in tightly cased well is above the top of the aquifer) or unconfined (water level is at or below the top of the aquifer). If the aquifer is confined, the storage coefficient is small because the water released from storage when the head declines comes from expansion of the water and from compression of the aquifer. If the aquifer is unconfined, the predominant source of water is by gravity drainage from aquifer material with the decline of head. The storage coefficient of an unconfined aquifer is virtually equal to the specific yield of the aquifer. Hydraulic conductivity is a measure of the ability of the aquifer to transmit water through a unit cross-sectional area of the aquifer in response to a unit hydraulic gradient. Transmissivity is a measure of the ability of an aquifer to transmit water through a unit width of aquifer material in response to a unit hydraulic gradient. Transmissivity is equal to the hydraulic conductivity times the saturated thickness of the aquifer material.

Few aquifer tests are available for the alluvial aquifer in northwestern Mississippi. Slack and Darden (1991) reported the results of six aquifer tests for the alluvial aquifer in the Mississippi Delta. Three tests were conducted in Warren County, two in Washington County, and one in Coahoma County. The storage coefficients for the aquifer tests ranged from 0.0003 to 0.016. Krinitzsky and Wire (1964) reported a specific yield of 0.15 in Tallahatchie County. West of the Mississippi River in Arkansas, the specific yield of the Mississippi River alluvial aquifer is reported to range from 0.27 to 0.38 based on laboratory tests of repacked samples (Krinitzsky and Wire, 1964). The range of transmissivity from the six tests in Mississippi was 12,000 to 51,000 feet squared per day, and the range of hydraulic conductivity was 130 to 400 feet per day. Krinitzsky and Wire (1964) reported a hydraulic conductivity of more than 1,100 feet per day for alluvial aquifer material in Arkansas. 


\section{Water-Level Measurements, Potentiometric Surfaces, and Direction of Flow}

Prior to extensive development of the Mississippi River alluvial aquifer as a source of water for agriculture and industry, water levels in the aquifer were within 10 to 20 feet of land surface over most of the Delta (Brown, 1947). Wells near the Mississippi River were reported to flow when the river was at high stage, as well as some wells adjacent to the Bluff Hills, indicating the aquifer in these locations was under confined conditions. Subsequent to the extensive development of the aquifer (mainly for agriculture), water levels have declined to as much as 45 feet below land surface in localized areas in the central part of the Delta. Outside the heavy use area in the central part of the Delta, water levels in the aquifer average less than 25 feet below land surface, and some wells adjacent to the Mississippi River levee system flow when the Mississippi River is at high stage.

Since 1992, to supplement the spring and fall water-level measurements made by the YMD at more than 300 observation wells, the OLWR has been making monthly water-level measurements at selected observation wells during the fall and winter seasons along three west-to-east sections across the Delta. Water-level measurements indicate that water levels in the alluvial aquifer fluctuate seasonally with the highest water levels occurring during early spring and the lowest water levels occurring during early fall. Since 1980 the fall water levels in the Delta has averaged about 3.7 feet lower than the preceding spring water levels. During the winter, water levels recover, and spring water levels average about 3.5 feet higher than the preceding fall water levels (fig. 6) resulting in about an average decline of less than 0.2 foot per year since 1980. The range of the seasonal fluctuation in water levels is between about 1.0 and 5.5 feet depending on the amount and distribution of rainfall and pumpage.

In summer 1988, rainfall was below average (table 2), and pumpage for agriculture was greater than normal. As a result, the fall 1988 average water level in the alluvial aquifer was the lowest on record (average 24.6 feet below land surface) until fall 1999 when the record average low water level was equaled. Water levels recovered substantially by spring 1989; however, during spring 1989, water levels (average 19.9 feet below land surface) were still below the typical spring levels. During spring and summer 1989, precipitation was above average, and pumpage for agriculture was less than normal. As a result of the wet spring and summer and reduced pumpage during the 1989 growing season, the fall 1989 water levels (average 21.6 feet below land surface) were about equal to fall levels prior to the drought during summer 1988.

Since fall 1980, the regional potentiometric surface of the alluvial aquifer in the Delta was lowest in fall 1988 and fall 1999 and was the highest in spring 1984 (fig. 7). Since fall 1980, the regional potentiometric surface has fluctuated seasonally, but the regional potentiometric surface has declined only about 2 to 3 feet. Locally, the potentiometric surface has declined greater than 30 feet in the central part of the Delta near the Sunflower-Leflore County line and as much as 15 feet in central Humphreys County.

Historically, the regional potentiometric surface of the alluvial aquifer has sloped from north to south, from the west, and from the east toward the Sunflower River, which flows from north to south in the central part of the Delta. The shape of the potentiometric surface indicates that the regional flow direction in the aquifer is composed of two components--a north-tosouth axial flow reflecting the north-to-south slope of the alluvial plain and a periphery-to-interior lateral flow due to the influence of the high-altitude (Bluff Hills) recharge source to the east and the Mississippi River to the west. The shape of the potentiometric surface indicates that the Sunflower and Yazoo Rivers are regional drains for the alluvial aquifer during low river stages. Although the alluvial plain has very little topographic relief, the land surface is about 100 feet lower at the southern part of the Delta near Vicksburg than at the northern part near Memphis, and the land-surface slope is reflected in the regional potentiometric surface of the aquifer. East of the Delta, the water levels in the water-bearing units underlying the Bluff Hills are generally equal to or greater than the altitude of the surface of the Mississippi River alluvial plain. Flow from this high-altitude recharge source is reflected in an east-towest slope of the potentiometric surface toward the central part of the Delta. Flow from the western edge of the Delta is influenced by the Mississippi River.

During the typical 3 to 4 months of the year when the Mississippi River is at a stage higher than the potentiometric surface of the alluvial aquifer adjacent to the river, flow direction is eastward from the river. Flow in the aquifer adjacent to the river varies, but an equivalent water level in the aquifer is established in most locations along the river about 3 to 6 miles from the 


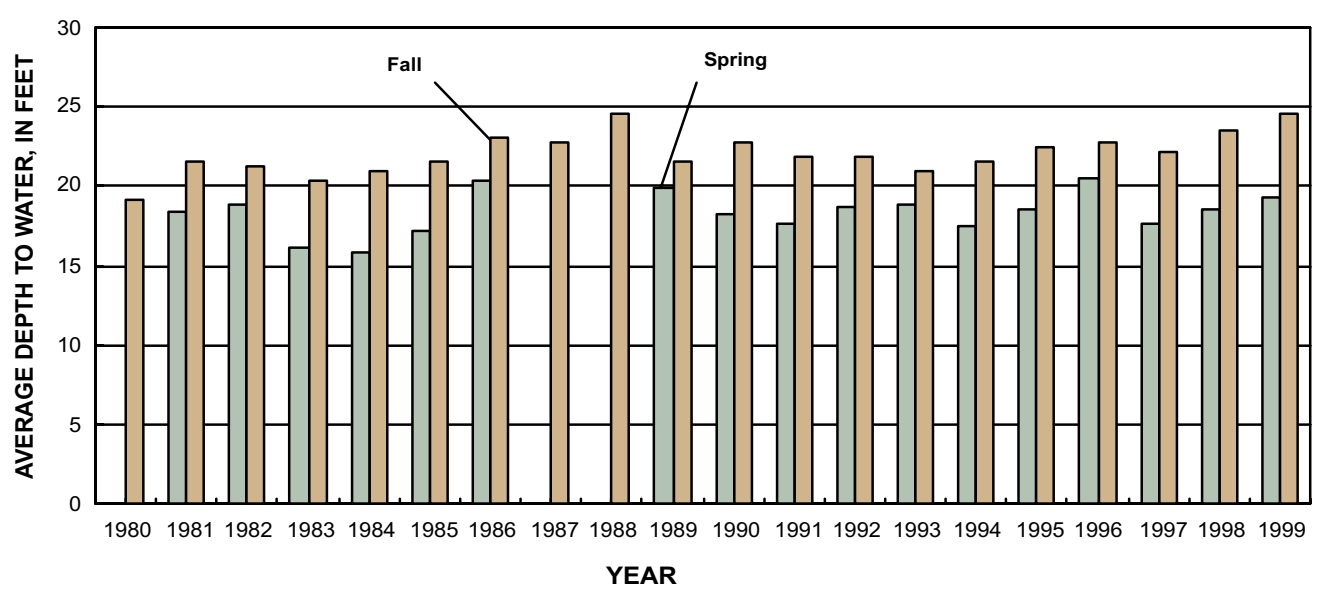

Figure 6. Average depth to water during spring and fall in the Mississipi River alluvial aquifer.

Table 2. Rainfall, in inches, during 1981-96 at Stoneville, Mississippi

\begin{tabular}{lrrrrrrrrrrrrr}
\hline & Jan & Feb & Mar & Apr & May & Jun & Jul & Aug & Sept & Oct & Nov & Dec & Total \\
\hline 1981 & 1.53 & 2.42 & 4.25 & 0.98 & 4.78 & 3.29 & 3.10 & 1.56 & 4.95 & 3.09 & 2.55 & 2.30 & 34.80 \\
1982 & 3.74 & 4.66 & 1.69 & 7.57 & 1.75 & 4.84 & 2.42 & 1.52 & 2.83 & 6.56 & 6.82 & 19.53 & 63.93 \\
1983 & 2.45 & 6.67 & 4.27 & 5.37 & 9.97 & 7.10 & 0.47 & 2.50 & 2.97 & 0.65 & 6.61 & 10.70 & 59.73 \\
1984 & 2.81 & 6.09 & 5.61 & 5.53 & 5.00 & 2.22 & 2.43 & 1.43 & 0.91 & 10.99 & 5.58 & 1.07 & 49.72 \\
1985 & 4.01 & 5.61 & 3.50 & 2.45 & 1.16 & 4.61 & 1.57 & 4.38 & 3.28 & 6.26 & 2.58 & 4.29 & 43.70 \\
1986 & 0.74 & 1.72 & 1.97 & 1.92 & 5.47 & 3.45 & 2.06 & 0.91 & 0.72 & 5.03 & 12.98 & 4.22 & 41.19 \\
1987 & 3.06 & 8.23 & 5.03 & 1.99 & 7.55 & 4.58 & 3.74 & 1.76 & 1.47 & 0.27 & 10.95 & 4.99 & 53.62 \\
1988 & 2.40 & 2.00 & 7.80 & 2.10 & 0.70 & 0.57 & 3.40 & 1.70 & 6.50 & 4.40 & 4.50 & 4.70 & 40.77 \\
1989 & 8.24 & 5.97 & 2.84 & 4.65 & 5.96 & 9.45 & 9.12 & 3.62 & 7.00 & 0.81 & 4.37 & 5.31 & 67.34 \\
1990 & 7.66 & 6.94 & 7.71 & 3.50 & 4.44 & 3.26 & 3.28 & 0.54 & 3.18 & 4.70 & 4.31 & 9.59 & 59.11 \\
1991 & 2.42 & 11.95 & 4.51 & 16.93 & 6.35 & 2.05 & 2.92 & 1.63 & 3.39 & 3.38 & 3.67 & 7.09 & 66.29 \\
1992 & 3.70 & 5.50 & 4.54 & 1.86 & 2.43 & 5.65 & 4.06 & 4.49 & 2.96 & 0.79 & 4.68 & 3.95 & 44.61 \\
1993 & 3.55 & 2.15 & 2.85 & 6.65 & 6.59 & 3.80 & 2.91 & 3.11 & 4.34 & 2.70 & 2.67 & 3.26 & 44.58 \\
1994 & 7.48 & 5.32 & 6.01 & 3.48 & 5.12 & 1.98 & 11.58 & 0.45 & 1.14 & 7.52 & 3.16 & 4.99 & 58.23 \\
1995 & 5.26 & 5.82 & 7.27 & 9.62 & 2.62 & 4.02 & 5.82 & 1.41 & 1.60 & 1.30 & 2.62 & 6.59 & 53.95 \\
1996 & 2.65 & 0.71 & 5.41 & 5.92 & 2.45 & 3.17 & 3.32 & 4.33 & 4.39 & 2.88 & 6.11 & 6.35 & 47.69 \\
Average & 4.50 & 4.72 & 5.45 & 4.83 & 4.77 & 3.92 & 3.82 & 2.38 & 3.23 & 3.17 & 5.15 & 5.75 & 52.05 \\
$(1915-96)$ & & & & & & & & & & & & & \\
\hline
\end{tabular}




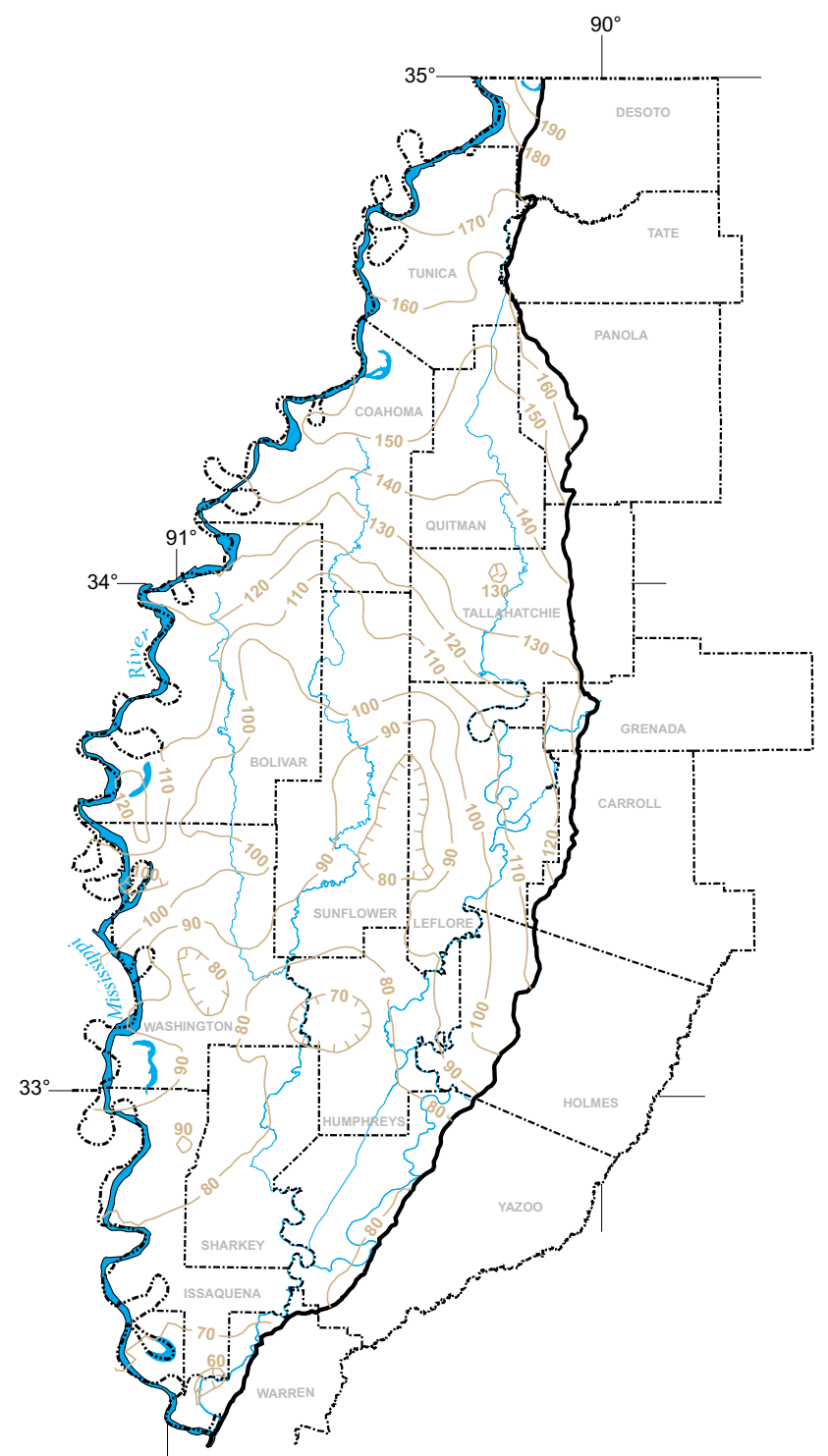

a. Lowest Potentiometric Surface (fall 1988)

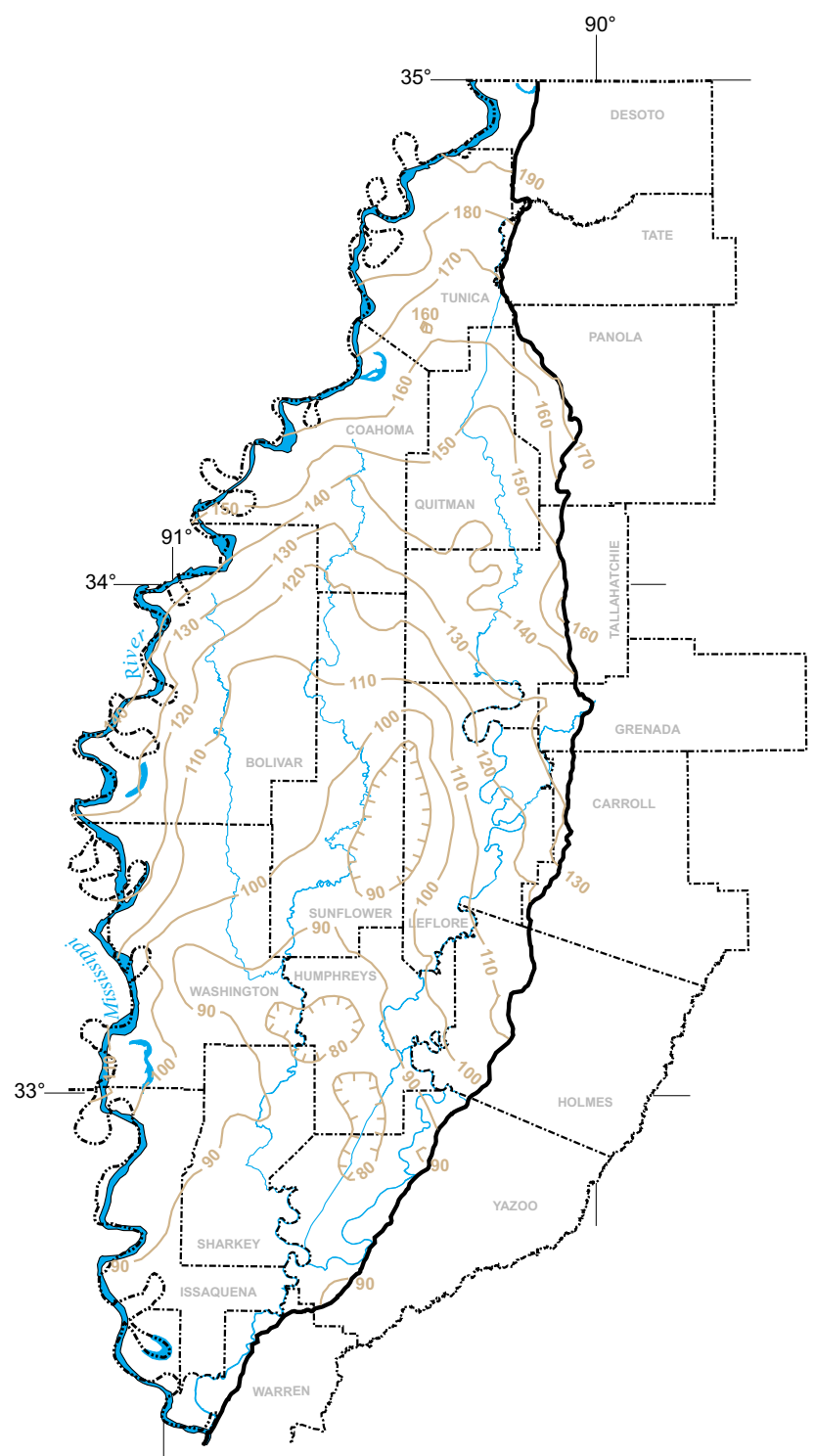

b. Highest Potentiometric Surface (spring 1984)

\section{EXPLANATION}

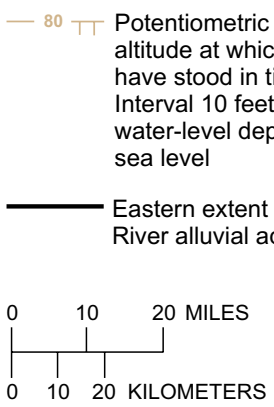

Figure 7. Lowest (a) and highest (b) potentiometric surfaces of the Mississippi River alluvial aquifer since 1980. 
river. From this hinge point in the potentiometric surface, the potentiometric surface generally slopes to the southeast toward the central part of the Delta. Natural flow from the alluvial aquifer (discharge) provides water to internal streams and lakes in the Delta when the stages of the streams and lakes are below the level of the potentiometric surface of the aquifer; conversely, during periods when internal streams have sufficient runoff to produce high stream stages, flow is reversed locally and water flows from the streams into the aquifer (fig. 8). The magnitude of the flow between the aquifer and the internal surface-water bodies is determined by the extent of incisement of the surface-water body channel into the upper confining unit (topstratum), the head difference between the aquifer and the surface water, and the duration of the head difference. Due to the shorter duration of the high stages in the unregulated internal streams and the shallower incisement of the channels into the alluvium as compared to the Mississippi River, the internal streams at high stages have less effect on the regional flow pattern in the alluvial aquifer than does the Mississippi River. On a local scale, the internal water bodies are major recharge sources in most areas in the Delta, especially surface-water bodies near the heavy withdrawal areas in the central part of the Delta.

Water that enters the aquifer areally as direct infiltration from precipitation is a small part of the total annual rainfall (reported in 1964 by Krinitzsky and Wire to be about 5 percent), but is a significant flow component in the alluvial aquifer flow system.

Recharge from precipitation can vary substantially on a local basis due to variations in permeability of the topstratum, but on a regional basis areal recharge is believed to be relatively uniform and, as a result, has little effect on regional flow direction. Water that enters the alluvial aquifer from underlying waterbearing units (Cockfield Formation and Sparta Sand), or water that flows from the alluvial aquifer into these units may locally have some impact on flow direction and shape of the potentiometric surface in areas where the alluvial aquifer is hydraulically connected to the underlying water-bearing units.

\section{Water Volume}

The sand and gravel deposits in the Mississippi River alluvium, which compose the alluvial aquifer, have the capacity to store an enormous volume of water. Assuming the alluvial aquifer has an average specific yield of 0.32 , and ignoring the water stored as the result of compaction of water and the expansion of the aquifer with increasing head, the aquifer in the Delta has the capacity to store an average of about 21,570 acre-feet of water per square mile (fig. 9). Based on twice yearly water-level measurements made since fall 1980, the least volume of water stored in the alluvial aquifer was determined to have occurred during fall 1999 with an average of about 20,690 acre-feet per square mile. Generally, areas in the Delta with the greatest volume of water are those where the sand and gravel beds are thickest. Most counties in the Delta have large volumes of alluvial water, but an exception is west-central Washington County where the sand and gravel beds are less than 50 feet thick. Bolivar and Sharkey Counties have the greatest average thickness of sand and gravel in the Delta and, consequently, have the largest volume of water per square mile of surface area. The greatest average total volume of water in the aquifer since fall 1980 was calculated to be about 21,290 acre-feet per square mile during spring 1984. On a regional basis, only a small volume of water has been depleted from the alluvial aquifer. Since fall 1980 , the amount of water stored in the aquifer has ranged from about 96 to about 99 percent of the aquifer's unconfined capacity, although localized areas in the central part of the Delta have experienced drawdowns greater than 30 feet.

The volume of water in the alluvial aquifer fluctuates yearly from spring to fall depending on climatic, hydrologic, and economic conditions that influence recharge, discharge, and pumpage. The volume of water in the aquifer increases from fall to spring and generally decreases from spring to fall. The magnitude of the volume change depends upon the amount of natural discharge from and recharge to the aquifer and the magnitude of pumpage. Most of the natural discharge and pumpage from the aquifer occurs during summer and early fall, whereas most of the recharge occurs from late fall through spring. Within about 3 to 6 miles of the Mississippi River, the volume of water in the alluvial aquifer fluctuates due to the typically large seasonal stage changes in the Mississippi River. From 1988 to 1996, the average monthly stage of the Mississippi River at Vicksburg ranged from 46.3 to 91.9 feet above sea level (table 3). Based on water-level measurements made during fall and spring from 1980 to 1999 , assuming a specific yield of 0.32 , and that the 


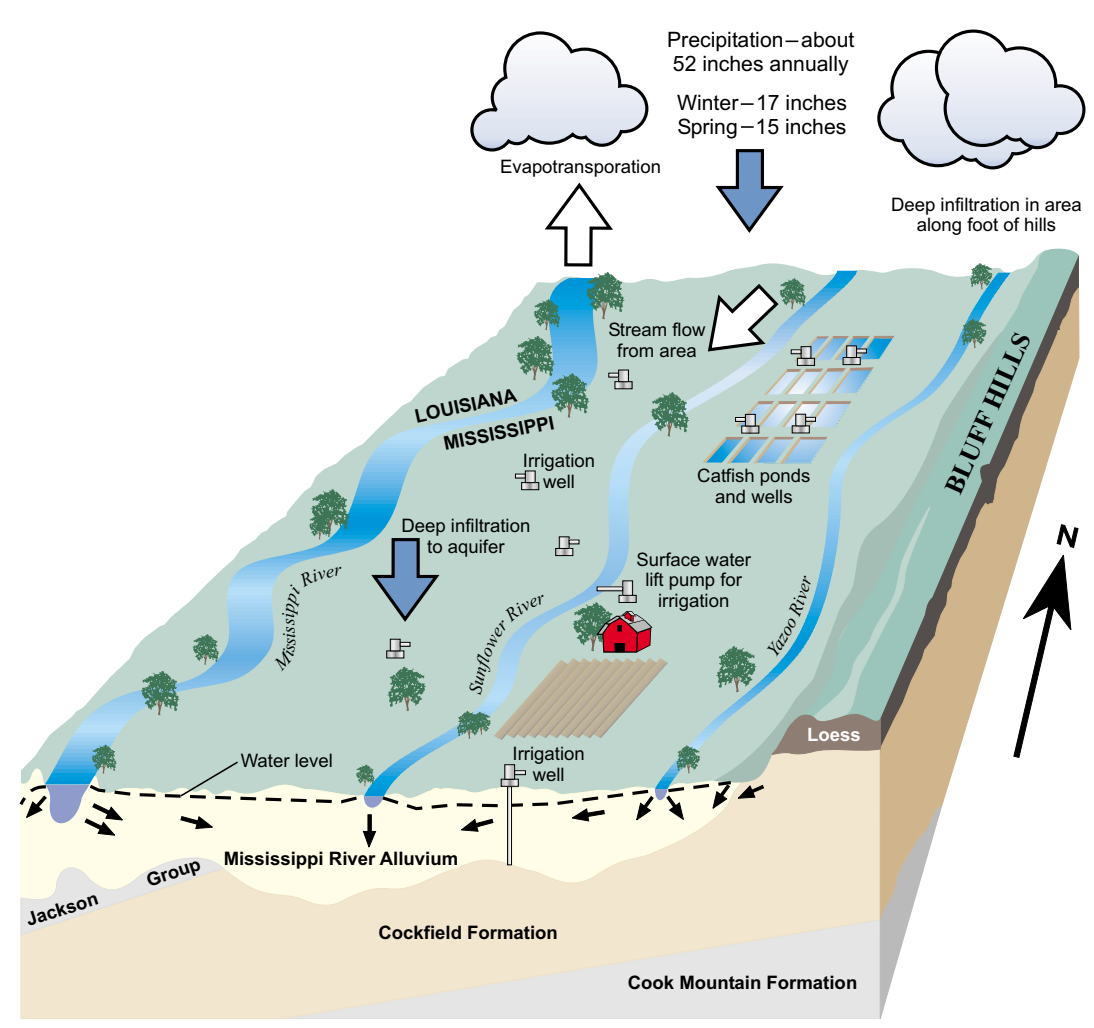

A Winter and Spring Seasons

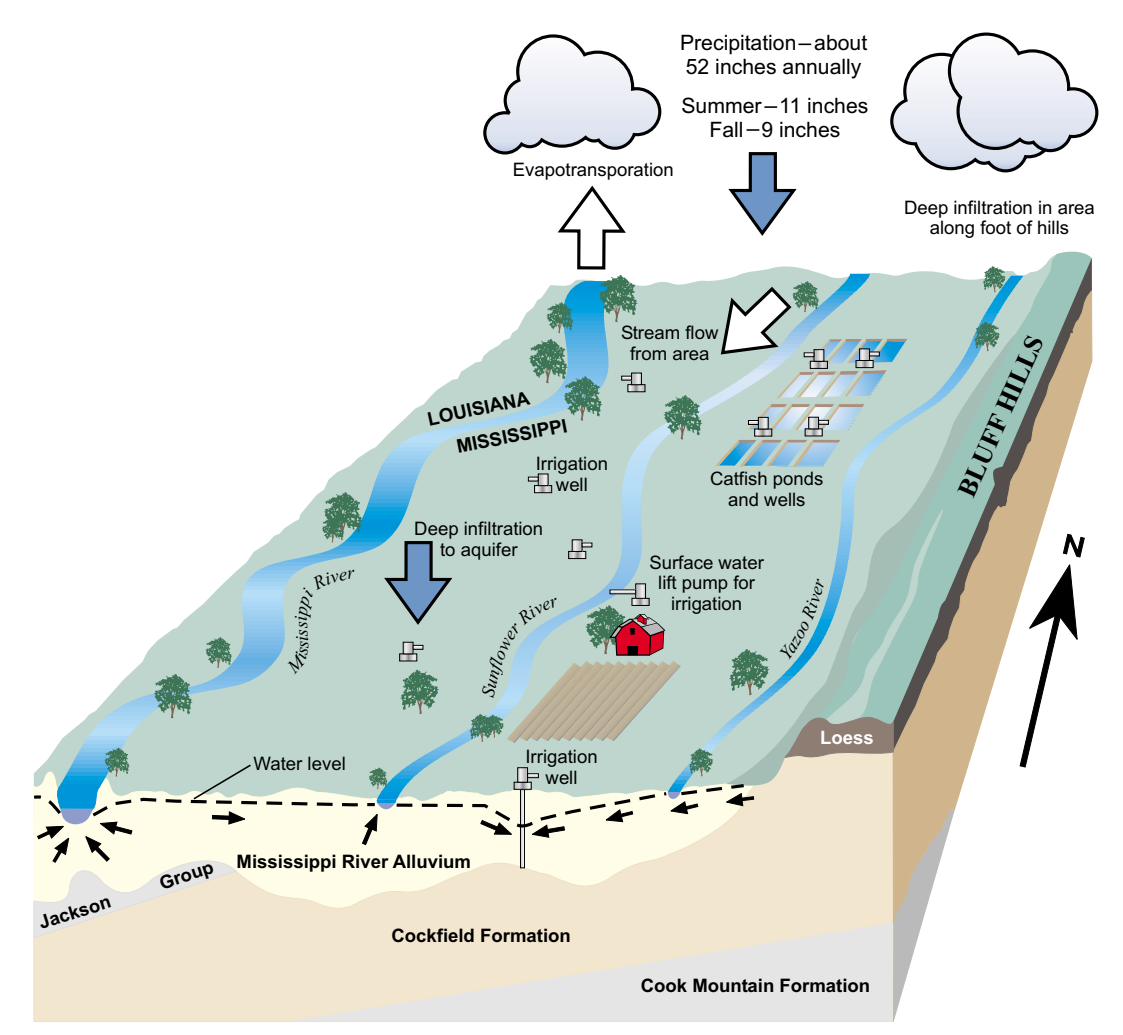

B Summer and Fall Seasons

Figure 8. Hydrologic and climatic processes in the Delta. 


\section{EXPLANATION}

Acre-feet of water per square mile in the alluvial aquifer during fall 1999

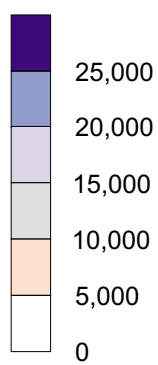

25,000
20,000
5,000
0,000
5,000

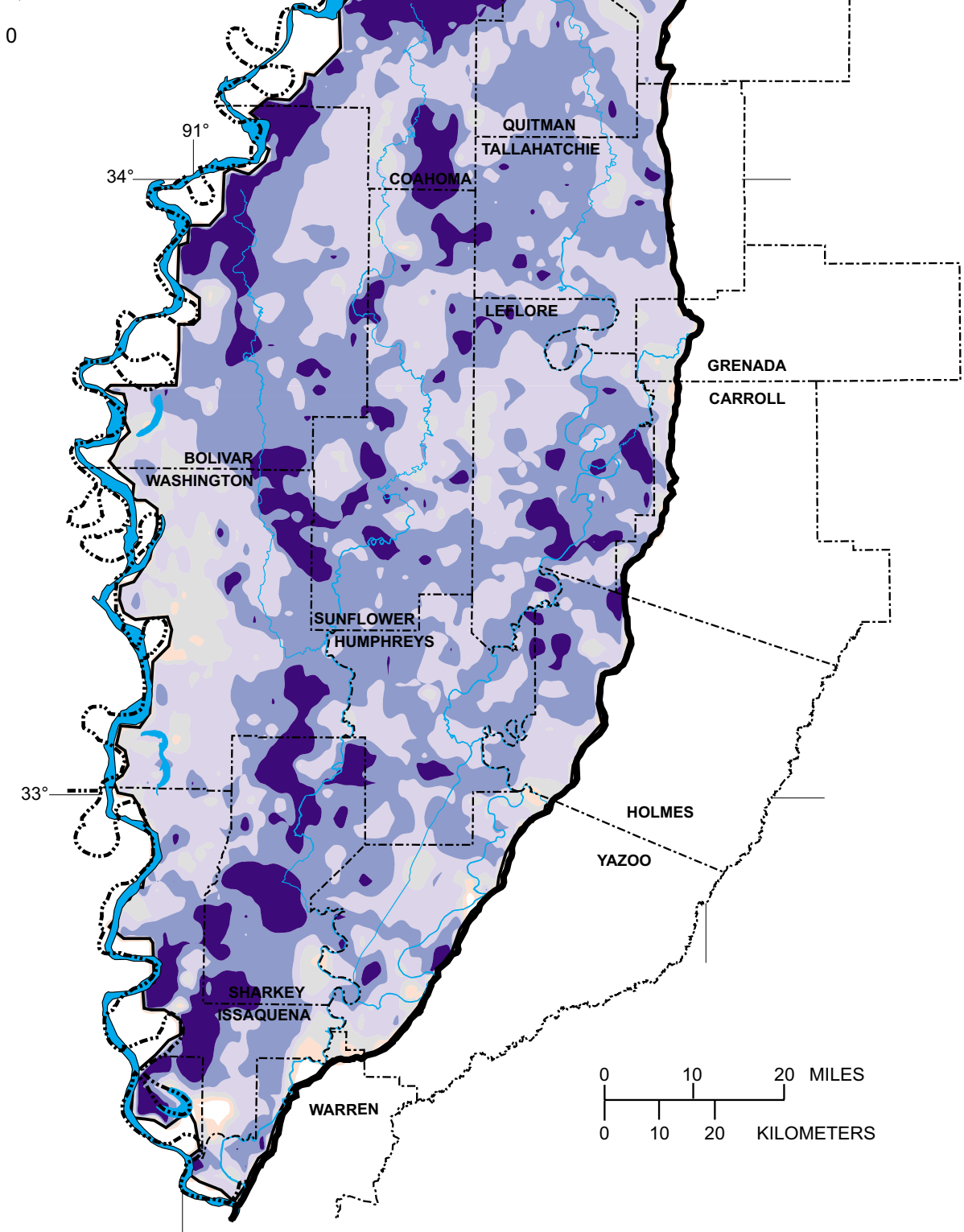

Figure 9. Volume of water in the Mississippi river alluvial aquifer during fall 1999. 
Table 3. Average monthly stage, in feet above sea level, at selected gage sites on the Mississippi River, 1988-96

\begin{tabular}{|c|c|c|c|c|c|c|c|c|}
\hline Date & & Memphis & Helena & Rosedale & $\begin{array}{c}\text { Arkansas } \\
\text { City }\end{array}$ & Greenville & $\begin{array}{l}\text { Lake } \\
\text { Providence }\end{array}$ & Vicksburg \\
\hline 1988 & $\begin{array}{l}\text { January } \\
\text { February } \\
\text { March } \\
\text { April } \\
\text { May } \\
\text { June } \\
\text { July } \\
\text { August } \\
\text { September } \\
\text { October } \\
\text { November } \\
\text { December }\end{array}$ & $\begin{array}{l}198.1 \\
199.8 \\
194.7 \\
197.4 \\
186.0 \\
177.1 \\
174.9 \\
174.9 \\
175.8 \\
176.8 \\
185.3 \\
186.1\end{array}$ & $\begin{array}{l}164.3 \\
165.2 \\
159.7 \\
162.3 \\
150.3 \\
141.3 \\
139.4 \\
139.1 \\
140.0 \\
140.8 \\
149.4 \\
151.3\end{array}$ & $\begin{array}{l}133.5 \\
132.0 \\
127.6 \\
131.3 \\
116.4 \\
105.1 \\
103.5 \\
103.0 \\
103.4 \\
104.7 \\
112.6 \\
117.1\end{array}$ & $\begin{array}{r}120.6 \\
119.0 \\
115.4 \\
118.8 \\
105.6 \\
95.8 \\
93.6 \\
93.5 \\
93.7 \\
94.7 \\
101.4 \\
105.8\end{array}$ & $\begin{array}{r}109.9 \\
108.7 \\
105.1 \\
108.6 \\
95.7 \\
86.4 \\
84.0 \\
83.7 \\
83.8 \\
84.7 \\
90.9 \\
95.9\end{array}$ & $\begin{array}{l}91.8 \\
90.4 \\
86.3 \\
89.8 \\
76.0 \\
65.3 \\
63.5 \\
63.5 \\
63.5 \\
65.2 \\
71.0 \\
76.0\end{array}$ & $\begin{array}{l}74.9 \\
75.0 \\
70.7 \\
74.0 \\
59.8 \\
49.4 \\
46.5 \\
46.5 \\
46.3 \\
48.0 \\
53.7 \\
60.5\end{array}$ \\
\hline 1989 & $\begin{array}{l}\text { January } \\
\text { February } \\
\text { March } \\
\text { April } \\
\text { May } \\
\text { June } \\
\text { July } \\
\text { August } \\
\text { September } \\
\text { October } \\
\text { November } \\
\text { December }\end{array}$ & $\begin{array}{l}202.2 \\
202.2 \\
208.8 \\
205.4 \\
198.3 \\
200.9 \\
195.7 \\
184.9 \\
192.2 \\
192.4 \\
190.2 \\
185.1\end{array}$ & $\begin{array}{l}167.7 \\
167.5 \\
175.8 \\
171.8 \\
163.2 \\
166.0 \\
161.1 \\
148.3 \\
156.1 \\
156.6 \\
153.9 \\
149.1\end{array}$ & $\begin{array}{l}132.5 \\
133.4 \\
142.7 \\
138.6 \\
129.3 \\
132.3 \\
127.4 \\
112.6 \\
120.6 \\
120.2 \\
117.2 \\
112.1\end{array}$ & $\begin{array}{l}119.1 \\
120.1 \\
128.5 \\
124.9 \\
116.1 \\
118.9 \\
115.0 \\
102.1 \\
108.8 \\
108.1 \\
105.7 \\
101.6\end{array}$ & $\begin{array}{r}108.8 \\
109.9 \\
118.7 \\
115.2 \\
106.4 \\
109.4 \\
105.8 \\
93.0 \\
99.3 \\
98.7 \\
96.2 \\
92.3\end{array}$ & $\begin{array}{r}90.4 \\
91.2 \\
101.1 \\
97.7 \\
87.4 \\
90.7 \\
87.5 \\
72.9 \\
79.3 \\
78.6 \\
75.1 \\
73.3\end{array}$ & $\begin{array}{l}75.6 \\
75.7 \\
86.1 \\
82.7 \\
72.3 \\
75.4 \\
73.5 \\
57.3 \\
63.1 \\
62.5 \\
60.3 \\
56.4\end{array}$ \\
\hline 1990 & $\begin{array}{l}\text { January } \\
\text { February } \\
\text { March } \\
\text { April } \\
\text { May } \\
\text { June } \\
\text { July } \\
\text { August } \\
\text { September } \\
\text { October } \\
\text { November } \\
\text { December }\end{array}$ & $\begin{array}{l}195.3 \\
210.8 \\
205.6 \\
197.8 \\
204.9 \\
208.4 \\
198.4 \\
191.6 \\
188.5 \\
188.8 \\
187.7 \\
199.4\end{array}$ & $\begin{array}{l}158.9 \\
176.0 \\
172.2 \\
163.4 \\
170.4 \\
174.7 \\
163.2 \\
155.7 \\
152.5 \\
152.7 \\
151.6 \\
163.4\end{array}$ & $\begin{array}{l}121.8 \\
140.6 \\
141.2 \\
134.0 \\
140.3 \\
142.2 \\
128.5 \\
120.6 \\
118.0 \\
118.1 \\
116.5 \\
126.7\end{array}$ & $\begin{array}{l}109.6 \\
126.2 \\
127.4 \\
121.2 \\
126.5 \\
128.5 \\
115.5 \\
108.2 \\
105.7 \\
105.4 \\
104.3 \\
113.3\end{array}$ & $\begin{array}{r}99.4 \\
115.9 \\
117.2 \\
111.2 \\
116.1 \\
118.5 \\
105.5 \\
98.8 \\
96.2 \\
95.9 \\
94.7 \\
103.3\end{array}$ & $\begin{array}{r}80.1 \\
98.5 \\
100.3 \\
93.5 \\
98.7 \\
101.9 \\
87.1 \\
79.4 \\
76.2 \\
75.2 \\
74.1 \\
83.2\end{array}$ & $\begin{array}{l}64.4 \\
82.9 \\
85.4 \\
79.1 \\
83.2 \\
86.7 \\
71.3 \\
62.8 \\
60.1 \\
59.0 \\
58.2 \\
67.1\end{array}$ \\
\hline 1991 & $\begin{array}{l}\text { January } \\
\text { February } \\
\text { March } \\
\text { April } \\
\text { May } \\
\text { June } \\
\text { July } \\
\text { August } \\
\text { September } \\
\text { October } \\
\text { November } \\
\text { December }\end{array}$ & $\begin{array}{l}216.3 \\
204.7 \\
208.3 \\
210.1 \\
204.1 \\
198.4 \\
189.7 \\
183.4 \\
181.1 \\
180.0 \\
185.4 \\
201.7\end{array}$ & $\begin{array}{l}182.7 \\
170.2 \\
173.9 \\
176.6 \\
170.2 \\
163.5 \\
153.3 \\
145.9 \\
143.1 \\
141.9 \\
148.5 \\
166.8\end{array}$ & $\begin{array}{l}147.6 \\
136.1 \\
138.5 \\
142.5 \\
138.3 \\
129.2 \\
118.3 \\
110.7 \\
108.4 \\
106.8 \\
116.4 \\
133.6\end{array}$ & $\begin{array}{l}144.0 \\
133.7 \\
136.1 \\
139.7 \\
136.9 \\
128.6 \\
119.2 \\
112.0 \\
109.8 \\
108.7 \\
117.7 \\
131.8\end{array}$ & $\begin{array}{r}122.2 \\
112.2 \\
114.3 \\
117.9 \\
115.1 \\
106.8 \\
97.4 \\
90.2 \\
88.0 \\
86.9 \\
95.9 \\
110.0\end{array}$ & $\begin{array}{r}105.3 \\
94.5 \\
97.1 \\
100.9 \\
98.8 \\
88.7 \\
77.9 \\
69.9 \\
67.7 \\
66.7 \\
75.0 \\
92.0\end{array}$ & $\begin{array}{l}89.5 \\
80.0 \\
82.6 \\
85.7 \\
85.2 \\
74.3 \\
62.1 \\
54.7 \\
52.5 \\
51.0 \\
59.3 \\
76.7\end{array}$ \\
\hline 1992 & $\begin{array}{l}\text { January } \\
\text { February } \\
\text { March } \\
\text { April } \\
\text { May } \\
\text { June }\end{array}$ & $\begin{array}{l}194.7 \\
189.7 \\
201.8 \\
197.8 \\
193.8 \\
189.4\end{array}$ & $\begin{array}{l}159.3 \\
153.4 \\
166.8 \\
162.5 \\
158.6 \\
153.5\end{array}$ & $\begin{array}{l}126.6 \\
118.5 \\
131.5 \\
127.7 \\
124.6 \\
121.1\end{array}$ & $\begin{array}{l}113.4 \\
106.6 \\
117.9 \\
114.4 \\
111.8 \\
109.3\end{array}$ & $\begin{array}{r}103.5 \\
96.5 \\
107.6 \\
104.4 \\
102.0 \\
99.4\end{array}$ & $\begin{array}{l}84.9 \\
76.8 \\
89.2 \\
85.9 \\
83.2 \\
80.1\end{array}$ & $\begin{array}{l}70.0 \\
61.3 \\
73.6 \\
69.5 \\
67.3 \\
63.8\end{array}$ \\
\hline
\end{tabular}


Table 3. Average monthly stage, in feet above sea level, at selected gage sites on the Mississippi River, 1988-96--Continued

\begin{tabular}{|c|c|c|c|c|c|c|c|c|}
\hline Date & & Memphis & Helena & Rosedale & $\begin{array}{c}\text { Arkansas } \\
\text { City }\end{array}$ & Greenville & $\begin{array}{l}\text { Lake } \\
\text { Providence }\end{array}$ & Vicksburg \\
\hline 1992 & $\begin{array}{l}\text { July } \\
\text { August } \\
\text { September } \\
\text { October } \\
\text { November } \\
\text { December }\end{array}$ & $\begin{array}{l}191.9 \\
194.1 \\
188.1 \\
186.1 \\
193.9 \\
201.8\end{array}$ & $\begin{array}{l}155.8 \\
159.0 \\
151.6 \\
150.1 \\
157.4 \\
167.2\end{array}$ & $\begin{array}{l}122.0 \\
125.4 \\
116.3 \\
115.0 \\
121.4 \\
134.2\end{array}$ & $\begin{array}{l}109.6 \\
112.9 \\
104.8 \\
103.0 \\
108.8 \\
120.8\end{array}$ & $\begin{array}{r}99.8 \\
103.1 \\
94.7 \\
92.8 \\
98.1 \\
110.2\end{array}$ & $\begin{array}{l}80.5 \\
84.5 \\
75.1 \\
73.2 \\
78.5 \\
92.4\end{array}$ & $\begin{array}{l}63.9 \\
68.5 \\
58.6 \\
57.2 \\
62.0 \\
76.6\end{array}$ \\
\hline 1993 & $\begin{array}{l}\text { January } \\
\text { February } \\
\text { March } \\
\text { April } \\
\text { May } \\
\text { June } \\
\text { July } \\
\text { August } \\
\text { September } \\
\text { October } \\
\text { November } \\
\text { December }\end{array}$ & $\begin{array}{l}206.2 \\
198.9 \\
208.7 \\
214.7 \\
209.8 \\
200.9 \\
208.4 \\
211.1 \\
202.3 \\
201.6 \\
199.7 \\
203.4\end{array}$ & $\begin{array}{l}172.0 \\
164.1 \\
174.1 \\
181.0 \\
176.6 \\
165.7 \\
173.2 \\
177.0 \\
166.6 \\
166.4 \\
163.8 \\
169.2\end{array}$ & $\begin{array}{l}139.3 \\
132.0 \\
139.8 \\
147.2 \\
145.9 \\
134.1 \\
138.0 \\
141.9 \\
131.4 \\
132.1 \\
128.5 \\
135.7\end{array}$ & $\begin{array}{l}125.1 \\
118.8 \\
125.4 \\
131.6 \\
131.7 \\
121.6 \\
124.2 \\
128.0 \\
118.5 \\
119.3 \\
115.6 \\
122.1\end{array}$ & $\begin{array}{l}114.9 \\
108.6 \\
115.1 \\
121.2 \\
121.8 \\
111.7 \\
114.1 \\
118.1 \\
108.7 \\
109.4 \\
105.4 \\
112.1\end{array}$ & $\begin{array}{r}97.5 \\
91.6 \\
97.6 \\
104.1 \\
105.0 \\
94.2 \\
95.9 \\
100.9 \\
90.3 \\
91.2 \\
86.2 \\
94.4\end{array}$ & $\begin{array}{l}82.2 \\
75.7 \\
81.8 \\
88.3 \\
89.5 \\
78.8 \\
79.6 \\
84.8 \\
74.2 \\
75.2 \\
69.9 \\
79.2\end{array}$ \\
\hline 1994 & $\begin{array}{l}\text { January } \\
\text { February } \\
\text { March } \\
\text { April } \\
\text { May } \\
\text { June } \\
\text { July } \\
\text { August } \\
\text { September } \\
\text { October } \\
\text { November } \\
\text { December }\end{array}$ & $\begin{array}{l}197.2 \\
210.7 \\
213.7 \\
217.1 \\
208.6 \\
193.1 \\
192.9 \\
189.0 \\
184.1 \\
184.9 \\
188.2 \\
195.3\end{array}$ & $\begin{array}{l}161.3 \\
176.4 \\
180.4 \\
183.2 \\
175.7 \\
157.4 \\
157.3 \\
152.7 \\
147.4 \\
147.9 \\
151.5 \\
160.1\end{array}$ & $\begin{array}{l}127.3 \\
141.1 \\
146.6 \\
148.3 \\
145.2 \\
123.3 \\
122.8 \\
117.4 \\
111.9 \\
111.7 \\
118.5 \\
126.8\end{array}$ & $\begin{array}{l}114.2 \\
126.2 \\
131.4 \\
132.9 \\
130.6 \\
110.9 \\
110.5 \\
106.0 \\
101.7 \\
101.3 \\
107.7 \\
114.6\end{array}$ & $\begin{array}{r}103.9 \\
115.8 \\
121.0 \\
122.5 \\
120.4 \\
100.8 \\
100.4 \\
95.8 \\
91.2 \\
90.6 \\
97.3 \\
104.1\end{array}$ & $\begin{array}{r}85.1 \\
98.4 \\
104.1 \\
105.1 \\
103.3 \\
82.8 \\
82.2 \\
77.5 \\
72.3 \\
71.3 \\
78.6 \\
85.7\end{array}$ & $\begin{array}{l}69.7 \\
83.5 \\
88.9 \\
89.6 \\
89.0 \\
66.6 \\
66.2 \\
61.1 \\
56.9 \\
55.9 \\
61.9 \\
70.0\end{array}$ \\
\hline 1995 & $\begin{array}{l}\text { January } \\
\text { February } \\
\text { March } \\
\text { April } \\
\text { May } \\
\text { June } \\
\text { July } \\
\text { August } \\
\text { September } \\
\text { October } \\
\text { November } \\
\text { December }\end{array}$ & $\begin{array}{l}195.1 \\
197.4 \\
200.7 \\
195.2 \\
209.5 \\
212.9 \\
195.9 \\
192.8 \\
184.2 \\
186.1 \\
192.7 \\
189.2\end{array}$ & $\begin{array}{l}159.4 \\
162.1 \\
165.7 \\
159.3 \\
174.5 \\
180.2 \\
161.2 \\
157.5 \\
148.3 \\
149.8 \\
156.8 \\
153.2\end{array}$ & $\begin{array}{l}125.1 \\
127.6 \\
131.8 \\
125.4 \\
140.3 \\
149.0 \\
129.6 \\
124.0 \\
114.0 \\
113.6 \\
119.9 \\
117.0\end{array}$ & $\begin{array}{l}112.6 \\
114.9 \\
118.9 \\
113.0 \\
126.5 \\
135.1 \\
117.5 \\
111.6 \\
102.2 \\
102.6 \\
107.8 \\
105.4\end{array}$ & $\begin{array}{r}102.1 \\
104.5 \\
108.5 \\
102.7 \\
115.8 \\
124.5 \\
107.5 \\
101.5 \\
91.9 \\
92.2 \\
97.3 \\
94.8\end{array}$ & $\begin{array}{r}83.5 \\
86.4 \\
91.3 \\
84.7 \\
98.5 \\
107.8 \\
90.3 \\
83.4 \\
73.3 \\
73.7 \\
78.3 \\
76.4\end{array}$ & $\begin{array}{l}67.9 \\
71.4 \\
76.4 \\
69.2 \\
82.8 \\
91.9 \\
75.3 \\
67.4 \\
58.0 \\
57.5 \\
62.3 \\
60.5\end{array}$ \\
\hline 1996 & $\begin{array}{l}\text { January } \\
\text { February } \\
\text { March } \\
\text { April } \\
\text { May } \\
\text { June } \\
\text { July } \\
\text { August } \\
\text { September } \\
\text { October } \\
\text { November } \\
\text { December }\end{array}$ & \begin{tabular}{l|}
193.7 \\
201.3 \\
200.8 \\
201.0 \\
212.0 \\
208.7 \\
195.3 \\
192.6 \\
187.0 \\
188.9 \\
200.2 \\
207.6
\end{tabular} & $\begin{array}{l}157.9 \\
166.3 \\
165.8 \\
166.0 \\
178.3 \\
175.5 \\
160.1 \\
156.7 \\
151.2 \\
152.9 \\
164.2 \\
172.9\end{array}$ & $\begin{array}{l}122.7 \\
130.6 \\
130.1 \\
130.3 \\
144.5 \\
144.8 \\
125.4 \\
121.6 \\
115.0 \\
117.8 \\
127.6 \\
137.5\end{array}$ & $\begin{array}{l}110.2 \\
117.5 \\
116.5 \\
117.1 \\
129.9 \\
130.9 \\
112.8 \\
109.5 \\
103.4 \\
106.2 \\
115.3 \\
123.9\end{array}$ & $\begin{array}{r}99.5 \\
106.8 \\
105.7 \\
106.6 \\
119.0 \\
120.5 \\
103.0 \\
99.7 \\
93.1 \\
95.6 \\
104.7 \\
113.3\end{array}$ & $\begin{array}{r}80.8 \\
89.1 \\
87.6 \\
89.0 \\
101.7 \\
104.1 \\
85.9 \\
81.7 \\
74.9 \\
77.7 \\
86.6 \\
96.1\end{array}$ & $\begin{array}{l}65.0 \\
73.4 \\
71.4 \\
73.1 \\
84.9 \\
87.9 \\
69.2 \\
65.6 \\
58.0 \\
61.1 \\
70.1 \\
80.4\end{array}$ \\
\hline
\end{tabular}


aquifer is under unconfined conditions, the estimated average rate of gain of water to the alluvial aquifer from fall to spring is about 1,500 million gallons per day (201 million cubic feet per day). The least gain of water from fall to spring since fall 1980 was about 380 million gallons per day (51 million cubic feet per day) from fall 1985 to spring 1986 (fig. 10). From November 1985 through April 1986, only 13.22 inches of precipitation was recorded at Stoneville, as compared to the long-term average of 30.40 inches for the same 6-month period (table 2). The average rainfall at Stoneville for this period since 1981 is 29.41 inches. The greatest gain of water from fall to spring since 1981 was about 2,200 million gallons per day (294 million cubic feet per day) from fall 1988 to spring 1989. This recovery occurred after the severe drought in summer 1988. The volume of water in the alluvial aquifer has decreased from spring to fall every year since 1980 except during 1989, when 35.96 inches of rainfall was recorded at Stoneville from May through October. The long-term average rainfall for this 6-month period at Stoneville is 21.29 inches. Including the gain in water from spring to fall 1989, the estimated average loss of water from the alluvial aquifer from spring to fall since 1980 is about 1,800 million gallons per day (241 million cubic feet per day). The greatest loss of water from the aquifer from spring to fall since 1980 was about 3,200 million gallons per day (428 million cubic feet per day) in 1999.

\section{Water Quality}

The quality of water in the alluvial aquifer in the Mississippi Delta is generally well suited for irrigation, but less suited for municipal use and some industrial uses. Most of the industrial use is for cooling water since the supply is plentiful and the water temperature is stable at about the average annual air temperature (62 to 66 degrees Fahrenheit). The water is commonly a hard, calcium bicarbonate type, and usually contains appreciable amounts of manganese. Dissolved iron concentrations are usually greater than 3.0 milligrams per liter making the water less desirable for municipal use. Dissolved solids concentrations in 68 water samples from the aquifer ranged from 153 to 751 milligrams per liter (Dalsin, 1978). Along the eastern edge of the alluvial plain adjacent to the Bluff Hills, the quality of alluvial water is better suited for personal use than water from other areas of the Delta. The relation between dissolved solids concentration and specific conductance is shown in figure 11 .

Specific conductance measurements were made during August 1992 and August 1998 on water samples collected from about 300 irrigation wells pumping from the alluvial aquifer in the Mississippi Delta. The specific conductance studies were made to determine an estimate of the areal distribution of dissolved solids in the aquifer, and to help determine the sources and relative magnitudes of recharge to the aquifer. The results of the 1992 and 1998 specific conductance studies indicate that the specific conductance of the alluvial aquifer water increases from east to west with the largest values between 1,400 and 1,600 microsiemens per centimeter occurring in west-central and south-central Washington County (fig. 12). In parts of this area, the alluvial aquifer water may have dissolved solids concentrations greater than the desired level for some crops. The smallest values measured were between 200 and 400 microsiemens per centimeter; these were mostly in areas adjacent to the Bluff Hills along the eastern edge of the Delta. All irrigation wells sampled were outside the Mississippi River levee system, so no information is available directly adjacent to the river; however, within about 2 miles of the river, most measured water samples had a specific conductance value ranging between 600 and 800 microsiemens per centimeter. Throughout most of the Delta, the specific conductance of water from the alluvial aquifer ranged between 400 and 800 microsiemens per centimeter.

Water in streams at high stages in the Delta and in streams flowing into the Delta from the Bluff Hills naturally contains low concentrations of dissolved solids (specific conductance less than 200 microsiemens per centimeter). Water in the Mississippi River at high stages typically has a specific conductance of less than 300 microsiemens per centimeter. Most water samples collected from the Sparta and Cockfield aquifers near the edge of the Bluff Hills have specific conductance values of less than 300 microsiemens per centimeter. In the southwestern part of the Delta, the dissolved solids concentrations in the Cockfield and Sparta aquifers are greater, and specific conductance values as much as 3,000 microsiemens per centimeter were reported (Taylor and Thomson, 1971) in Washington County in water samples from wells screened in the Cockfield aquifer.

Prior to extensive development of the Sparta and Cockfield aquifers in the Mississippi embayment, the Mississippi River alluvial plain was a regional, down- 
Rate of water gain from fall to spring

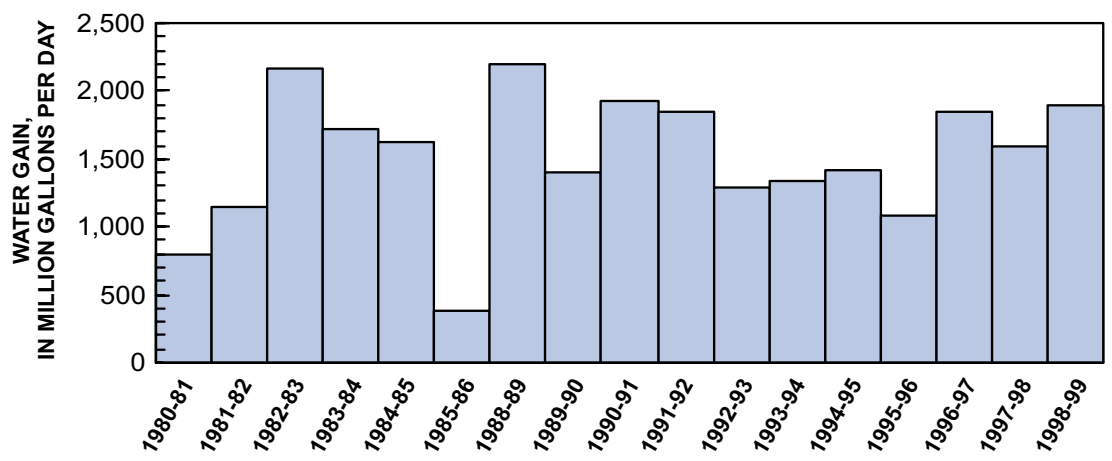

Rate of water loss from spring to fall

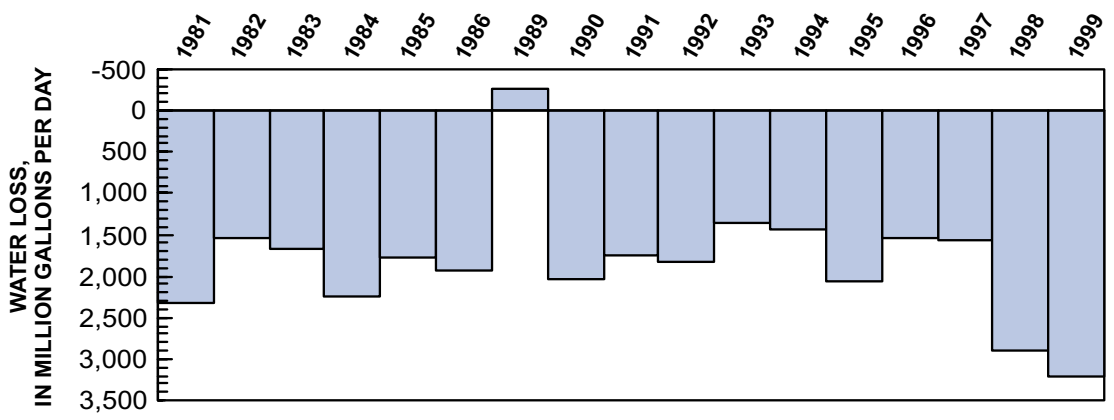

Figure 10. Estimated rate of gain and loss of water from the Mississippi River alluvial aquifer based on changes in potentiometric surfaces [No data available for 1986-87 and 1987-88].

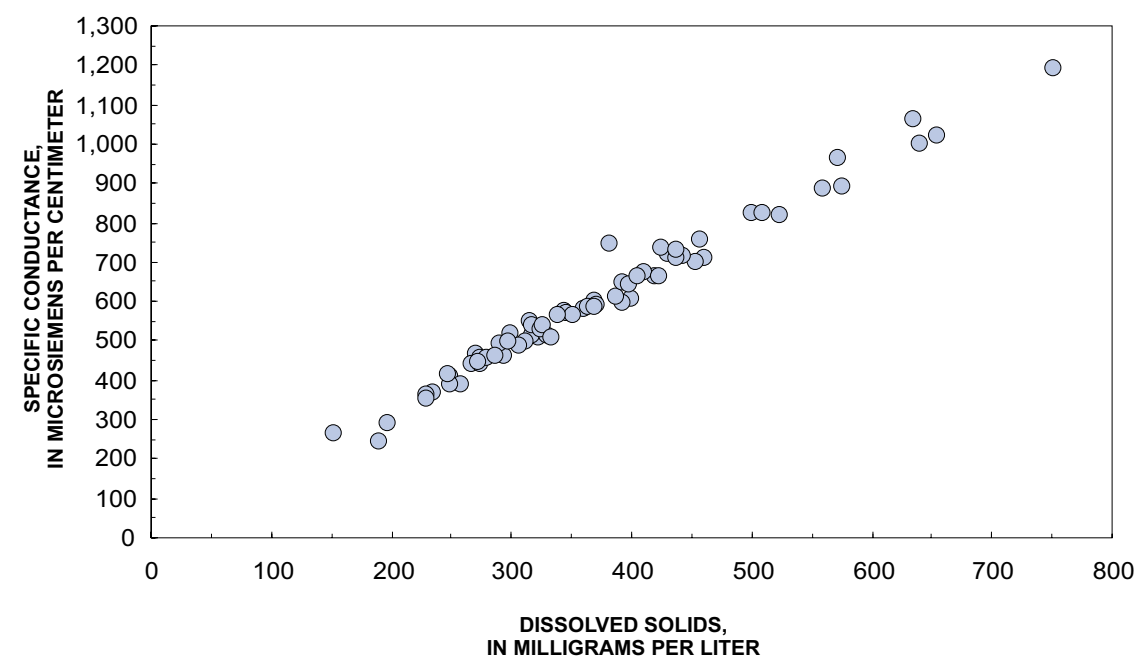

Figure 11. Relation of specific conductance to dissolved solids in the Mississippi River alluvial aquifer. 


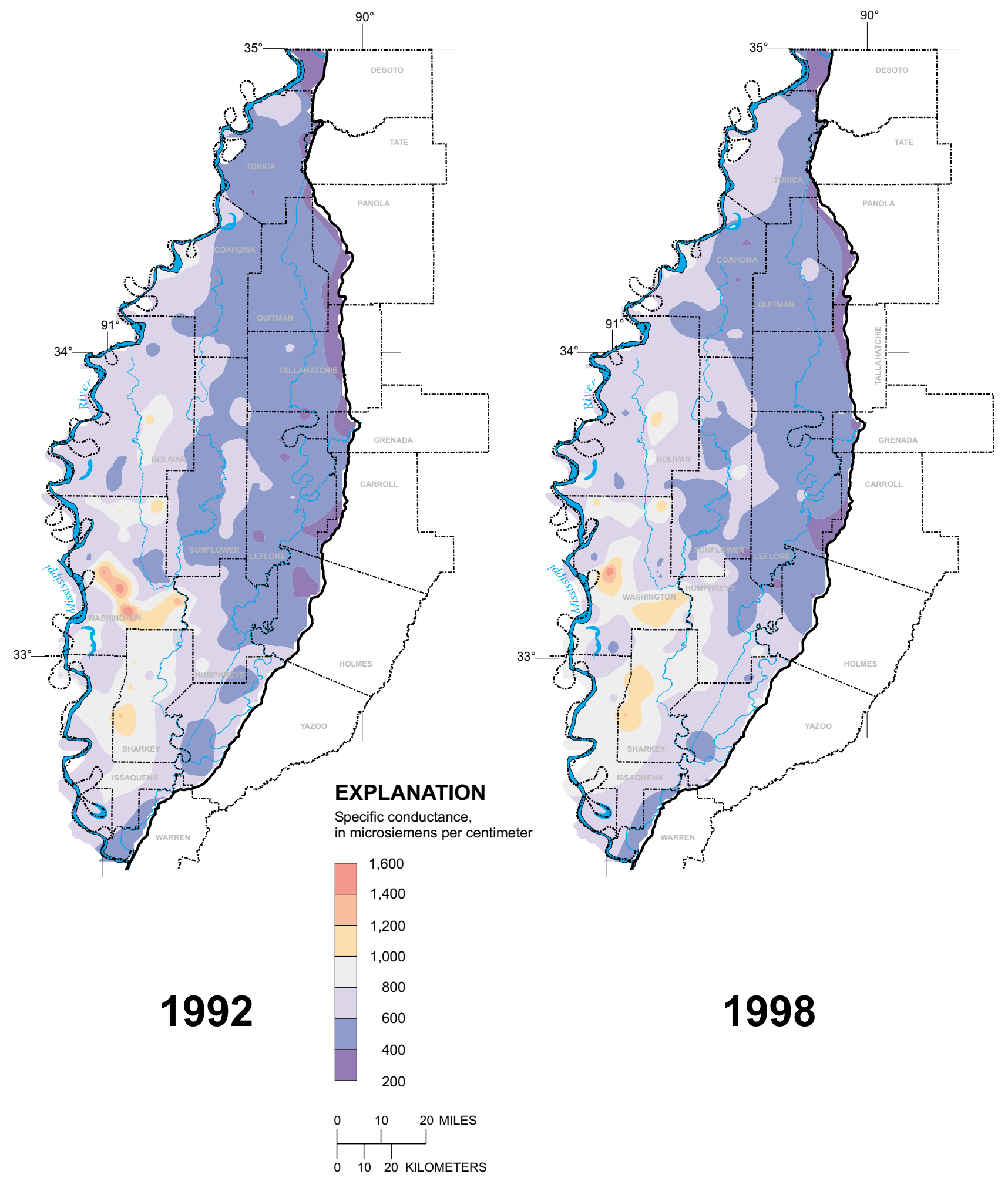

Figure 12. Specific conductance of water in the Mississippi River alluvial aquifer in 1992 and 1998. 
dip discharge area for these two aquifers. In the Delta, the predevelopment potentiometric surfaces of the underlying Sparta and Cockfield aquifers were substantially higher than the potentiometric surface of the alluvial aquifer. In areas where the underlying aquifers were in contact with the alluvial aquifer, water flowed upward from the Sparta and Cockfield aquifers into the alluvial aquifer. As pumpage increased in the Sparta and Cockfield aquifers, the potentiometric surfaces of the two aquifers declined, and the rate of discharge into the alluvial aquifer decreased to the point where the net regional discharge to the alluvial aquifer in the Mississippi Delta probably is very small. Greater specific conductance measured in water in the alluvial aquifer in the west-central part of the Delta may be the result of upward movement of water from the Cockfield aquifer during predevelopment time. It is also possible that the higher specific conductance water was more extensive in the alluvial aquifer during predevelopment time than during the 1992 and 1998 study periods. The average specific conductance of water in this area of the alluvial aquifer may be decreasing as a result of decreasing recharge from the underlying aquifers and increasing recharge of lower specific conductance water to the alluvial aquifer. The two maps shown in figure 12 represent only snapshots in time, but indicate that the average specific conductance of alluvial water in

Washington County may be decreasing. Additional specific conductance studies are needed to verify this interpretation.

The influence of Mississippi River water on the specific conductance of the water in the alluvial aquifer outside the levee system seems to be small; directly adjacent to the river, water in the aquifer is probably more reflective of the quality of the water in the river at high stage. The results of the specific conductance studies give support to the assumption that long-term net recharge from the Mississippi River to the alluvial aquifer is probably small (Boswell and others, 1968); however, the possibility exists that water from the Mississippi River is influenced by geochemical processes as the water moves through the aquifer resulting in increased dissolved solids concentrations.

The areal distribution of specific conductance indicates that the water with a low concentration of dissolved solids that flows into the alluvial aquifer along the eastern edge of the alluvial plain has a substantial influence on the quality of water in the aquifer. The areal distribution of specific conductance also indicates that recharge at the eastern edge of the Delta is a major source of water for the alluvial aquifer (fig. 12). Recharge near the eastern edge of the Delta consists of infiltration from precipitation, flow from the YazooYalobusha-Tallahatchie-Yocona-Coldwater River drainage system, runoff from the Bluff Hills area, seepage from water-bearing units underlying the loesscapped Bluff Hills onto the surface of the alluvial plain and laterally into the alluvial aquifer, and upward flow from the two underlying aquifers, predominately from the Sparta aquifer.

\section{Pumpage}

Pumpage from the alluvial aquifer for irrigation began on a small scale in the Delta in about 1910 when a few large-capacity wells were installed to provide water for rice production. Interest in rice production soon declined because of an unfavorable market, and from 1912 until 1948 few irrigation wells were drilled in the Delta. In 1950, a favorable rice market returned, and rice acreage increased substantially with most of the acreage located adjacent to streams and lakes to facilitate surface-water usage. The drought during 1951-54 reduced surface-water availability and forced many rice growers to drill wells to save their crops. From 1950 to 1954, the number of largecapacity alluvial wells in the Delta increased from 35 to 480 (Harvey, 1956). Few new large-capacity wells were installed in the aquifer from 1954 until the early 1970 's when rice and catfish production increased substantially. Presently (2000) more than 12,000 largecapacity alluvial wells are permitted in the Mississippi Delta (J.H. Hoffmann, OLWR, oral commun., 1999).

More than 98 percent of the pumpage from the alluvial aquifer is for agriculture and is concentrated in the central part of the Delta. Most of the water used for agriculture is for rice and catfish production. Prior to 1948, fewer than 5,000 acres of rice were planted annually in the Delta. By 1954, rice acreage had increased to 79,000 acres and pumpage from the alluvial aquifer that year was estimated by Harvey (1956) to be 334,000 acre-feet (298 million gallons per day). Rice acreage remained steady at about 55,000 acres until 1973. Since 1973, rice acreage has increased and fluctuated widely with the maximum annual acreage planted being greater than 300,000 acres. Catfish pond acreage has increased from about 18,000 acres in 1977 to more than 100,000 acres in 1998. In 1983, pumpage from the alluvial aquifer was estimated to be 1,100 million gallons per day (Sumner and Wasson, 1990). 
Water application rates for rice and for maintaining water levels in catfish ponds can vary widely, depending mainly on rainfall amounts during the rice growing season and water management of the catfish ponds. Sumner and Wasson (1990) reported water application rates between 3.3 and 4.2 feet per year for rice and 5.1 and 7.3 feet per year for catfish production. Currently, application rates for rice and catfish production are probably lower than the rates reported by Sumner and Wasson (1990) because Delta farmers have made a concerted effort to incorporate the most up-to-date farm research and technology to conserve water.

A major need in the Delta is to establish a Deltawide program to accurately estimate ground-water pumpage at permitted wells completed in the alluvial aquifer. In addition to estimating withdrawals at individual large-capacity wells, an understanding of the actual net removal of water from the aquifer is necessary to determine the true stress on the aquifer system. Prior studies, such as the Mississippi Delta Management Systems Evaluation Areas (MSEA) project, have quantified irrigation runoff from various farm management practices. Some of the excess irrigation runoff water likely is returned to the alluvial aquifer as it flows through small channels toward larger surface-water bodies. As a result, the current estimated pumpage at individual irrigation wells may be an overestimate of the net removal of water from the alluvial aquifer. A report by Heimes and others (1987) indicated that from 28 to 76 percent of the irrigation pumpage from the High Plains aquifer in three counties in Nebraska was resupplied to the aquifer. Although the soil characteristics in Nebraska are different from characteristics of Delta soils, the possibility of water from agricultural pumpage being resupplied to the alluvial aquifer needs to be considered.

\section{DESCRIPTION OF GROUND-WATER FLOW MODEL}

The modular three-dimensional finite-difference ground-water flow model (MODFLOW) developed by the U.S. Geological Survey (McDonald and Harbaugh, 1988) was used to simulate flow in the alluvial aquifer in the Mississippi Delta. MODFLOW is the most widely used model code in the world for simulating ground-water flow (Leake, 1997). The modular design of the computer code for individual flow packages facilitates the use and application of the model for a variety of real-world conditions. The model code uses a finite-difference method to numerically solve partial differential equations that describe ground-water flow. The model-generated solutions to differential equations provide simulated heads (water levels) and flow budgets for aquifers for specified boundary conditions, hydraulic characteristics, and aquifer stresses. The following MODFLOW packages were use to construct the model of the Mississippi River alluvial aquifer:

- BAS - Basic

- BCF - Block-Center Flow

- $\mathrm{RCH}$ - Recharge

- RIV - River

- WEL - Well

- GHB - General-Head Boundary

- CHD - Time-Variant Specified-Head

- SIP - Strongly Implicit Procedure

- OC - Output Control

\section{Model Grid and Layers}

To implement the finite-difference model, the Delta was discretized into a rectangular grid of 1-mile square cells by row and column. The grid is oriented north-south and is divided into 184 rows of 73 columns (fig. 13). The part of the grid covering the Delta area has 7,101 active cells representing 7,101 square miles. The north-south orientation of the grid is consistent with the alignment of the lateral flow boundaries, and allows cell faces to be generally perpendicular to the regional flow directions. Lateral anisotropy ratio of 1:1 was used for simulation, and unique hydrogeologic properties were assigned to the center of each cell, defined as a node, by mathematical interpolation from observed point values.

The model is vertically discretized into one active layer simulating the sand and gravel of the Mississippi River alluvial aquifer. The areal extent of the layer reflects the areal extent of the alluvial aquifer in the Mississippi Delta. Because the topstratum (confining unit) extends over most of the Delta, the model layer is simulated to allow for both confined and watertable conditions. Under water-table conditions, the model recomputes transmissivity values for each cell as changes occur in the saturated thickness. The underlying aquifers are represented as a boundary condition. Although the underlying aquifers extend beyond the Delta area, they are not simulated beyond the areal extent of influence on the alluvial aquifer. The vertical impedance to flow between the alluvial aquifer and the 


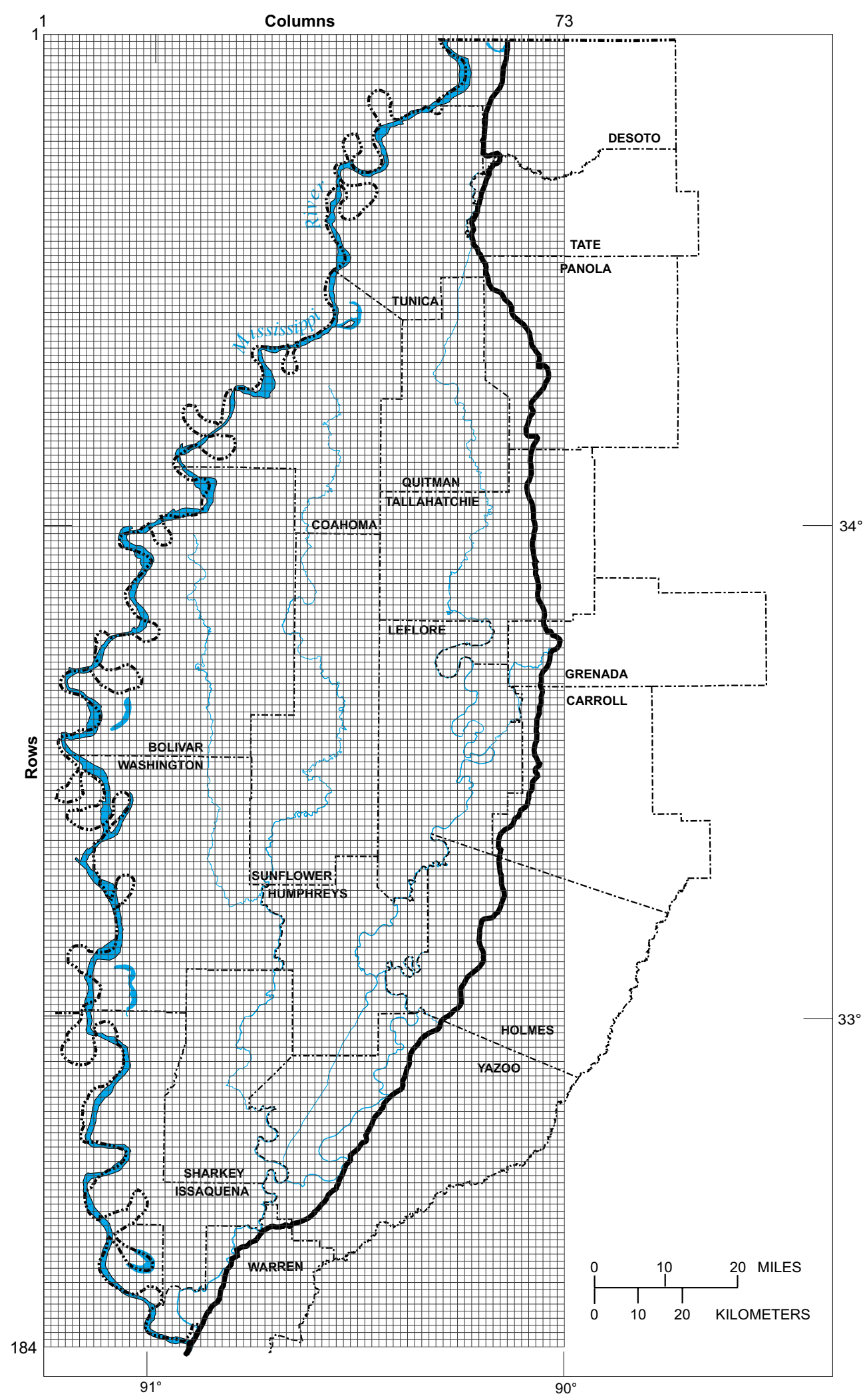

Figure 13. Model grid orientation. 
underlying aquifers is implemented in the model by using an areal distribution of leakance values of the model layer based on the thickness of the clay beds (determined by Arthur, 1994) separating the alluvial aquifer from the underlying aquifer.

\section{Model Boundaries}

Proper representation of model boundary conditions is one of the most important functions in the simulation of an aquifer system. Model boundaries are selected to simulate the actual hydrologic boundaries as realistically as possible. The lateral and upper and lower boundaries in a model control the simulated flow system by determining the location and the magnitude of the water that naturally enters and leaves the model.

The lateral boundaries of the alluvial aquifer are quite distinct, as the lens shape of the Delta results in the aquifer having only a western and an eastern lateral boundary. The western boundary is the Mississippi River, which penetrates nearly the full thickness of the aquifer in most areas along the river, and as a result, is in almost complete hydraulic connection with the aquifer. Aquifer heads along the western boundary are virtually equal to the stage of the river and are simulated in the model as time-variant specified heads. The specified heads are equal to the average stage in the Mississippi River for each stress period simulated in the model. The average water level for each month at seven gaging stations on the Mississippi River between Memphis, Tennessee, and Vicksburg, Mississippi, were used to estimate the specified heads at the western boundary (table 3 ). The eastern model boundary coincides with the western edge of the Bluff Hills. Underlying the Bluff Hills are water-bearing deposits (predominately the Cockfield and Sparta aquifers) that abut the alluvial plain. The eastern model boundary is simulated as a general head boundary with the heads at the boundary representing the potentiometric surfaces of the Cockfield and Sparta aquifers and terrace deposits underlying the Bluff Hills (fig. 14). The potentiometric maps of the Cockfield and Sparta aquifers constructed by Darden $(1986,1987)$ and Oakley and Burt (1994a, b) indicate that the water levels in the Cockfield and Sparta aquifers at the eastern boundary have changed little with time. The heads are assumed to be constant throughout the simulation period, but can be varied if hydrologic conditions change. The hydraulic conductances at the eastern boundary (general head boundary) reflect the hydraulic conductivity of the abutting aquifers and terrace deposits, the area of contact between the alluvial aquifer and the adjacent aquifer, and the length of the flow path.

The lower boundary represents the Sparta or the Cockfield aquifer, whichever of the two aquifers directly underlies the alluvial aquifer at a given location. The heads at the lower boundary represent the potentiometric surfaces of the Sparta and Cockfield aquifers (fig. 15). The heads at the lower boundary are unique for each cell. The potentiometric-surface maps constructed by Darden $(1986,1987)$ and Oakley and Burt (1994a, b) indicate little change in water levels in the underlying aquifers from 1984 to 1988 . Consequently, the lower boundary water levels were held constant throughout the simulation period. The flow interaction between the alluvial aquifer and the lower boundary is determined by the head difference between the alluvial aquifer and the underlying aquifer and the thickness and hydraulic conductivity of the separating deposits. The thickness of the lower confining unit of the alluvial aquifer is described by Arthur (1994) and is shown in figure 2 of the referenced report.

The upper or surficial boundary of the alluvial aquifer is the most complex to conceptually represent in the flow model. The upper boundary is simulated by using head-dependent-flux cells implemented by the river package (fig. 16) and specified flux cells implemented by the recharge package. The large stream channels and lake beds in the Delta are incised to varying depths into the sands, silts, and clays of the topstratum, and depending on the head difference between the alluvial aquifer and the surface-water body, water is either discharged from or recharged to the aquifer. The depth to which the major stream channels are incised into the topstratum was determined by using the thickness of the upper confining unit reported by Arthur (1994) and channel-bottom profiles constructed from fathometer surveys made during this study. During periods of high river and lake stages, these cells recharge water to the aquifer, and conversely, during periods of low stages, the head-dependent-flux cells represent aquifer discharge points. The magnitude of recharge and discharge is dependent upon the magnitude of the head difference between the river or lake and the aquifer, the area of the water body, and the thickness and hydraulic conductivity of the deposits between the surface-water body and the aquifer. Average monthly stages for the head-dependent-flux cells were determined by using the information presented in the U.S. Army Corps of Engineers annual data publica- 


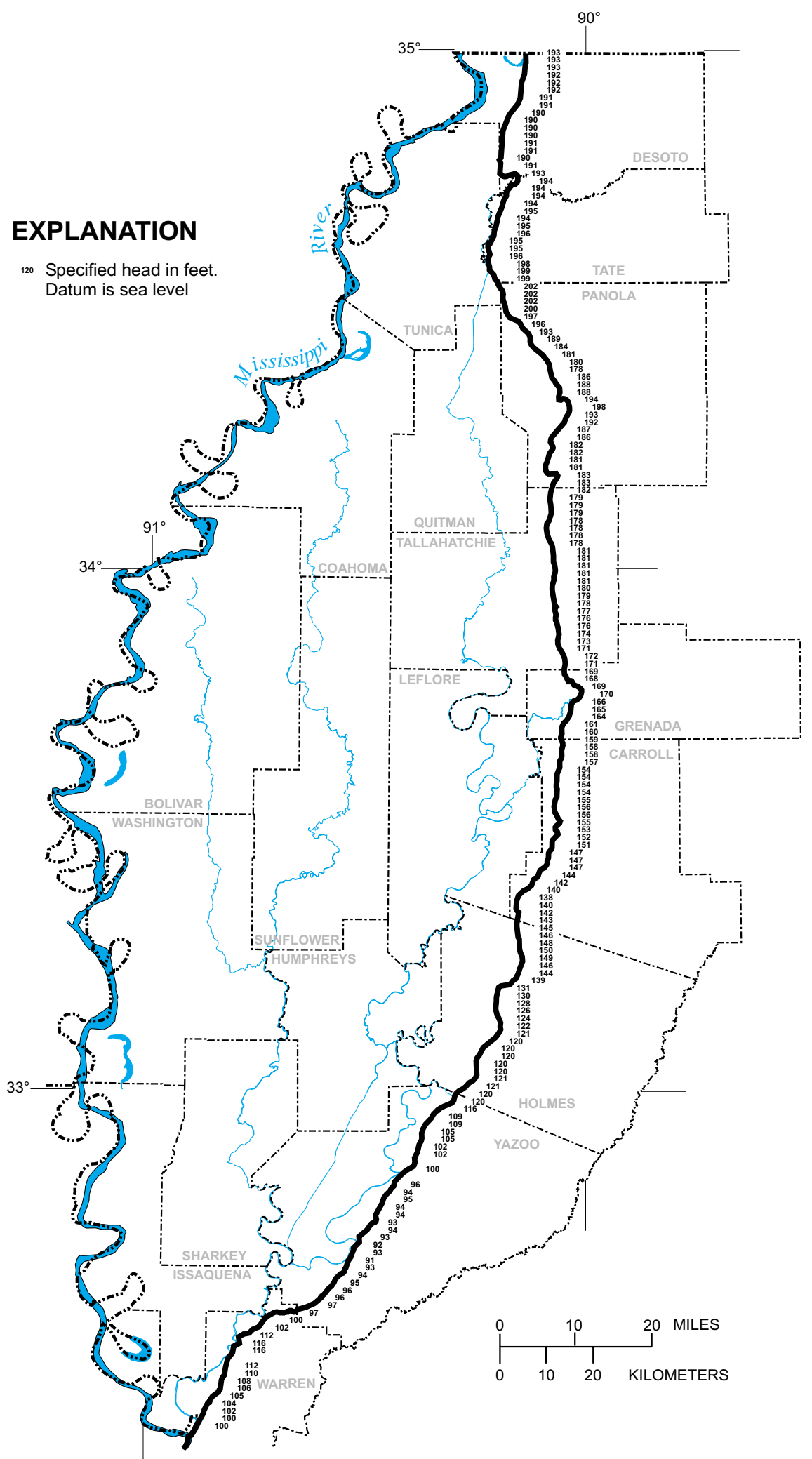

Figure 14. Specified heads at eastern model boundary. 
EXPLANATION

-120 П Potentiometric contour-Shows altitude at which water level would have stood in tightly cased wells. Hachures indicate depression. Interval 10 feet. Datum is sea level

Eastern boundary of study area

Sparta potentiometric surface

Cockfield potentiometric surface

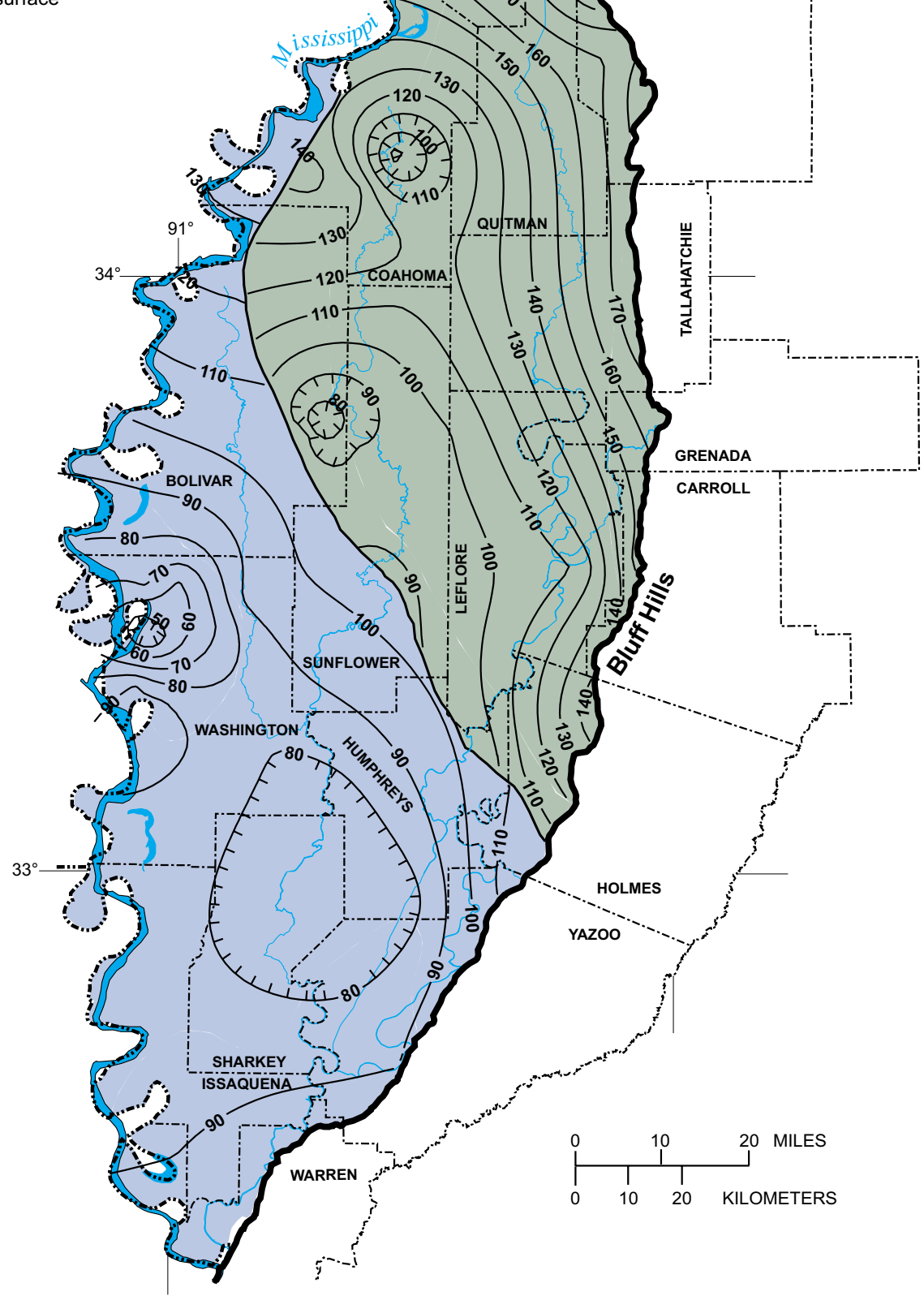

Figure 15. Potentiometric surface representing specified heads at the lower boundary. 


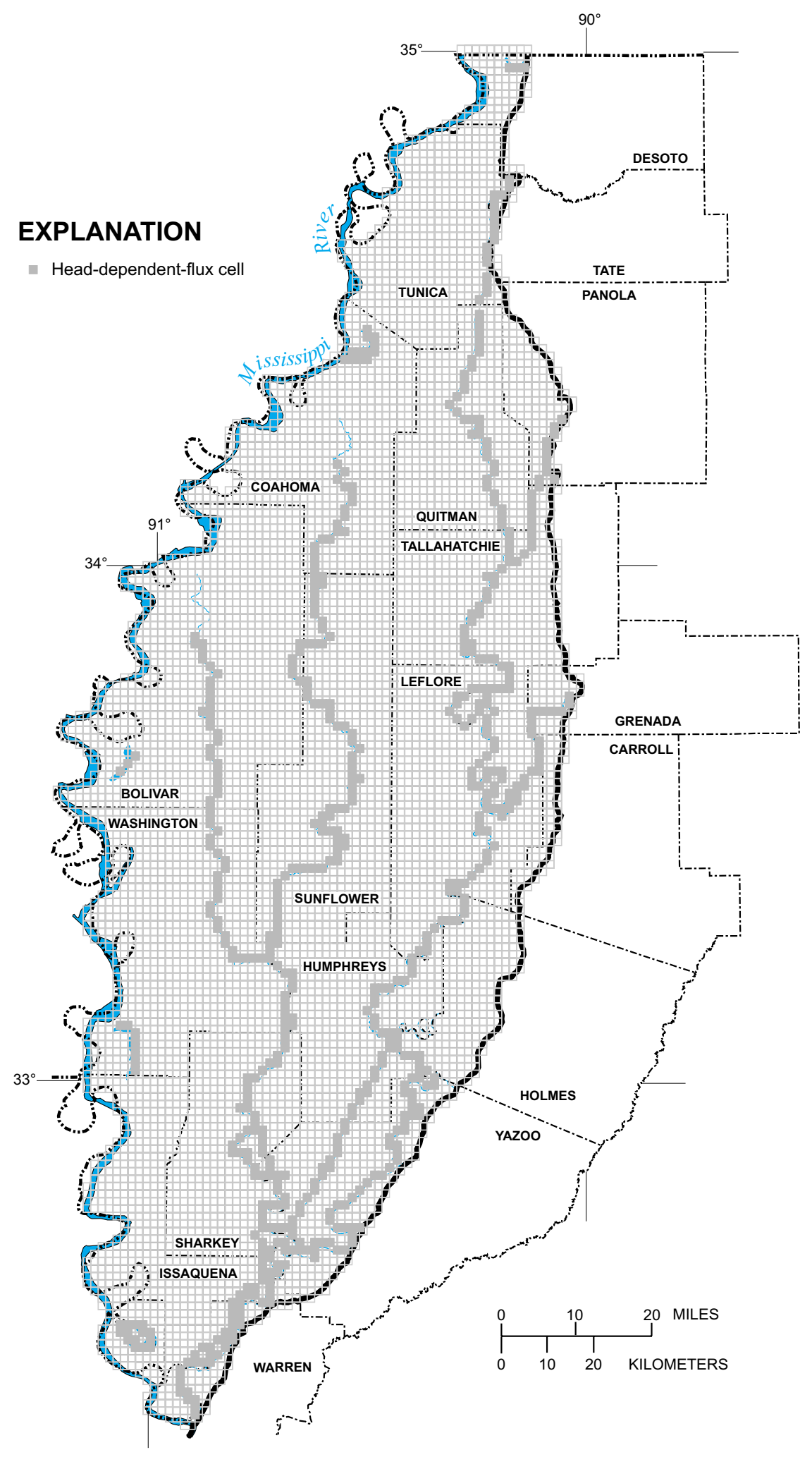

Figure 16. Location of river and lake head-dependent-flux cells (river package) in model. 
tion "Stages and Discharges of the Mississippi River and Tributaries" published by the Vicksburg and Memphis Districts.

Specified flux at the upper boundary simulates recharge to the alluvial aquifer from precipitation infiltrating through the topstratum. The complex depositional sequence of sands, silts, and clays that make up the topstratum form an upper confining unit that has a wide range of transmissive and storage characteristics. The temporal distribution of recharge from precipitation at the upper boundary is determined by the monthly rainfall totals at Stoneville, Mississippi and by the thickness of the clay beds in the topstratum. During the simulation period, monthly rainfall at Stoneville, Mississippi, ranged from 0.45 inch in August 1994 to 16.93 inches in April 1991 (table 2). The stratigraphic thickness of the upper confining unit of the alluvial aquifer ranged from less than 10 feet to greater than 100 feet (as shown in figure 1 in the report by Arthur, 1994). Because of the complex sequence of sand, silt, and clay beds in the topstratum, the thickness of the upper confining unit was reduced 10 feet to better represent the aggregate clay thickness. The thickness of the alluvial aquifer was increased by 10 feet to represent the interbedded sand in the topstratum and to account for the uncertainty of the altitude of the base of the upper confining unit.

\section{Calibration Strategy}

Model calibration is the attempt to minimize the difference between the model-generated results and the corresponding measured data by adjusting model input values. Calibration was accomplished for the alluvial aquifer model by adjusting model input values of horizontal hydraulic conductivity of the alluvial aquifer, vertical hydraulic conductivity of the lower confining unit, riverbed conductance of the internal streams and lakes, hydraulic conductance of the interface at the eastern boundary between the alluvial aquifer and the laterally adjacent aquifers, and areal recharge from precipitation and miscellaneous sources until an acceptable error was achieved between the model generated heads and the measured water levels in the alluvial aquifer. The model input values for each parameter were constrained within a range of values reported to be representative for the Mississippi River alluvial plain.

The model was constructed and calibrated to simulate transient hydrologic conditions in the Delta from January 1988 through December 1996. Initial heads for transient simulation were determined by using the spring 1988 measured water levels. Steadystate construction and calibration was not considered acceptable for the Mississippi River alluvial model. Even in predevelopment time, water levels in much of the alluvial aquifer probably never approached equilibrium conditions. Fluctuating seasonal water levels caused by short-term variations in rainfall and large stage variations on the Mississippi River and internal streams and lakes resulted in the alluvial aquifer never approaching definable long-term equilibrium conditions. A seasonal average predevelopment potentiometric surface could not be determined with sufficient accuracy to develop and calibrate a predevelopment steady-state model. Consequently, development and calibration of a steady-state model accurately representing pumping conditions was even less likely.

The dominant basis for transient model calibration was the water-level measurements made at more than 300 alluvial aquifer wells during May and October of each year of the simulation period. The seasonal change in hydrologic conditions in the Delta and the apparent sensitivity of the alluvial aquifer to these changes necessitated that time be discretized sufficiently to reflect this temporal sensitivity and to avoid significant temporal truncation error. Time was discretized in the model by having each stress period represent hydrologic conditions for 30.4 days (length of an average month). Thus, for each of the 108 stress periods in the model, pumpage, areal recharge, and river and lake stages were updated in the model. Water levels in the alluvial aquifer for each month of the 9-year simulation period were generated by the model. The model-generated May and October water levels for each year of the simulation (17 stress periods) were compared to the corresponding measured water levels. The average root-mean-square (RMS) error determined for the calibrated model was 4.55 feet (table 4 ). The RMS error ranged from 3.86 feet for stress period 22 (fall 1989) to 5.58 feet for stress period 46 (fall 1991).

Simulated hydrographs and measured water levels in the alluvial aquifer for wells B012 in Coahoma County, N046 in Sunflower County, and A022 in Tallahatchie County (fig. 1) are presented in figure 17. Well B012 is less than 3 miles from the Mississippi River, and the water level in the well is greatly influenced by the stage of the river. Measured water levels in well B012 ranged from about 141 to 167 feet above sea 
Table 4. Root-mean-square error (in feet) of simulated water levels in the Mississippi River alluvial aquifer

\begin{tabular}{lccccccccccccccccc}
\hline & Fall & Spr & Fall & Spr & Fall & Spr & Fall & Spr & Fall & Spr & Fall & Spr & Fall & Spr & Fall & Spr & Fall \\
& 88 & 89 & 89 & 90 & 90 & 91 & 91 & 92 & 92 & 93 & 93 & 94 & 94 & 95 & 95 & 96 & 96 \\
\hline Stress period & 10 & 17 & 22 & 29 & 34 & 41 & 46 & 53 & 58 & 65 & 70 & 77 & 82 & 89 & 94 & 101 & 106 \\
No. of wells & 391 & 387 & 364 & 389 & 340 & 354 & 356 & 383 & 425 & 439 & 446 & 467 & 449 & 461 & 467 & 478 & 451 \\
RMS error & 4.81 & 4.76 & 3.86 & 4.32 & 4.43 & 4.31 & 5.58 & 4.15 & 4.23 & 4.42 & 3.88 & 4.81 & 4.71 & 5.05 & 4.83 & 4.75 & 4.56 \\
\hline
\end{tabular}

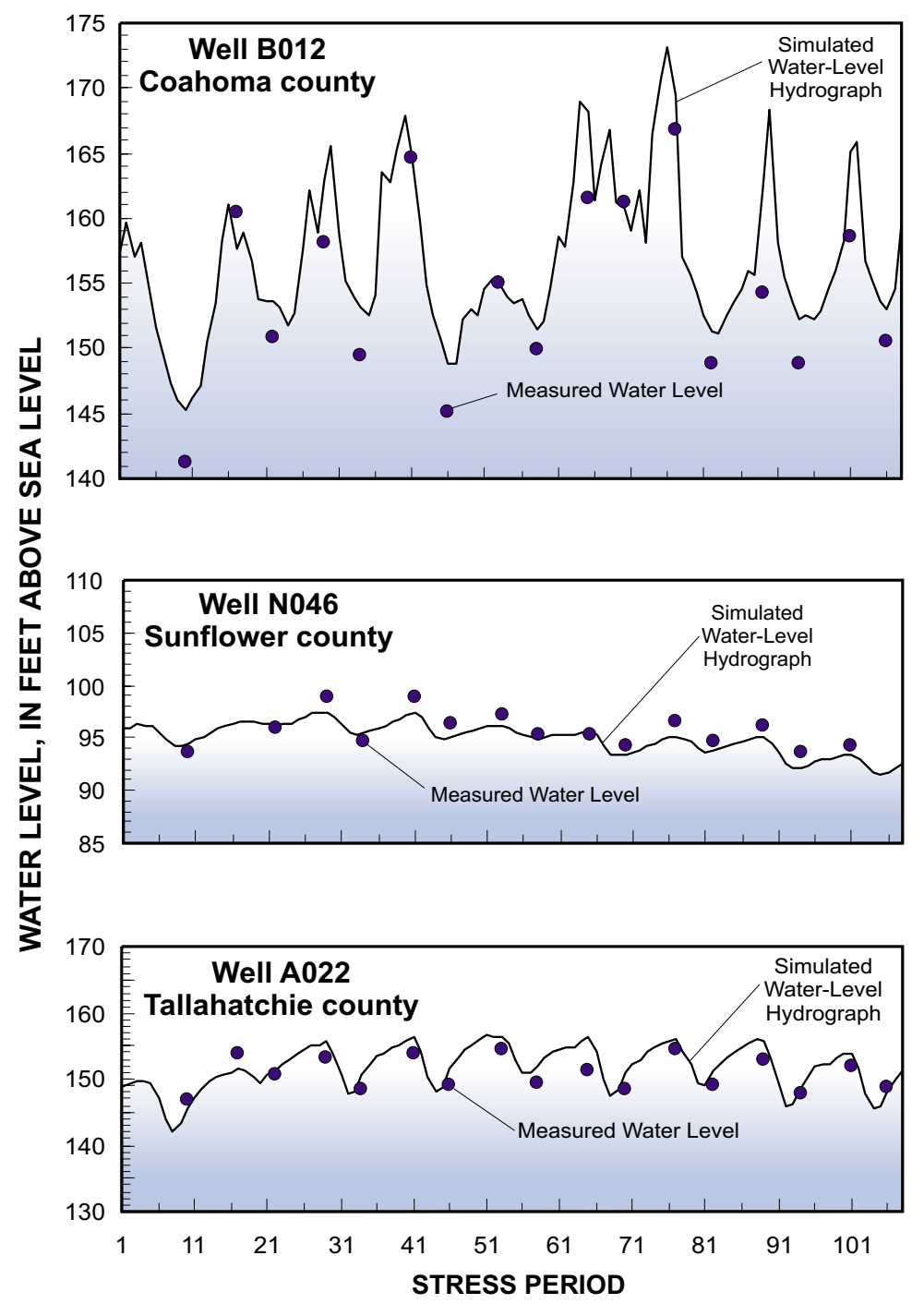

Figure 17. Simulated and measured water levels at selected observation wells completed in the Mississippi River alluvial aquifer. 
level, due mainly to the fluctuation of the stage of the Mississippi River. The simulated hydrograph for well B012 is a reasonable representation of the measured water levels. Well N046 is located in south-central Sunflower County in the heavily-pumped central Delta area. Water levels in well N046 fluctuate much less than water levels in well B012. The seasonal waterlevel change in well N046 was less than 5 feet during the simulation period. The water-level trend in well N046 is downward about 1/2 foot per year, and the simulated hydrograph at this well presents a close representation of this trend. Well A022 at the eastern edge of the Delta in northern Tallahatchie County is within 2 miles of the Bluff Hills. Measured water levels in well A022 fluctuate about 5 feet seasonally, and during the simulation period the water-level trend has been slightly downward. The simulated hydrograph for well A022 is a reasonable representation of the measured water levels for this well.

The OLWR measures water levels in the alluvial aquifer on a section that runs from west to east from southern Washington County, across Humphreys County, and into Holmes County. Measured water levels for spring and fall 1994 and simulated water levels

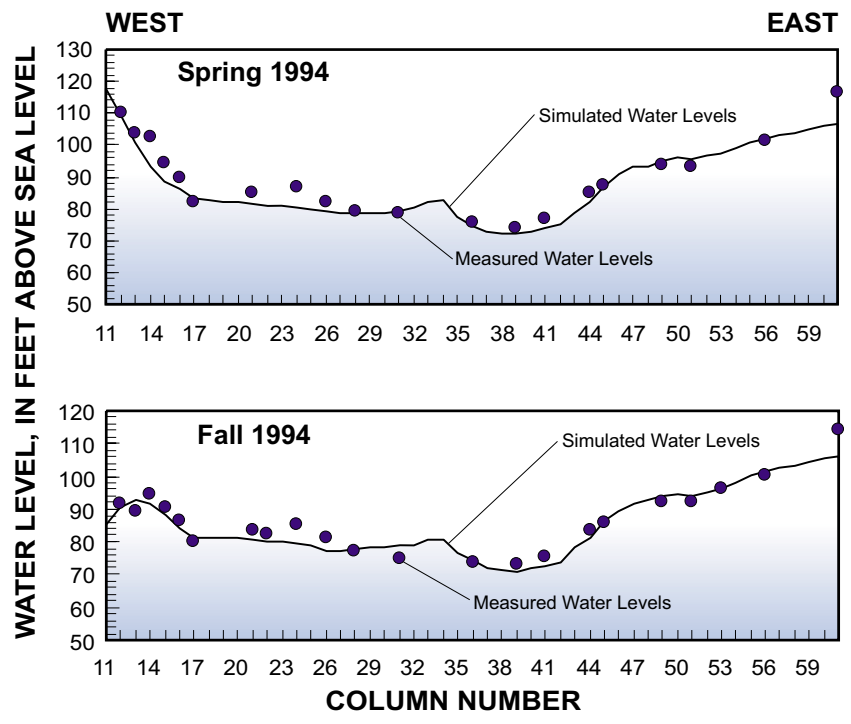

Figure 18. Simulated and measured west-to-east water-level sections across the Delta for spring and fall 1994.

along this section are shown in figure 18. In 1994 the Mississippi River stage varied about 34 feet from spring to fall. The 1994 water levels were chosen to show the error of model-generated water levels along the section and to show the influence of the Mississippi
River stage on water levels at the western edge of the Delta. Model results indicate that the western boundary of the alluvial model is properly simulated at the western edge of this section.

The measured and simulated 1996 spring and fall potentiometric surfaces for the alluvial aquifer are shown in figure 19. The 1996 potentiometric surfaces are shown to illustrate the error between the measured and simulated surfaces; 1996 is the last year of the transient simulation and should show the cumulative results of any gross error. Both spring and fall simulated surfaces seem to be reasonable representations of the measured potentiometric surfaces.

\section{Hydraulic Properties}

Hydraulic properties that determine the transmissive, storage, leakage, and recharge capabilities of the alluvial aquifer were tested through a range of values and boundary conditions to generate the best-fit distribution between observed and simulated water levels. The tested values for each hydraulic property were constrained within a range of values considered reasonable as determined from examination of information presented in previous studies. A summary of the hydraulic values used in the calibrated model is presented in table 5.

The calibration procedure resulted in a horizontal hydraulic conductivity of 425 feet per day for the alluvial aquifer, which is in close agreement with the 400 feet per day reported by Sumner and Wasson (1990) for their model of the aquifer. Since the aquifer acts as both a confined and unconfined aquifer depending upon the altitude of the water level in relation to the top of the aquifer, the transmissivity of the aquifer depends upon the saturated thickness as well as the total thickness of the aquifer. The thickness of the aquifer used in this calibrated model is based on the thickness of the coarse sand and gravel reported by Arthur and Strom (1996). The areal distribution of simulated transmissivity for October 1996 is shown in figure 20. The simulated transmissivity is between 30,000 and 50,000 feet squared per day over most of the Delta. Because the aquifer is under confined conditions at times, mostly adjacent to the Bluff Hills and near the Mississippi River when the river is at a high stage, a storage coefficient and a specific yield were required for model simulation. A storage coefficient of 0.016 and a specific yield of 0.32 were used in the calibrated model, as compared to values of 0.001 and 0.30 , respectively, used by Sumner and Wasson (1990). 

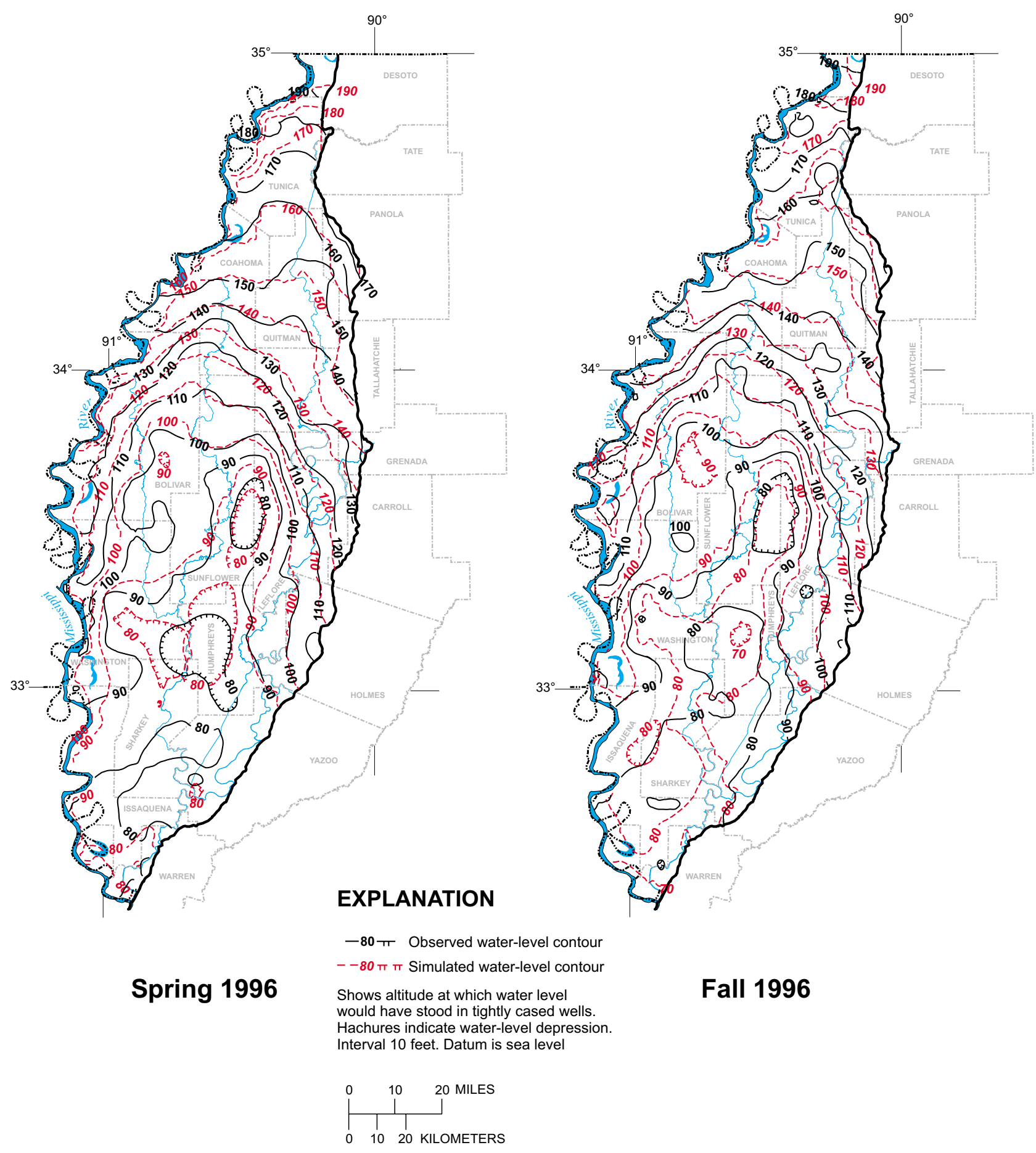

Fall 1996

Figure 19. Observed and simulated spring and fall 1996 potentiometric surfaces of the Mississippi River alluvial aquifer. 
Table 5. Summary of the principal hydraulic values used in the calibrated model

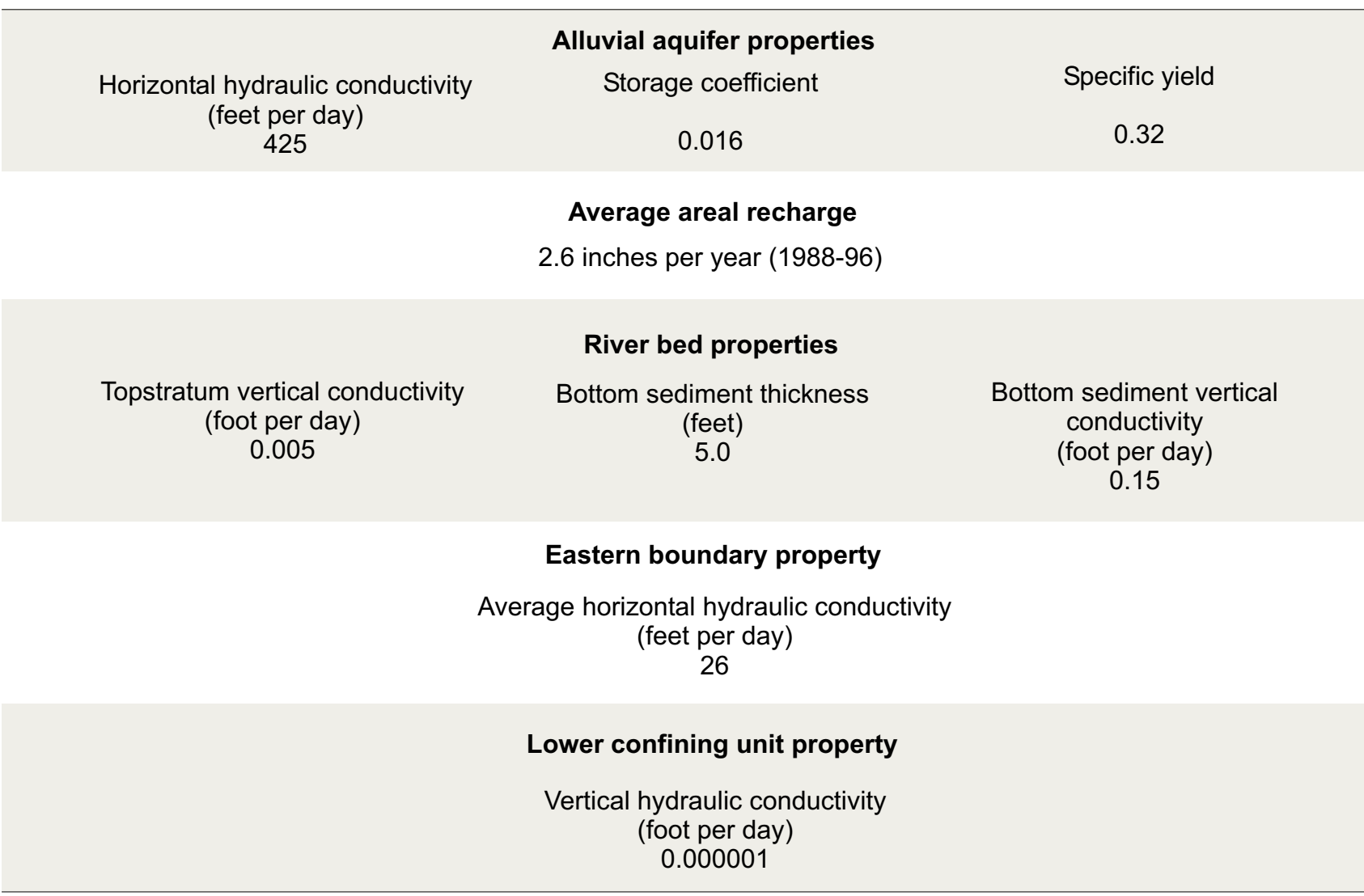

The average annual areal recharge for the calibrated model was 2.6 inches per year. Areal recharge was varied monthly depending upon the magnitude of the corresponding monthly rainfall totals at Stoneville, Mississippi.

The riverbed properties used in the river package of the calibrated model have a substantial effect on the amount of water that flows between the alluvial aquifer and surface-water bodies simulated in the model. The model incorporates 557 cells of the 7,101 active cells into the river package to represent the interaction of the internal rivers and lakes with the alluvial aquifer. Channel fathometer data collected during this study, and river channel cross sections from the U.S. Army Corps of Engineers and from previous U.S. Geological Survey studies were used to help determine channel incisement, channel widths, and channel bottom consistency (Harbeck and others, 1961). For stream channels that did not penetrate the entire thickness of the topstratum, the calibrated riverbed hydraulic conductivity is 0.005 foot per day. For surface-water bodies that penetrated the entire thickness of the topstratum, a streambed sed- iment depositional thickness of 5 feet between the flowline of the channel and the aquifer was assumed. The hydraulic conductivity of the 5-foot thickness of riverbed sediments in the calibrated model was determined to be 0.15 foot per day.

The eastern boundary of the model represents the water-bearing units (Cockfield Formation, Sparta Sand, and terrace deposits) adjacent to the alluvial aquifer and underlying the Bluff Hills at the eastern edge of the Delta. The hydraulic conductance at the eastern boundary was computed using the thickness of the alluvial aquifer at the general head boundary cell, a unit width, a unit flow length, and an average hydraulic conductivity of the adjacent sediments determined during the calibration process. The average horizontal hydraulic conductivity of the sediments at the eastern boundary used to compute the conductance at the general head boundary in the calibrated model is 26 feet per day.

The clay beds directly underlying the alluvial aquifer represent the lower confining unit. The thickness of the clay beds of the lower confining unit ranges 


\section{EXPLANATION}

Simulated transmissivity,

in feet squared per day

90,000
70,000
50,000
30,000
10,000
5,000

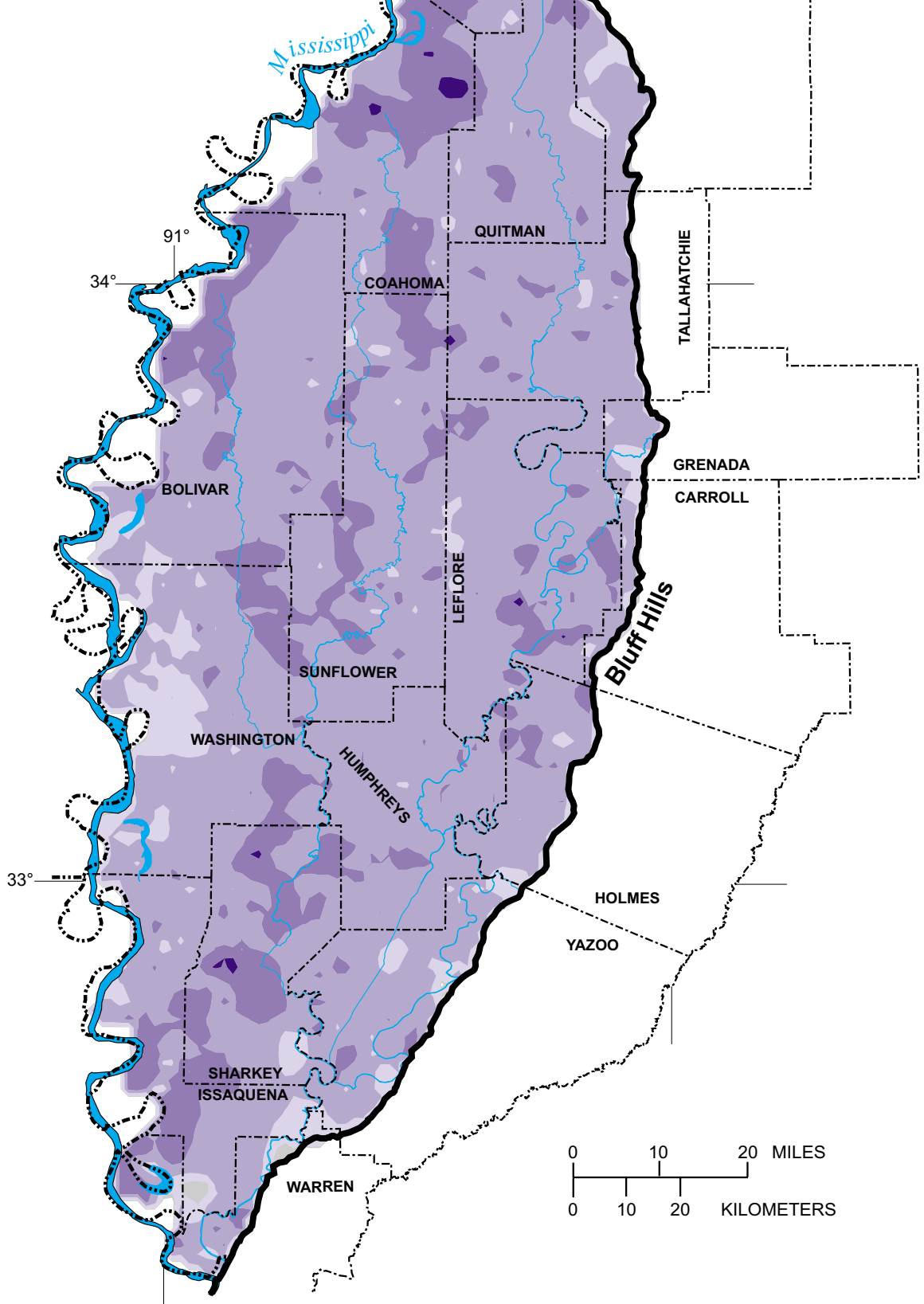

Figure 20. Simulated transmissivity of the Mississippi River alluvial aquifer for fall 1996. 
from less than 10 feet to greater than 500 feet (Arthur, 1994). As the result of the calibration process, the vertical hydraulic conductivity of the underlying clay beds was determined to be 0.000001 foot per day.

\section{Model Sensitivity}

To determine the sensitivity of the model simulation results to changes in hydraulic properties, a selected property was varied independently from 0.2 to 5 times its calibrated value. Because water levels are the most easily quantified aquifer characteristic, the RMS error of simulated water levels compared to measured water levels was used to assess the sensitivity of the model to a particular change in value. The sensitivity of model results to independent changes in areal recharge, horizontal hydraulic conductivity of the alluvial aquifer and water-bearing units at the eastern boundary, and to changes in vertical hydraulic conductivity of river bed sediments is shown in figure 21 . Sensitivity analysis indicates that of the four calibration parameters shown in figure 21 , the model is most sensitive to changes in areal recharge to the alluvial aquifer. The model is least sensitive to changes in riverbed vertical hydraulic conductivity. The model was more sensitive to an increase in areal recharge than to a corresponding decrease in areal recharge. This characteristic held true with changes in general head boundary horizontal hydraulic conductivity.

\section{GROUND-WATER FLOW ANALYSIS}

The calibrated model simulates the Mississippi River alluvial aquifer flow system in the Mississippi Delta from January 1988 through December 1996. The flow analysis represents the results of 108 monthly stress periods. The analysis includes a brief discussion of the magnitude and distribution of pumpage from the alluvial aquifer and a detailed discussion of the sources and magnitudes of recharge to and natural discharge from the alluvial aquifer. The analysis concludes with a flow budget showing sources and magnitudes of flow into and out of the alluvial aquifer flow system.

\section{Pumpage}

Pumpage rate estimates for the alluvial aquifer used in the calibrated model were totaled monthly from January 1988 through December 1996. Pumpage rates for agriculture in the Delta were determined by the
YMD. Pumpage rates for nonagricultural uses were provided by the OLWR. Almost all of the pumpage from the alluvial aquifer during the model simulation period was for agriculture and for catfish production. The annual pumpage rates used in the calibrated model are shown in figure 22. The greatest annual pumpage rate from the alluvial aquifer used in the calibrated model was about 1,620 million gallons per day during 1995. The smallest annual pumpage rate used in the calibrated model was about 620 million gallons per day during 1989. During 1989, rainfall in the Delta was about 15 inches greater than normal, and irrigation demand was at a minimum. The average annual pumpage rate from the alluvial aquifer used in the calibrated model for the simulation period was about 1,270 million gallons per day.

Most of the pumpage from the alluvial aquifer is concentrated in the central part of the Delta in Bolivar, Sunflower, Leflore, and Humphreys Counties. Bolivar County had the greatest annual pumpage rate from the alluvial aquifer of the 19 counties in the Delta during the simulation period with about 20 percent of the total annual pumpage. Bolivar County, covering 892 square miles, is the largest county in the Delta, and has the greatest rice acreage. Sunflower County has the second greatest annual pumpage rate accounting for about 16 percent of the total annual pumpage in the Delta. Areas of concentrated pumpage where withdrawals were greater than 0.5 million gallons per day per square mile during 1996 are shown in figure 23.

\section{Recharge and Discharge}

Recharge to and natural discharge from the alluvial aquifer occur at lateral and vertical aquifer boundaries in the Mississippi Delta. The magnitude of the recharge and discharge is highly variable and is dependent upon hydrologic conditions both inside and outside of the Delta area.

\section{Lateral}

Lateral recharge and discharge are important flow components in the alluvial aquifer flow system. The lens shape of the Delta with the Bluff Hills to the east and the Mississippi River to the west limits lateral flow at the perimeter of the Delta to these two boundaries. 


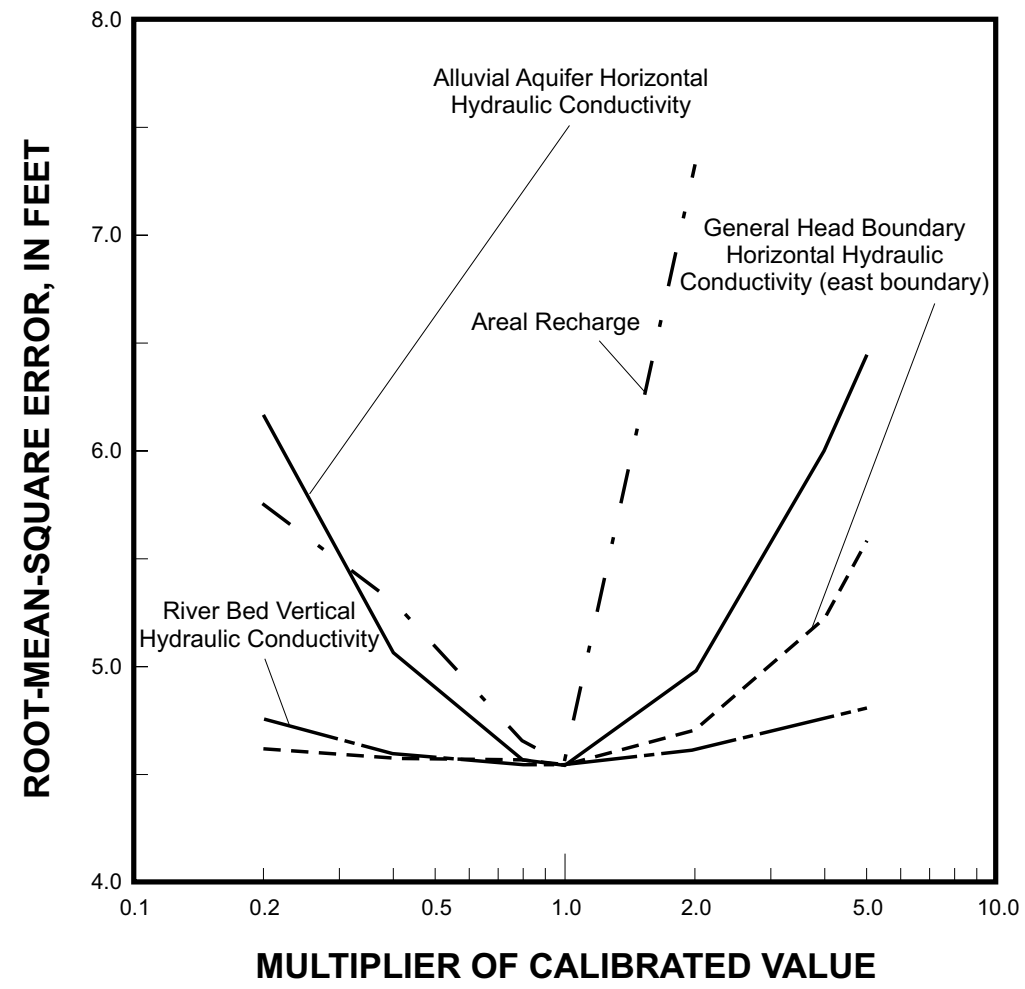

Figure 21. Model sensitivity to independent changes in selected calibration parameters.

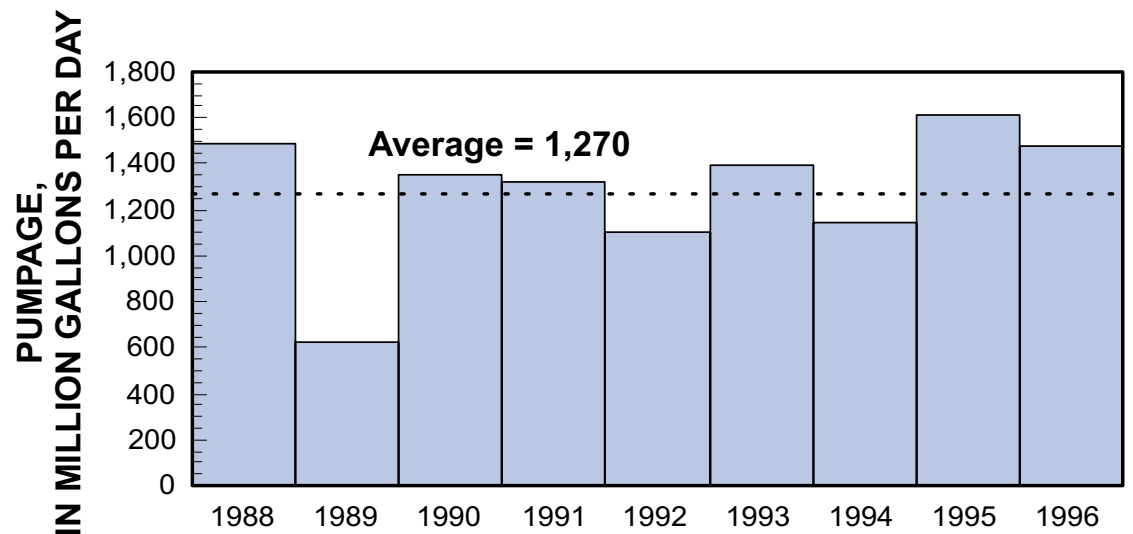

Figure 22. Annual pumpage rate from the Mississippi River alluvial aquifer used in the calibrated model. 
Areas with pumpage greater than 0.5 million gallons per day per square mile

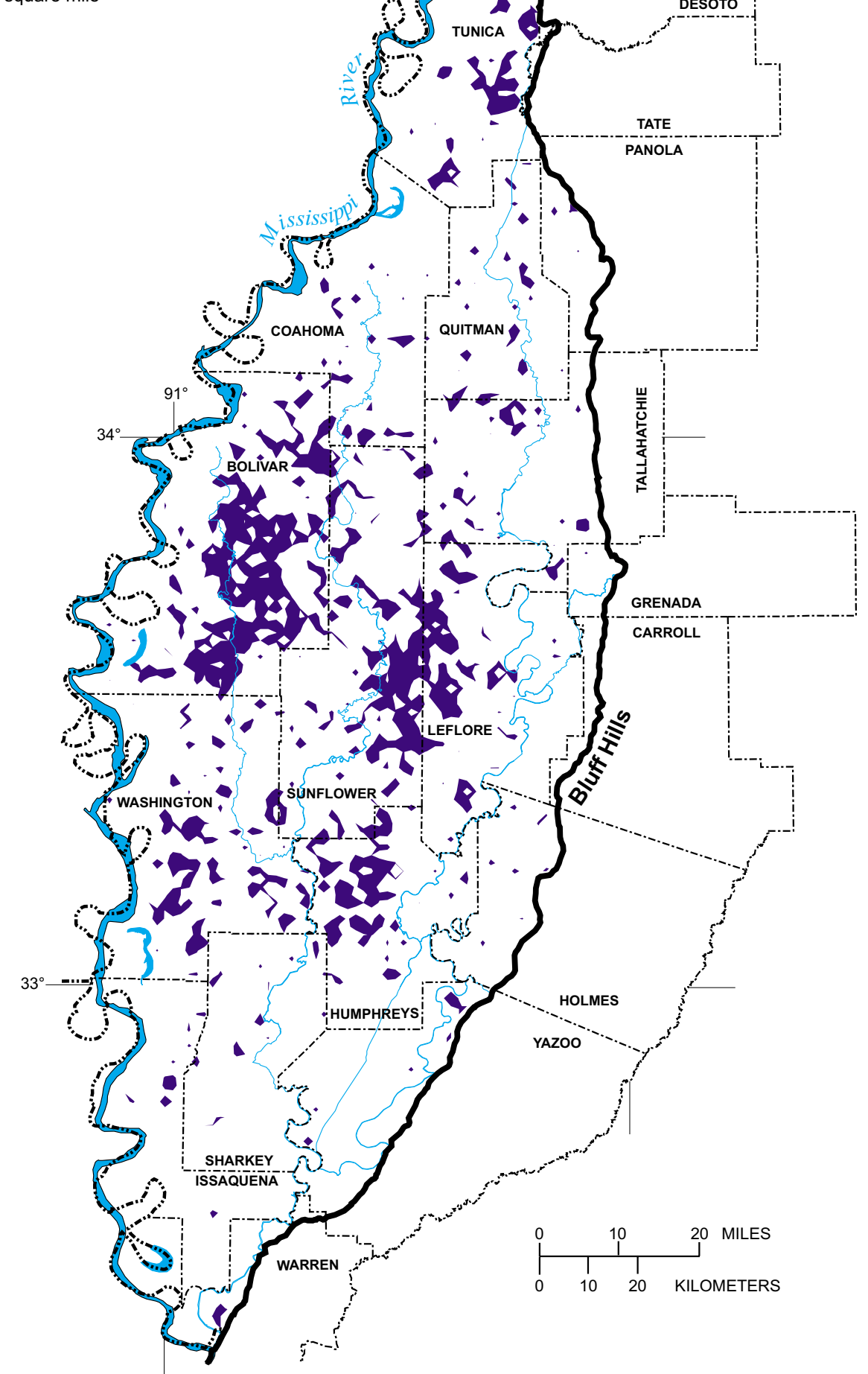

Figure 23. Areas of concentrated pumpage from the Mississippi River alluvial aquifer in 1996. 


\section{Bluff Hills}

The water-bearing units underlying the Bluff Hills (Cockfield Formation, Sparta Sand, and terrace deposits) have water levels that historically are greater than water levels in the alluvial aquifer at adjacent locations, resulting in water moving laterally from these units into the alluvial aquifer. Higher water levels in these units are the result of the relatively high altitude of their recharge areas as compared to the altitude of the alluvial plain. In the calibrated model, the water levels underlying the Bluff Hills were held constant for the simulation period (fig. 14). The potentiometric maps made by Darden $(1986,1987)$ and by Oakley and Burt (1994a, b) indicate that water levels in these units adjacent to the edge of the Delta changed very little from 1984 to 1988 . No large pumping centers are withdrawing water from these units where these units directly underlie the Bluff Hills. Along the entire length of the eastern edge of the Delta, the alluvial aquifer receives recharge from these sediments. The magnitude of the recharge is dependent upon the head difference between the adjacent aquifer and the alluvial aquifer, the hydraulic conductivity of the adjacent sediments, and the area of lateral contact. The north-tosouth distribution of lateral recharge is relatively uniform, but less recharge occurs where the Yazoo Clay directly underlies the Bluff Hills (fig. 3), and greater recharge occurs from Vicksburg to about 20 miles north of Vicksburg due to large head differences. In the southern one-third of the Delta, a substantial part of the lateral recharge probably is intercepted by the Yazoo River due to the proximity of the river to the edge of the Bluff Hills. During the 9-year simulation period, the lateral recharge to the alluvial aquifer along the eastern edge of the Delta averaged about 108 cubic feet per second and ranged annually from 102 to 114 cubic feet per second. The result of long-term lateral recharge of water with low dissolved solids concentrations at the eastern edge of the Delta is indicated by the low specific conductance values of alluvial aquifer water in this area (fig. 12). Lateral recharge at the eastern edge of the Delta from water-bearing units laterally adjacent to the alluvial aquifer should be relatively stable for the foreseeable future if rainfall remains about normal and no large pumping centers are established in the waterbearing units underlying the Bluff Hills or in the alluvial aquifer adjacent to the Bluff Hills. Also, any large channel constructed in the Delta parallel to and adjacent to the foot of the Bluff Hills and deep enough to penetrate the saturated zone may intercept some water that would flow westward to the central part of alluvial aquifer.

\section{Mississippi River}

The Mississippi River on the western boundary of the Delta is a lateral recharge/discharge area for the alluvial aquifer. The great depth of the river channel (as much as 100 feet deep) allows most of the area along the river to be in almost complete hydraulic connection with the aquifer. Depending upon the stage of the Mississippi River, the aquifer is either recharged by water from the river or the aquifer is discharging water to the river. Long-term net flow between the Mississippi River and the alluvial aquifer is probably small, but model simulations indicate that during periods when the river is at an extremely high stage or extremely low stage, the local recharge rate to and discharge rate from the alluvial aquifer in most areas along the river is large.

During the 9-year simulation period of the calibrated model, the resultant net flow between the Mississippi River and the alluvial aquifer was small considering the large amounts of water that flowed locally back and forth between the aquifer and the river. The greatest average annual recharge to the alluvial aquifer from the Mississippi River during the simulation period was about 590 cubic feet per second during 1993. The average stage of the Mississippi River in 1993 was the highest during the simulation period. The average stage of the river at the Greenville, Mississippi, gage (about midway between Vicksburg and Memphis) during 1993 was 38.6 feet. The greatest average annual discharge from the alluvial aquifer to the Mississippi River during the simulation period was about 894 cubic feet per second during 1988. The average stage of the Mississippi River in 1988 was the lowest during the simulation period. The average stage of the river at the Greenville, Mississippi, gage during 1988 was 19.9 feet. The relation between the average annual stage of the Mississippi River at the Greenville gage and simulated recharge to the alluvial aquifer from the Mississippi River is shown in figure 24 . The relation indicates that on an annual basis, net recharge to the alluvial aquifer from the Mississippi River starts when the average annual stage at the Greenville gage reaches about 30 feet. The datum of the Greenville gage is 74.92 feet above sea level. Simulation results indicate that a significant long-term change in the average stage of the Mississippi River will have corresponding changes in water levels in the alluvial aquifer adjacent 
to the river, and will affect recharge to the aquifer from the river and discharge from the aquifer to the river.

Model-simulated and measured water levels indicate that in most areas within about 6 miles of the Mississippi River, water levels in the alluvial aquifer are influenced by stages in the river (fig. 18). At high river stage, water is stored in the aquifer and will eventually discharge to the river during the next period of low river stage. If the timing was accurate, this water could be made available for many purposes within the Delta such as stream augmentation and other water uses. Although, currently (2000) the development of this source of water is probably not feasible, this resource is available for future consideration.

\section{Vertical}

Vertical recharge and discharge are important flow system components in the alluvial aquifer throughout the entire Delta, but more so in the central part of the Delta where lateral recharge and discharge have less effect on the flow system. The vertical recharge and discharge are the result of precipitation, flow to and from surface-water bodies, and flow to and from underlying aquifers and the alluvial aquifer.

\section{Precipitation}

Model simulation indicates that precipitation is the most important recharge component in the alluvial aquifer flow system in the Delta. The long-term average annual precipitation in the Delta is about 52 inches (table 2). Most of the rainfall runs off and flows into streams and lakes, evaporates, or transpires, but a small part of the annual precipitation infiltrates the ground and recharges the alluvial aquifer. The amount of infiltrated water depends on the amount and distribution of rainfall, the time of year, and the permeability of the topstratum. The amount of rainfall that recharges the alluvial aquifer is uncertain, and areal recharge has been reported and estimated over a wide range of values from about zero to about 5 percent of the annual precipitation. It is apparent that more study needs to be undertaken in the Delta to obtain a better understanding of the magnitude and distribution of recharge from rainfall.

The model calibration process indicated the importance of precipitation in providing recharge to the alluvial aquifer. Model simulation indicates that from 1988 to 1996 , about 86 percent of the recharge to the alluvial aquifer was from areal recharge. During this period, model simulation indicated that an average of about 2.6 inches per year of precipitation recharged the alluvial aquifer. The simulated recharge is about 5 percent of the average yearly precipitation. This value is substantially greater than the 0.5 inch per year areal recharge simulated for the alluvial aquifer from 1981 to 1983 by Sumner and Wasson (1990). The areal recharge used in the model was distributed spatially for each monthly stress period based on the thickness of the upper confining unit and the monthly rainfall total reported at Stoneville, Miss. Using this method to distribute areal recharge in the model, areal recharge ranged from a low of about 2.1 inches during 1988 to a high of about 3.1 inches during 1989. During the 9-year simulation period, the average annual rainfall at Stoneville was 53.6 inches. The annual rainfall at Stoneville was 40.77 inches during 1988 and 67.34 inches during 1989. The rainfall in 1988 and 1989 were the least and greatest, respectively, at Stoneville during the simulation period. Most of the areal recharge in the Delta occurs during the winter and spring months when precipitation is the greatest and evaporation and transpiration are at a minimum. The yearly areal recharge values used in the calibrated model during the simulation period are shown in figure 25.

\section{Surface Water}

Rivers, streams, lakes, and other surface-water bodies within the Delta are sources of vertical recharge and also discharge areas for the alluvial aquifer. Most of the recharge from the surface-water bodies occurs during winter and spring when streamflow is abundant, and most discharge from the alluvial aquifer occurs in late summer and fall as base flow to streams.

During the simulation period, net recharge to the alluvial aquifer from surface-water bodies averaged about 113 cubic feet per second. The greatest average recharge was about 511 cubic feet per second during 1989 when surface-water bodies were at higher than normal stages because of the large amount of rainfall during the year. In 1988, 1992, and 1995, the alluvial aquifer had a net loss of water to the surface-water bodies and discharged an average of about 21, 262, and 51 cubic feet per second of water, respectively, to the surface-water bodies. The rate of simulated flow of water between the surface-water bodies within the Delta and the alluvial aquifer during the model simulation period is shown in figure 26 . 


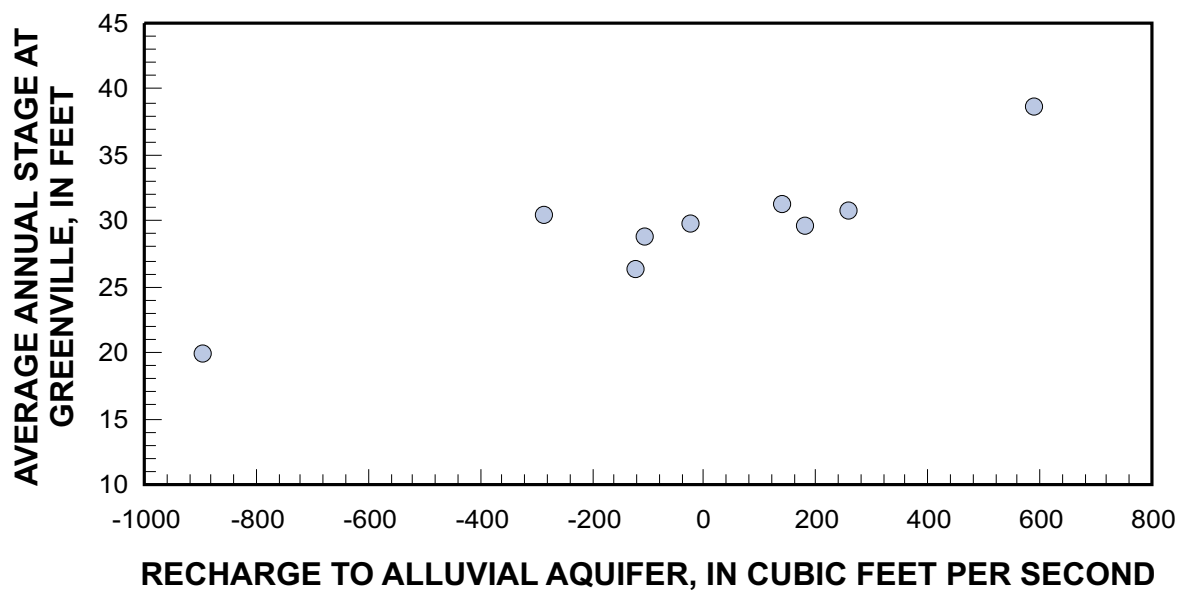

Figure 24. Relation between average annual stage of the Mississippi River at Greenville, Mississippi, and simulated recharge to the Mississippi River alluvial aquifer from the Mississippi River.

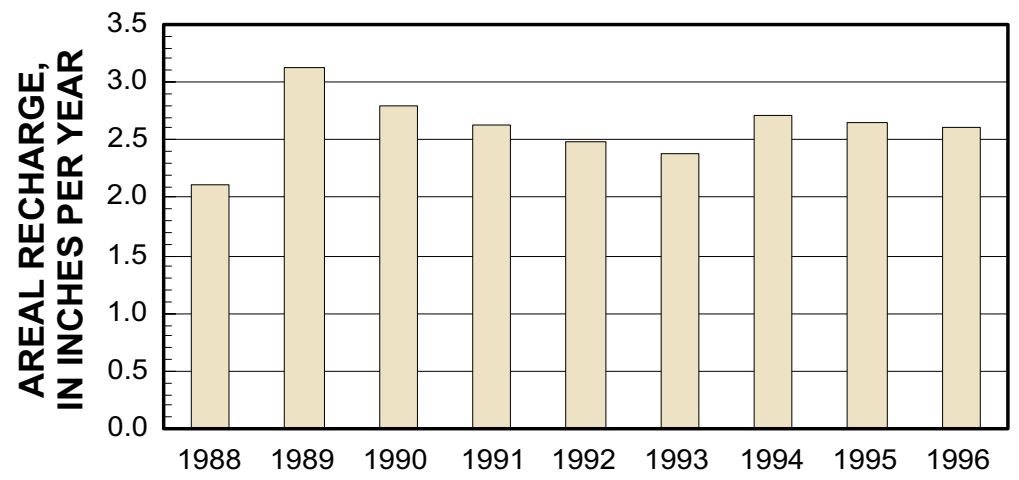

Figure 25. Simulated areal recharge to the Mississippi River alluvial aquifer, 1988-96.

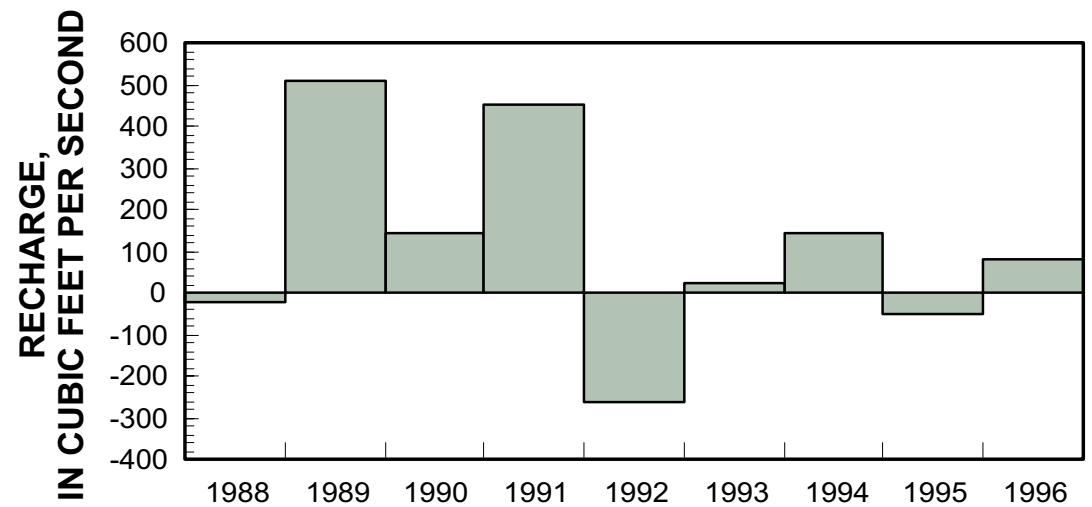

Figure 26. Simulated recharge to the Mississippi River alluvial aquifer from surface-water bodies within the Delta. 
Several of the major streams in the Delta have a large percentage of their drainage basins outside the Delta, and a large percentage of their discharges are regulated outflows from flood control reservoirs located outside the Delta. The Sunflower River is the only major river in the Delta with unregulated flow and a drainage basin contained totally within the Delta.

\section{Underlying Aquifers}

Model simulation results indicate that from 1988 to 1996, net flow between the alluvial aquifer and the underlying aquifers (Cockfield and Sparta aquifers) was small. The average annual net flow for the simulation period for the entire Delta was about 0.2 cubic foot per second downward from the alluvial aquifer into the underlying aquifers. The small net interchange of flow at the lower boundary is attributed to small water-level differences between the alluvial aquifer and the underlying units over most of the Delta, and the low permeability of sediments separating the alluvial aquifer and the underlying aquifers over a large part of the Delta. The area where flow is upward (recharge) to the alluvial aquifer is predominantly in the eastern part of the Delta. Over much of the eastern part of the Delta, the Sparta and Cockfield aquifers directly underlie the alluvium and have water levels greater than water levels in the alluvial aquifer (fig. 27).

Prior to development of the Cockfield and Sparta aquifers, water levels in the two aquifers were much greater (as much as 50 feet above land surface in the southern part of the Delta (Stephenson and others, 1928)) than today (2000). As a result, much of the Mississippi River alluvial plain was a predevelopment regional discharge area for the Sparta and Cockfield aquifers, and net vertical flow was into the alluvial aquifer (recharge to the alluvial aquifer) from the underlying units. With the development of the Cockfield and Sparta aquifers, water levels in the underlying units decreased, resulting in a decrease in vertical flow and the reversal of net flow between the alluvial aquifer and the underlying units. The current (2000) net discharge from the alluvial aquifer into the underlying units will probably increase with increased development and decreased heads in the Sparta and Cockfield aquifers, but the increased net discharge from the alluvial aquifer probably will not have a substantial effect on the availability of water in the alluvial aquifer (Boswell and others, 1968).

\section{Flow Budget}

The year-to-year flow budget for the Mississippi River alluvial aquifer is extremely variable due to the complexity of the flow system and the fluctuation in agricultural pumpage. Simulation results indicate that the flow budget for any one month or for any one year can vary greatly from the previous month or year. Large volumes of water can be recharged to the alluvial aquifer or discharged from the aquifer depending on the stage of the Mississippi River and the stages of the streams and lakes within the Delta. Model results indicate that areal recharge from precipitation is the greatest source of water for the alluvial aquifer, but varies temporally and spatially. Pumpage for agriculture varies monthly and yearly depending upon the amount and distribution of rainfall. Pumpage is also dependent on the type and annual acreage of crops planted. During the simulation period, lateral recharge from the waterbearing units underlying the Bluff Hills was the most consistent source of water for the alluvial aquifer. If water levels in the water-bearing units underlying the Bluff Hills remain near present levels, then lateral recharge at the eastern edge of the Delta probably will not fluctuate substantially. The small net interchange of vertical flow between the alluvial aquifer and the underlying probably will not fluctuate greatly from the amount simulated unless water levels in the underlying aquifers are severely drawn down through time. Model results indicate that water from aquifer storage fluctuates yearly depending on availability of water from recharge sources and the magnitude and distribution of pumpage. Analysis of volumetric change of water in the alluvial aquifer indicates that a large amount of water is available from aquifer storage.

In order to present a flow budget that would most nearly represent long-term flow conditions in the alluvial aquifer flow system, the average annual flow rates for the 9-year simulation period (1988-96) is presented in figure 28 . These rates represent a window in time relative to historic and possible future hydrologic conditions in the Delta.

Model results indicate that pumpage was the greatest average flow component in the alluvial aquifer flow budget during the simulation period. The average withdrawal of water from the aquifer was 1,965 cubic feet per second (1,270 million gallons per day). Areal recharge from precipitation was the second largest average flow component with 1,365 cubic feet per second of water entering the aquifer through the topstratum. Water supplied from aquifer storage was the third 


\section{EXPLANATION}

Area where water levels in underlying aquifers are greater than water levels in alluvial aquifer

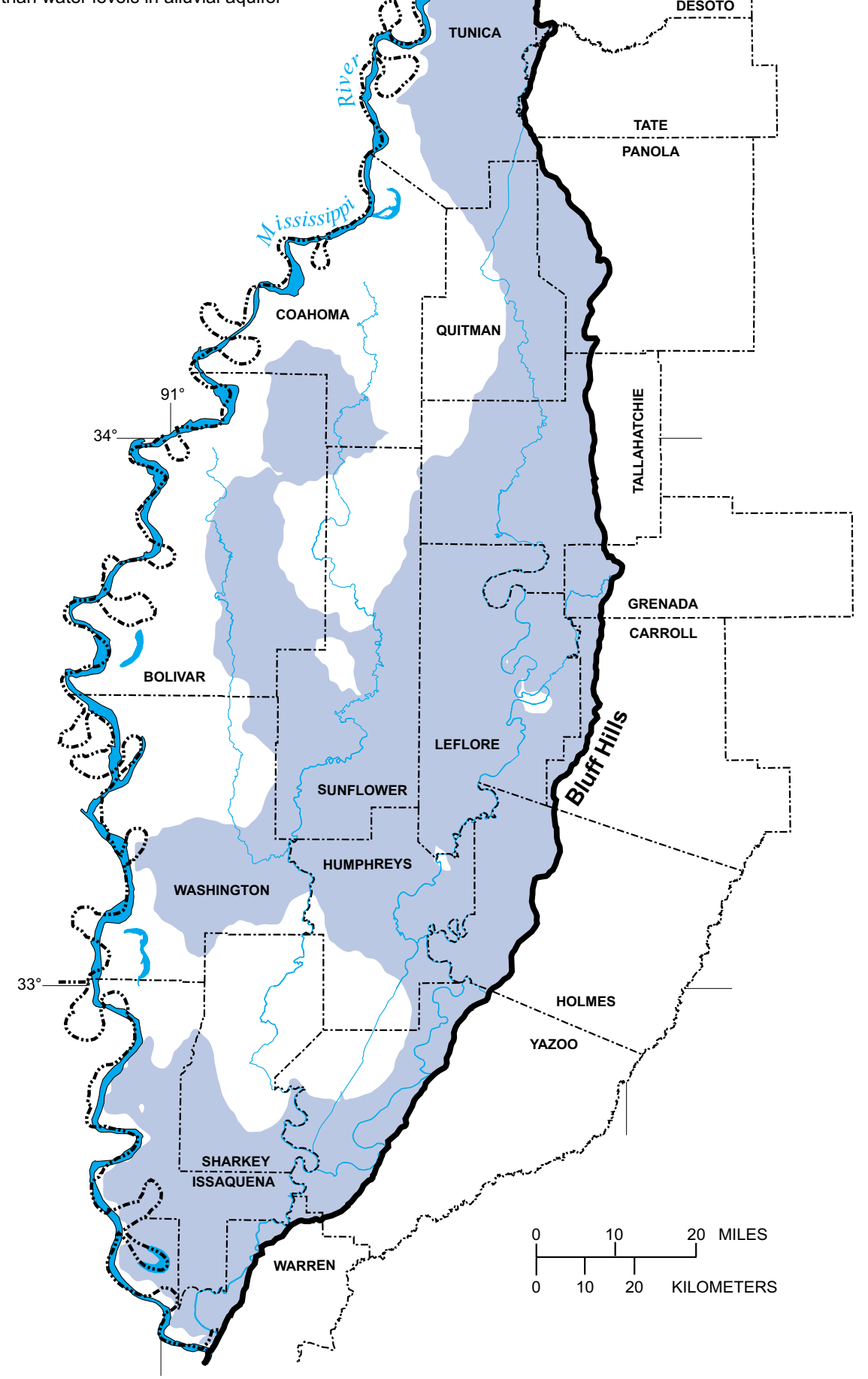

Figure 27. Area where water levels in underlying aquifers are greater than water levels in the Mississippi River alluvial aquifer. 
largest average flow component with 404 cubic feet per second. Recharge from the rivers and lakes within the Delta and lateral recharge from the Bluff Hills were almost equal with 113 and 108 cubic feet per second, respectively. An average of only 0.19 cubic foot per second was vertically discharged from the alluvial aquifer into the underlying aquifers during the simulation period.

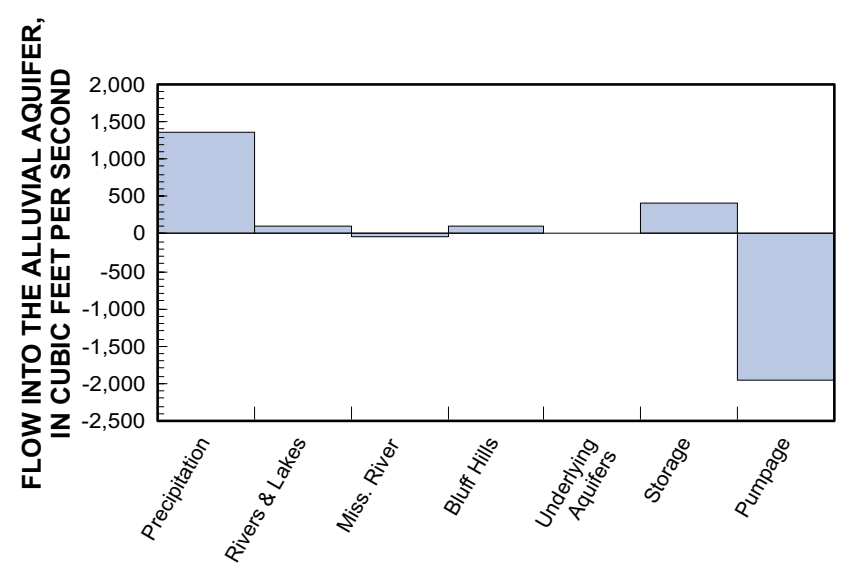

Figure 28. Average flow budget of the Mississippi River alluvial aquifer for the simulation period (1988-96).

\section{MODEL LIMITATIONS}

In order to effectively utilize flow model results, an understanding of the model limitations is essential. The flow model simulates only movement of freshwater through the alluvial aquifer flow system. The model is limited by simplification of the conceptual model of a complex flow system, by space and time discretization effects, by the availability of measurements for estimating spatial variation in hydraulic properties, by limitations in the accuracy of land-surface and waterlevel altitudes, by the availability of water-level measurements in the underlying aquifers, and perhaps most importantly, by limitations in the accuracy of pumpage estimates.

Surface discretization of the study area into a rectangular grid of 1-mile square cells and vertical discretization of the alluvial aquifer into one layer forced an averaging of hydraulic properties. Each active cell represents a homogeneous block of some volumetric average of the aquifer medium. Each cell has a unique layer thickness determined by estimating aquifer thickness using drillers and geophysical logs from several thousand wells in the Delta, but a lack of hydraulic property measurements forced using uniform hydraulic conductivity, specific yield, and storage coefficient val- ues. Discretization of time to 30.4 days for each stress period required using monthly average pumpage rates and monthly average stages for the Mississippi River and the streams and lakes within the Delta. Water levels for the aquifers underlying the alluvial aquifer and underlying the Bluff Hills were assumed constant for the 9-year simulation period, since published potentiometric maps in the Delta area indicated little change in water levels. If pumpage from the Cockfield and Sparta aquifers is substantially increased, then water levels will decrease and modification to the underlying and eastern boundary heads will be necessary for the model to be representative.

Simplification of the model does not invalidate the model results, but does mean that model results should be interpreted at scales larger than the simulated elemental volume of homogeneous aquifer material. If model projections are made, special care should be taken in estimating the stages of the Mississippi River and the internal streams and lakes. Areal recharge during the calibration period was the largest recharge component, so proper model response is dependent upon reasonable estimates of areal recharge. Model simulation results and volumetric analysis indicate that areal recharge is a function of rainfall, so climatic cycles should be considered when making long-term model projections. One should also consider reviewing underlying and adjacent aquifer heads to allow for proper representation for long-term projections. Because pumpage (the largest flow component during the simulation period) will probably increase, consideration should be given to establishing a technically sound, intensive water-use data-collection program in the Delta to complement the long-term intensive waterlevel measuring effort that has been ongoing in the Delta since 1980.

The longer the validation period of the model, the greater the probability of generating reliable model results. Model projections probably should not exceed the length of the calibration period, and the model should be periodically validated with updated data. Keeping the model as current as possible with the latest hydrologic information increases the length of the validation period and enhances the model's capability to generate realistic projection results. Because the alluvial aquifer flow system is sensitive to hydrologic variables that are directly influenced by climatic and economic conditions both within and outside the Delta, one must cautiously select projected hydraulic parameter values for model input, and carefully analyze the 
model results before formulating long-term waterresource management decisions.

\section{SUMMARY}

The Mississippi River alluvial aquifer underlies a 7,000-square-mile area of the Mississippi River alluvial plain in northwestern Mississippi locally known as the Delta. Farming and farm-related businesses are the major sources of income in the Delta. The Delta is a lens-shaped area with little topographic relief that slopes about 0.5 foot per mile from the MississippiTennessee border to near Vicksburg, Mississippi. The climate in the Delta is humid subtropical, and the area receives an average of about 52 inches of precipitation annually. The alluvial aquifer is the most heavily pumped aquifer in Mississippi and supplies most of the water used for agriculture and industry in the Delta. In 1995, the U.S. Geological Survey began a study to better understand the hydrogeology of the alluvial aquifer and to construct a computer model of the alluvial aquifer flow system.

The Mississippi River alluvial aquifer flow system is dynamic and complex in regard to changes in recharge and natural discharge in response to fluctuations in hydrologic and climatic conditions. The aquifer is recharged by the Mississippi River and internal rivers and lakes when at their high stages, by precipitation, by underlying aquifers, and by laterally adjacent aquifers underlying the Bluff Hills. The alluvial aquifer discharges water to the Mississippi River and internal rivers and lakes when surface-water stages fall below the water level in the alluvial aquifer.

The alluvial aquifer consists of sand and gravel deposits of Quaternary age. The average thickness of the alluvium in the Delta is about 135 feet. The various combinations of sand, silts, and clays that occur near the surface of the alluvial plain make up a low permeability topstratum. The topstratum averages about 25 feet in thickness and overlies most of the Delta. The sand and gravel of the alluvium that make up the alluvial aquifer averages about 110 feet in thickness. Tertiary-age deposits underlie the alluvial aquifer and dip to the west and southwest toward the axis of the Mississippi embayment. The Cockfield and Sparta aquifers underlie the alluvial aquifer and are two of the major drinking-water supply aquifers in Mississippi.

The Mississippi River and the Bluff Hills are the lateral flow boundaries of the alluvial aquifer. The topstratum and the deposits that separate the alluvial aqui- fer from the underlying water-bearing units are the top and bottom flow boundaries of the alluvial aquifer. Hydraulic conductivity of the alluvial aquifer, determined from aquifer tests, ranges from 130 to 400 feet per day, and storage coefficients range from 0.0003 to 0.016. Laboratory tests of aquifer material indicate that specific yield ranges from 0.27 to 0.38 . Prior to extensive development, water levels in the alluvial aquifer were between 10 and 20 feet below land surface. During fall 1999, the average water level in the aquifer was about 24.6 feet below land surface. During fall 1999, the alluvial aquifer had the least volume of water since fall 1980 with an average of about 20,690 acre-feet per square mile.

Water in the alluvial aquifer is generally well suited for irrigation, but less suited for municipal use and some industrial uses. The water is commonly a hard, calcium bicarbonate type with appreciable amounts of manganese and dissolved iron.

A modular three-dimensional finite-difference ground-water flow model of the alluvial aquifer was constructed using the U.S. Geological Survey model code MODFLOW. The 1-square-mile cell-size model was calibrated and verified using spring and fall observed water levels from January 1988 through December 1996. The average root-mean-square error of model-generated water levels compared to measured water levels was 4.55 feet. The values of the calibration-derived, aquifer hydraulic parameters are as follows: hydraulic conductivity, 425 feet per day; specific yield, 0.32; and storage coefficient, 0.016; all assumed uniform throughout the aquifer.

The model showed that under average rainfall conditions, areal recharge from precipitation is the greatest source of recharge to the aquifer, with a simulated annual average of about 2.6 inches per year from 1988 through 1996. Model results indicated that an average of 404 cubic feet per second of water was removed from aquifer storage during the simulation period. The model indicated that the next greatest sources of water were the internal streams and lakes, and the aquifers underlying the Bluff Hills with an average recharge rate during the simulation period of 113 and 108 cubic feet per second, respectively.

Although the model indicated that the alluvial aquifer received large volumes of water from the Mississippi River when the river was at high stage, the model also showed that the alluvial aquifer discharged large volumes of water to the river when the river was at low stage, resulting in a small net flow for the simulation 
period between the river and the aquifer. Model results indicated that the net flow between the alluvial aquifer and the underlying Cockfield and Sparta aquifers also was small. The average annual pumpage rate for the simulation period was about 1,270 million gallons per day with most of the withdrawal for rice and catfish production in the central part of the Delta.

Understanding the conceptual model is essential to effectively utilize the model results. The computer model is a simplification of a complex flow system, therefore, potential users need to be aware of and understand the limitations of the model. The model's capability to generate realistic long-term projection results would be enhanced by lengthening the validation period by periodically updating the model with current hydrologic information. 


\section{SELECTED REFERENCES}

Arthur, J.K., 1994, Thickness of the upper and lower confining units of the Mississippi River alluvial aquifer in northwestern Mississippi: U.S. Geological Survey Water-Resources Investigations Report 94-4172, 1 sheet.

1995, Changes in the volume of water in the Mississippi River alluvial aquifer in the Delta, northwestern Mississippi, 1980-94: U.S. Geological Survey Water-Resources Investigations Report 95-4127, $12 \mathrm{p}$.

Arthur, J.K., and Strom, E.W., 1996, Thickness of the Mississippi River alluvium and thickness of the coarse sand and gravel in the Mississippi River alluvium in northwestern Mississippi: U.S. Geological Survey Water-Resources Investigations Report 96-4305, 1 sheet.

Arthur, J.K., and Taylor, R.E., 1998, Ground-water flow analysis of the Mississippi embayment aquifer system, south-central United States: U.S. Geological Survey Professional Paper 1416-I, 148 p.

Bicker, A.R., Jr., 1969, Geologic map of Mississippi: Mississippi Geological Survey, 1 sheet.

Boswell, E.H., Cushing, E.M., and Hosman, R.L., 1968, Quaternary aquifers in the Mississippi Embayment, with a discussion of Quality of the water, by H.G. Jeffery: U.S. Geological Survey Professional Paper 448-E, 15 p.

Brown, G.F., 1947, Geology and artesian water of the alluvial plain in northwestern Mississippi: Mississippi Geological Survey Bulletin $65,424 \mathrm{p}$.

Cushing, E.M., Boswell, E.H., and Hosman, R.L., and others, 1970, Availability of water in the Mississippi embayment: U.S. Geological Survey Professional Paper 448-A, 13 p.

Cushing, E.M., Boswell, E.H., and Hosman, R.L., 1964, General geology of the Mississippi embayment: U.S. Geological Survey Professional Paper 448-B, $28 \mathrm{p}$.

Dalsin, G.J., 1978, The Mississippi River valley alluvial aquifer in Mississippi: U.S. Geological Survey Water-Resources Investigations Report 78-106, 1 sheet.

Darden, Daphne, 1986, Potentiometric map of the Cockfield aquifer in Mississippi, fall 1984: U.S. Geological Survey Water-Resources Investigations Report 86-4042, 1 sheet.

1987, Potentiometric map of the Sparta aquifer in Mississippi, fall 1984: U.S. Geological Survey Water-Resources Investigations Report 86-4206, 1 sheet.

Fenneman, N.M., 1938, Physiography of the eastern United States: McGraw-Hill, 714 p.

Fisk, H.N., 1944, Geological investigation of the alluvial valley of the lower Mississippi River: U.S. Department of Army, Mississippi River Commission, 78 p.

Gandl, L.A., 1979, The Oligocene aquifer system in Mississippi: U.S. Geological Survey Water-Resources Investigations Report 79-28, 1 sheet.

Goldsmith, G.D.S., 1993, Potentiometric-surface map, October through December 1988, and water-level change map, 1983-88, of the Mississippi River alluvial aquifer in northwestern Mississippi: U.S. Geological Water-Resources Investigations Report 92-4176, 1 sheet.

Harbeck, G.E., Jr, Golden, H.G., and Harvey, E.J., 1961, Effect of irrigation withdrawals on stage of Lake Washington, Mississippi: U.S. Geological Survey Water-Supply Paper 1460-I, 388 p.

Harvey, E.J., 1956, Records of wells in the alluvium in northwestern Mississippi: U.S. Geological Survey Bulletin 56-1, 130 p.

Heath, R.C., 1983, Basic ground-water hydrology: U.S. Geological Survey Water-Supply Paper 2220, 24 p.
Heimes, F.J., Ferrigno, C.F., Gutentag, E.D., Luckey, R.R. Stephens, D.M., 1987, Comparison of irrigation pumpage with change in ground-water storage in the High Plains aquifer in Chase, Dundy, and Perkins Counties, Nebraska, 1975-83: U.S. Geological Survey Water-Resources Investigations Report 87-4044, 34 p.

Hosman, R.L., Long, A.T. Lambert, T.W., and others, 1968, Tertiary aquifers in the Mississippi embayment, with discussions of Quality of water, by H.G. Jefferies: U.S. Geological Survey Professional Paper 448-D, 29 p.

Jennings, S.P., 2001, Preliminary report on the hydrogeology of the Tertiary aquifers in the Alluvial Plain region of northwestern Mississippi - subcrop geologic map and cross sections: Mississippi Department of Environmental Quality, Office of Land and Water Resources Open-File Report OLWR 01-101, 3 sheets.

Krinitzsky, E.L., and Wire, J.C., 1964, Ground water in the alluvium of the lower Mississippi valley (upper and central areas): U.S. Army Corps of Engineers Waterways Experiment Station, TR3-658, v. 1 and 2, 400 p.

Lamonds, A.G., and Kernodle, J.M., 1984, Potential ground-water level changes in the Mississippi River alluvial aquifer in response to proposed navigation improvements on the Yazoo River in Mississippi: U.S. Geological Survey Water-Resources Investigations Report 84-4039, $65 \mathrm{p}$

Leake, S.A., 1997, Modeling ground-water flow with MODFLOW and related programs: U.S. Geological Survey Fact Sheet FS-121-97, 4 p.

Lower Mississippi Regional Comprehensive Study, 1974, Regional climatology hydrology and geology: aapp C, v. I, 279 p.

McDonald, M.G., and Harbaugh, A.W., 1988, A modular three-dimensional finite-difference ground-water flow model: Techniques of Water-Resources Investigations of the U.S. Geological Survey, Chapter A1, Book 6, 586 p.

Newcome, Roy, Jr., 1976, The Sparta aquifer system in Mississippi: U.S. Geological Survey Water-Resources Investigations Report 76-7, 3 sheets.

Oakley, W.T., and Burt, D.E.,Jr., 1994a, Potentiometric-surface map of the Cockfield aquifer in Mississippi, October through November 1989: U.S. Geological Survey Water-Resources Investigations Report 93-4202, 1 sheet. 1994b, Potentiometric-surface map of the Sparta aquifer in Mississippi, October through December 1989: U.S. Geological Survey Water-Resources Investigations Report 94-4048, 1 sheet.

Slack, L.J., and Darden, Daphne, 1991, Summary of aquifer tests in Mississippi, June 1942 through May 1988: U.S. Geological Survey Water-Resources Investigations Report 90-4155, 40 p.

Spiers, C.A., 1977, The Cockfield aquifer in Mississippi: U.S. Geological Survey Water-Resources Investigations Report 77-17, 3 sheets.

Stephenson, L.W., Logan, W.N., and Waring, G.A., 1928, The groundwater resources of Mississippi: U.S. Geological Survey Paper $576,515 \mathrm{p}$.

Sumner, D.M., and Wasson, B.E., 1990, Geohydrology and simulated effects of large ground-water withdrawals on the Mississippi River alluvial aquifer in northwestern Mississippi: U.S. Geological Survey Water-Supply Paper 2292, 60 p.

Taylor, R.E., and Thomson, F.H., 1971, Water for industry and agriculture in Washington County, Mississippi: Delta Council Bulletin, $64 \mathrm{p}$.

Wasson, B.E., 1980, Sources for water supplies in Mississippi: Mississippi Research and Development Center Bulletin, 112 p. 